B O N N E V I L L E P O W E R A D M I N I S T R A T I O

Monitoring the Migrations of Wild Snake River Spring/Summer Chinook Salmon Juveniles

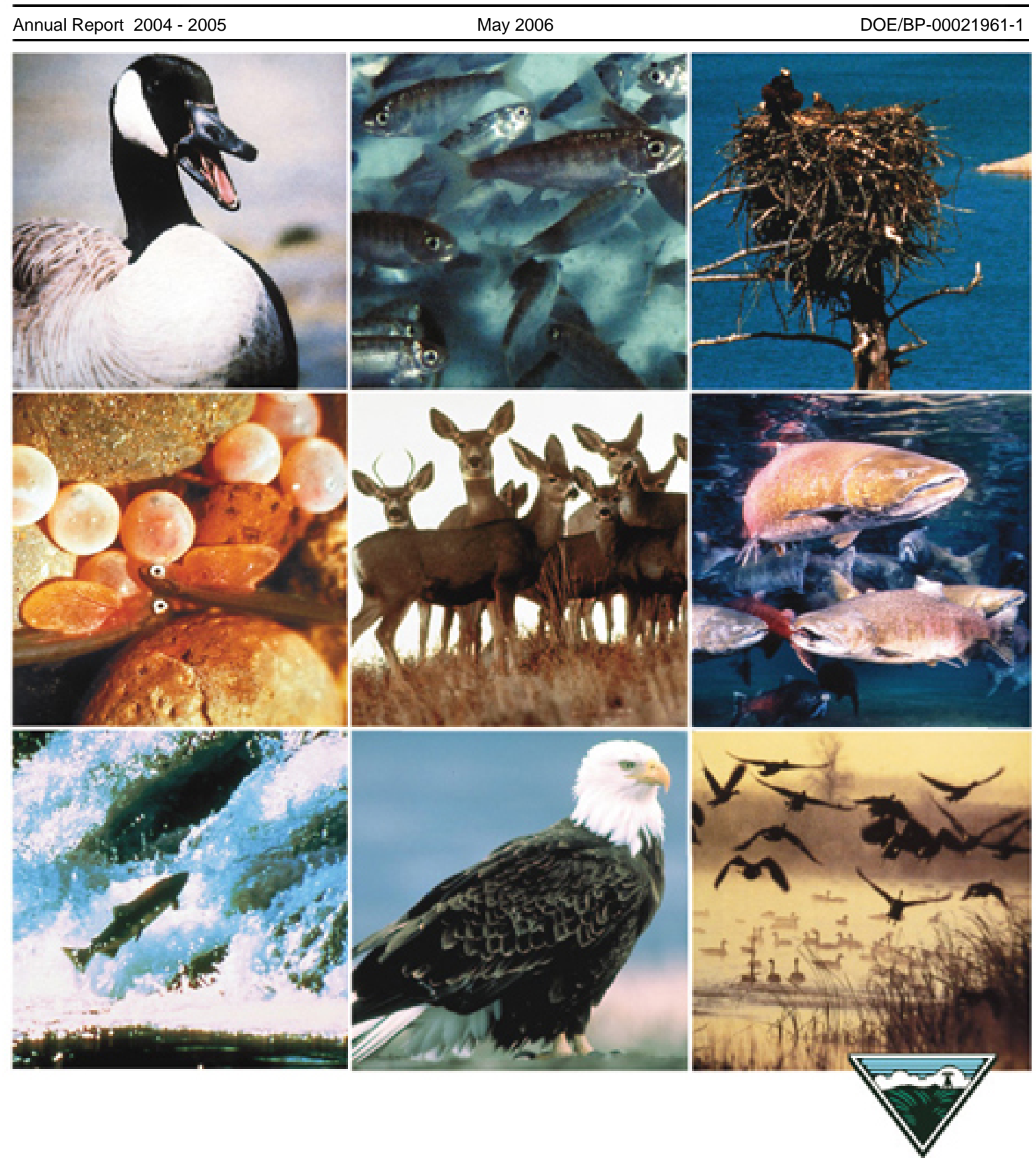


This Document should be cited as follows:

Achord, Stephen, Benjamin Sandford, Eric Hockersmith, Jacob Hodge, Kenneth McIntyre, Neil Paasch, Lisa Crozier, John Williams, "Monitoring the Migrations of Wild Snake River

Spring/Summer Chinook Salmon Juveniles", 2004-2005 Annual Report, Project No. 199102800, 105 electronic pages, (BPA Report DOE/BP-00021961-1)

\author{
Bonneville Power Administration \\ P.O. Box 3621 \\ Portland, OR 97208
}

This report was funded by the Bonneville Power Administration (BPA), U.S. Department of Energy, as part of BPA's program to protect, mitigate, and enhance fish and wildlife affected by the development and operation of hydroelectric facilities on the Columbia River and its tributaries. The views in this report are the author's and do not necessarily represent the views of BPA. 


\title{
Monitoring the Migrations of Wild Snake River Spring/Summer Chinook Salmon Juveniles, 2004-2005
}

Stephen Achord, Benjamin P. Sandford, Eric E. Hockersmith, Jacob M. Hodge, Kenneth W. McIntyre, Neil N. Paasch, Lisa G. Crozier, and John G. Williams

\author{
Report of research by \\ Fish Ecology Division \\ Northwest Fisheries Science Center \\ National Marine Fisheries Service \\ National Oceanic and Atmospheric Administration \\ 2725 Montlake Boulevard East \\ Seattle, Washington 98112-2097 \\ for \\ U.S. Department of Energy \\ Bonneville Power Administration \\ Division of Fish and Wildlife \\ P.O. Box 3621 \\ Portland, Oregon 97208-3621 \\ Project 1991-028-00 \\ Contract No. 00021961
}

May 2006 


\section{EXECUTIVE SUMMARY}

This report provides results from an ongoing project to monitor the migration behavior and survival of wild juvenile spring/summer Chinook salmon in the Snake River Basin. Data reported is from 2005 detections of fish tagged in Idaho by the National Marine Fisheries Service in summer 2004 and of fish tagged in Oregon during 2004 by the Oregon Department of Fish and Wildlife. Our analyses include arrival timing and estimated survival to Lower Granite Dam. Principal results from tagging and interrogation during 2004-2005 are listed below:

1) In July and August 2004, we tagged 19,886 wild Chinook salmon parr with passive integrated transponder (PIT) tags. Fish were collected and released in 15 Idaho streams.

2) Average overall observed mortality from collection, handling, tagging, and after a 24-h holding period was $0.8 \%$.

3) Of 2,511 Chinook salmon parr tagged and released in Valley Creek, 14.2\% (357) were detected at two instream PIT-tag monitoring systems in lower Valley Creek from late summer 2004 to the following spring 2005. Of these, $77.3 \%$ were detected in late summer/fall, $14.0 \%$ in winter, and $8.7 \%$ in spring. Estimated parr-to-smolt survival to Lower Granite Dam was $10.9 \%$ for the late summer/fall group, $22.7 \%$ for the winter group, and $32.9 \%$ for the spring group. An estimated 41.5 to $46.4 \%$ of all tagged parr survived to migrate out of Valley Creek, and their estimated survival to Lower Granite Dam was 13.9\%. Overall parr-to-smolt survival to the dam for all tagged parr from this stream was estimated at $5.9 \%$. Development and improvement of instream PIT-tag monitoring systems continued throughout 2004 and 2005.

4) At Little Goose Dam in 2005, length and weight was measured for 656 recaptured fish from 15 Idaho streams. Fish had grown an average of $44.5 \mathrm{~mm}$ in length and $9.6 \mathrm{~g}$ in weight over an average of $282 \mathrm{~d}$. Their mean condition factor declined from 1.24 at release (parr) to 0.96 at recapture (smolt).

5) Fish that were larger at release were detected at a significantly higher rate the following spring and summer than their smaller cohorts $(P<0.001)$.

6) Fish that arrived at Lower Granite Dam in April and May were significantly larger at release than fish that arrived after May $(P<0.001)$. 
7) In 2005, peak detections at Lower Granite Dam of all fish tagged as parr during summer 2004 (from the 15 streams in Idaho and 4 streams in Oregon) occurred during low flows of $60.4 \mathrm{kcfs}$ on 5 May. The 10th, 50th, and 90th percentile passage dates were 25 April, 7 May, and 24 May, respectively.

8) Estimated parr-to-smolt survival to Lower Granite Dam for Idaho and Oregon streams combined averaged 8.4\% (range 3.7-13.3\% depending on stream of origin). This was the second lowest average survival rate measured in the last 13 years. The low survival rate may have been related to high parr densities in 2004, which resulted from a comparatively large number of wild spawners in 2003.

In 2005, the 50th and 90th percentile passage dates of wild fish at Lower Granite Dam occurred in early and late May, respectively. Although climate conditions were cool and wet, flows were considered low until mid-May 2005. We again concluded that the annual migration of these wild stocks is driven by complex interrelationships involving several factors. 


\section{CONTENTS}

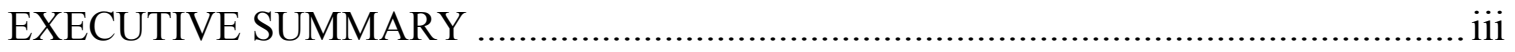

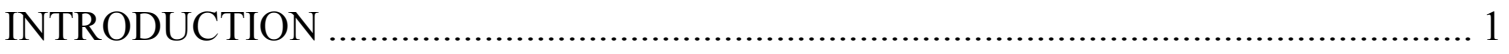

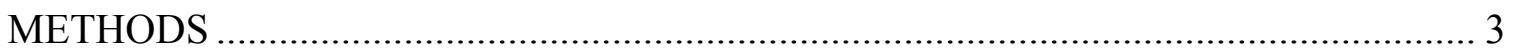

Fish Collection and Tagging .................................................................... 3

Interrogation at Instream PIT-Tag Monitors.................................................... 3

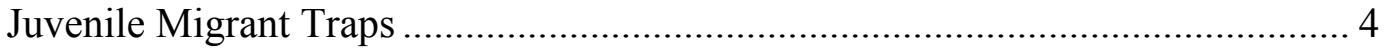

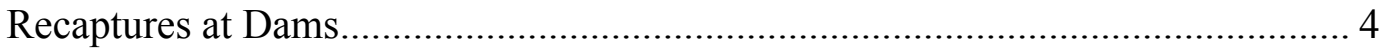

Interrogation at Dams and in the Columbia River Estuary ............................... 6

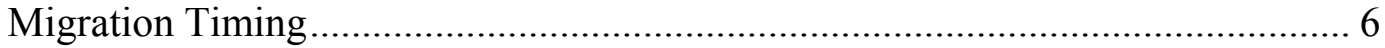

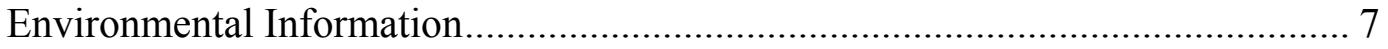

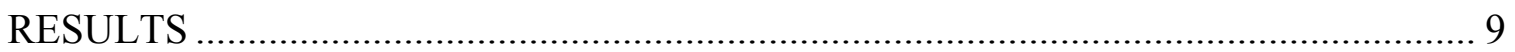

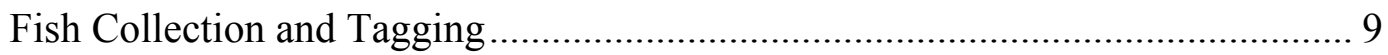

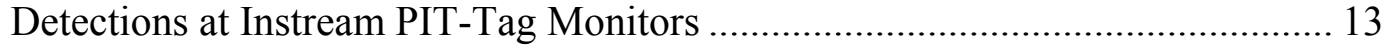

Recaptures at Traps and Little Goose Dam ..................................................... 15

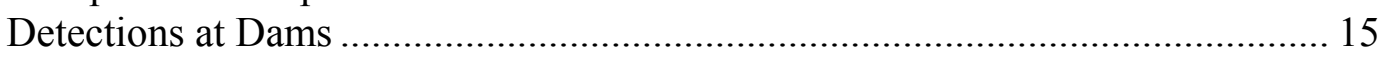

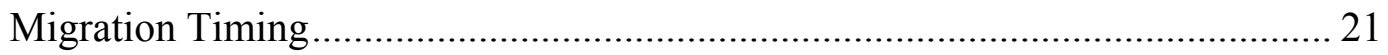

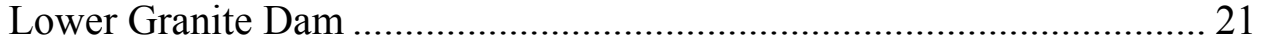

Comparison with Flows ........................................................................ 26

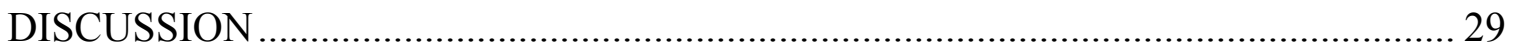

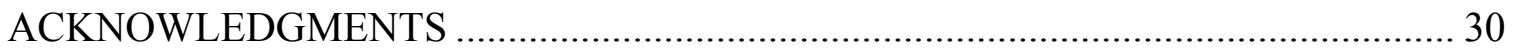

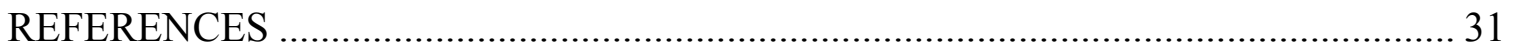

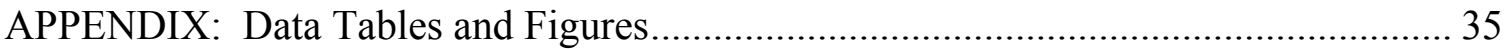




\section{INTRODUCTION}

This report provides information on wild Chinook salmon tagged as parr using passive integrated transponder (PIT) tags. Fish were tagged in late summer 2004 and subsequently monitored through spring 2005. Survival and migration timing to Lower Granite Dam is reported, as well as interrogation data from several other PIT-tag monitoring sites throughout the Snake and Columbia Rivers. This research continues studies that began in 1991 with funding from the Bonneville Power Administration. Results from previous study years were reported by Achord et al. (1994, 1995a,b, 1996a, 1997, 1998, 2000, 2001a,b, 2002, 2003, 2004, 2005). The goals of this ongoing study are:

1) Characterize the migration timing and estimate parr-to-smolt survival of different stocks of wild Snake River spring/summer Chinook salmon smolts at Lower Granite Dam.

2) Determine whether consistent migration patterns are apparent.

3) Determine what environmental factors influence these migration patterns.

4) Characterize the migrational behavior and estimate survival of different wild juvenile fish stocks as they emigrate from their natal rearing areas.

This study provides critical information for recovery planning of wild stocks listed as endangered or threatened under the U.S. Endangered Species Act.

During 2004-2005 in the Salmon River Basin, Idaho, we collected data from five monitoring stations that measured water temperature, dissolved oxygen, specific conductance, turbidity, water depth, and $\mathrm{pH}$. We also collected weather data from three stations and stream flow data from two stations for the Baseline Environmental Monitoring Program. These environmental data can be compared with parr/smolt migration, survival, and timing data to help to discern whether patterns or characteristic relationships exist that may help in recovery planning for threatened stocks. 


\section{METHODS}

\section{Fish Collection and Tagging}

National Marine Fisheries personnel tagging fish in Idaho streams during 2004 used the safe handling methods developed for wild fish during this study. These handling methods are detailed in Matthews et al. (1990) and in previous reports from this study (Achord et al. 1994, 1995a,b, 2003, 2004).

The Oregon Department of Fish and Wildlife (ODFW) PIT tagged wild Chinook salmon parr in the Grande Ronde and Imnaha River drainages in northeast Oregon in 2004. All tagging, detection, and migration timing information for theses fish will be reported by ODFW. However, in agreement with ODFW, we report the timing and overall estimated survival to Lower Granite Dam of fish from these Oregon streams.

\section{Interrogation at Instream PIT-Tag Monitors}

Until recently, the opportunities to monitor migrating PIT-tagged wild juvenile fish were limited to a few manually operated traps in streams or rivers, the PIT-tag monitors within juvenile fish bypass systems at dams, and the PIT-tag detector trawl operated in the upper Columbia River estuary. In an effort to detect fish closer to tagging sites, we began development of passive instream PIT-tag monitoring systems in Valley Creek in 2002.

We placed instream monitoring systems at two sites located $1.6 \mathrm{~km}$ apart. Development of these systems continued throughout 2003, 2004, and 2005, and details about the equipment used was described by Achord et al. (2004, 2005). In summary, both systems were set up to automatically interrogate, store, and transmit data to the PIT Tag Information System (PTAGIS; PSMFC 1996) in the same manner as interrogation systems at the dams. Here we report data collected at the instream monitors from August 2004 through July 2005. 


\section{Juvenile Migrant Traps}

Some fish PIT tagged as parr in natal rearing areas are subsequently collected at migrant traps (Figure 1). During fall 2004 and spring 2005, juvenile migrant fish traps were operated at Knox Bridge on the South Fork of the Salmon River, on Lake Creek, near Chinook Campground on the Secesh River, on Marsh Creek, and near the Sawtooth Hatchery on the upper Salmon River. Also during spring 2005, juvenile migrant fish traps were operated on the lower Salmon River near Whitebird, Idaho, and on the Snake River at Lewiston, Idaho. Traps were operated by the Nez Perce Tribe and the Idaho Department of Fish and Game.

Generally, fish at these traps were anesthetized, scanned for PIT tags, and then measured for length and weight. Upon recovery from the anesthetic, all fish were released back to the streams or rivers.

\section{Recaptures at Dams}

While collecting and PIT tagging fish at dams for various studies, NMFS and other personnel occasionally encounter wild fish that are already PIT tagged. In such cases, biological data are usually collected from these fish. To increase sample sizes for parr-to-smolt growth information on previously PIT-tagged wild fish, in 2005 we continued efforts begun in 2001 to utilize the PIT-tag separation-by-code system (Downing et al. 2001) at Little Goose Dam. The system was programmed to separate up to a maximum of 100 wild fish from each stream so that we could take length and weight measurements from a sample of fish. All fish that were separated at the dam were handled using water-to-water transfers and other best handling practices. After handling, all tagged and untagged fish were returned to the bypass system for release below the dam.

In addition to length and weight measurements on these wild smolts at Little Goose Dam, a Fulton-type condition factor (CF) was calculated as

$$
\mathrm{CF}=\frac{\text { weight }(\mathrm{g})}{\text { length }(\mathrm{mm})} \times 10^{5}
$$

Condition factors were calculated for these fish both at release and recapture. 


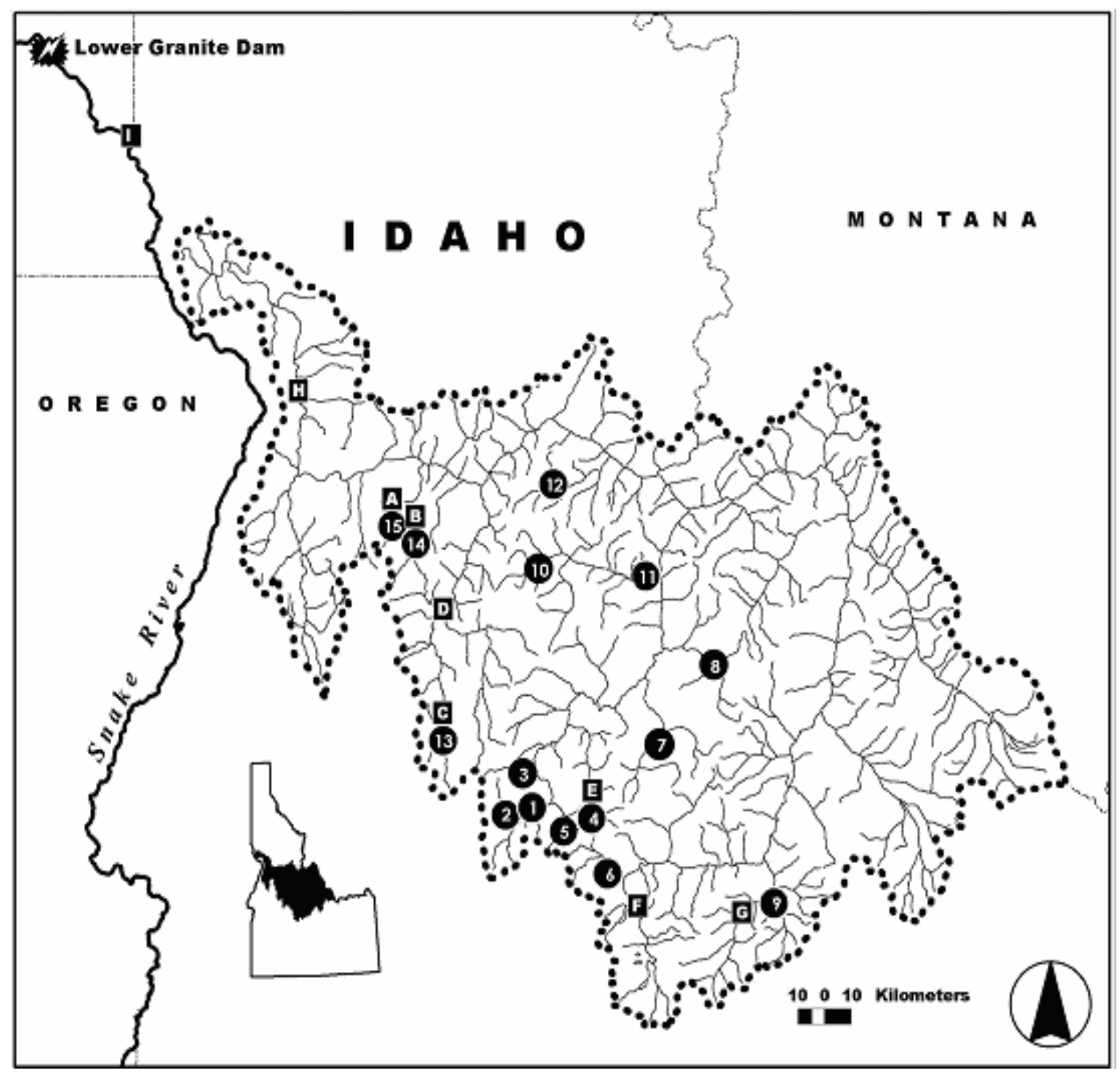

Figure 1. Wild spring/summer Chinook salmon parr were PIT tagged during 2004 in the following streams:

1-Bear Valley Creek

2-Elk Creek

3-Sulphur Creek

4-Marsh Creek

5-Cape Horn Creek
6-Valley Creek

7-Loon Creek

8-Camas Creek

9-Herd Creek

10-Big Creek (upper)
11-Big Creek (lower)

12-W.F. Chamberlain/Chamberlain Creek

13-South Fork Salmon River

14-Secesh River

15-Lake Creek

Juvenile migrant fish traps shown above are as follows:

A-Lake Creek Trap

B-Secesh River Trap

C-South Fork Salmon River

(Knox Bridge) Trap
D-Lower S.F. Salmon River Trap

E-Marsh Creek Trap

F-Sawtooth Trap
G-East Fork Salmon River Trap

H-Salmon River Trap

I-Snake River Trap 


\section{Interrogation at Dams and in the Columbia River Estuary}

A portion of wild Chinook salmon PIT tagged as parr in summer 2004 survived over winter to migrate downstream on the Snake and Columbia Rivers during spring and summer 2005. As migrating smolts, these fish encountered eight dams on the lower Snake and Columbia River. Of these eight, the following seven dams were equipped with smolt collection or PIT-tag interrogation systems: Lower Granite, Little Goose, Lower Monumental, and Ice Harbor Dams on the Snake River; and McNary, John Day, and Bonneville Dams on the Columbia River.

At each of these seven dams, smolts passed via the spillway, juvenile bypass diversion system, or turbines. All smolts that were guided into juvenile bypass systems were electronically monitored for PIT tags. The PIT-tag interrogation systems were the same as those described by Prentice et al. (1990). Dates and times to the nearest second were automatically recorded on a computer as PIT-tagged fish passed each detector, and detection data were transferred once daily to PTAGIS (PSMFC 1996).

Tagged fish were also monitored by a surface trawl detector operated in the upper Columbia River estuary (approximately $150 \mathrm{~km}$ downstream from Bonneville Dam). The trawl system and its operation are described by Ledgerwood et al. (2004).

\section{Migration Timing}

We monitored within-season migration timing based on daily detection numbers at Lower Granite Dam of all wild PIT-tagged Chinook salmon smolts. Detection numbers were expanded based on estimated daily detection probabilities, which were calculated using the methods of Sandford and Smith (2002). This method provided daily estimates of the number of PIT-tagged wild spring/summer Chinook salmon smolts that passed the dam. Daily estimates were then pooled to obtain a yearly survival estimate, which we compared to survival estimates from previous years.

Migration timing at Lower Granite Dam was calculated by totaling the (expanded) number of detections in 3-d intervals and dividing by total detections during the season. This method was applied to detection data for fish from combined streams. 
There was no straightforward way of comparing Lower Granite Dam arrival statistics (10th, median, and 90th percentiles) between streams to find statistically significant differences. We used an approach analogous to analysis of variance with multiple comparisons. Bootstrap methods were used to calculate estimates of the standard error for each statistic (Efron and Tibshirani 1993). A "representative" estimate of variance for each statistic was then calculated as the median of the standard errors (SEs) for fish from all 19 streams. This method assumed that the timing of passage percentiles had similar distributions among streams. The Student-Newmann-Keuls (SNK) multiple comparison method was used to make comparisons between streams for each statistic $(\alpha=0.05$; Petersen 1985).

We also examined the migration timing at Lower Granite Dam of individual populations over a period of years to determine similarities or differences between years and between populations. We chose populations with 8 or more years of timing data for these analyses. Comparisons of the 10th, 50th, and 90th percentile passage dates were made among 18 streams using a two-factor analysis of variance (ANOVA). "Year" was considered a random factor and "stream" a fixed factor. Residuals were visually examined to assess normality. Treatment means were compared using Fisher's least significant difference procedure (Peterson 1985). Statistical significance was set at $\alpha=0.05$.

\section{Environmental Information}

In 2004-2005, we collected hourly measurements of water temperature, dissolved oxygen, specific conductance, turbidity, water depth, and $\mathrm{pH}$ from the following locations: 1) Marsh Creek, 2) Valley Creek, 3) Sawtooth Hatchery in the upper Salmon River, 4) South Fork of the Salmon River (Knox Bridge), and 5) Secesh River (near Chinook Campground).

All monitoring systems except the system at Valley Creek were close to juvenile migrant fish traps. The water quality monitor at Valley Creek was located near our instream PIT-tag monitoring system (VC2). Also, we collected weather/climate data from 3 weather stations and stream flows from 2 stations in the Salmon River basin. 


\section{RESULTS}

\section{Fish Collection and Tagging}

From 21 July to 27 August 2004, we collected 30,154 wild Chinook salmon parr in 15 Idaho streams (Figure 1) over a distance of about 33.3 stream kilometers and approximately $346,581 \mathrm{~m}^{2}$ (Table 1; Appendix Table 2). Of these fish, 19,886 were PIT tagged and released back into the streams along with the remaining untagged live fish. Fish were rejected for tagging because of small size, injury, precocious maturation, or because excess numbers of fish had been collected. In addition, some fish were rejected because they were previously tagged, and others were collected for unrelated studies of genetics and marine derived nutrients. Numbers of tagged fish released per stream ranged from 298 in Chamberlain Creek to 2,511 in Valley Creek (Table 1 and Appendix Tables 2 and 3a).

Fork lengths of all collected Chinook salmon parr ranged from 37 to $177 \mathrm{~mm}$ (mean $60.2 \mathrm{~mm}$ ), and weights ranged from 0.5 to $32.0 \mathrm{~g}$ (mean $3.1 \mathrm{~g}$ ). Fork lengths of tagged and released Chinook salmon parr ranged from 47 to $157 \mathrm{~mm}$ (mean $63.2 \mathrm{~mm}$ ) (occasionally fish smaller than $55 \mathrm{~mm}$ are inadvertently tagged), and weights ranged from 1.1 to $13.5 \mathrm{~g}$ (mean $3.2 \mathrm{~g}$; Appendix Table 2). In 2004, collection areas within the streams were further delineated by recording Global Positioning System (GPS) coordinates using Universal Transverse Mercator (UTM) grid (Appendix Table 3b).

Other than Chinook salmon parr, unidentified fry were the most abundant fish observed during collection operations (Table 2). However, the records of non-target fish do not represent total abundances in the collection areas, as we targeted only Chinook salmon and not other coincident species.

Overall mortality associated with collection, tagging, and 24-h holding averaged 0.8\% (Table 3; Appendix Table 4). 
Table 1. Summary of collection, PIT tagging, and release of wild Chinook salmon parr with average fork lengths and weights, approximate distances, and estimated areas sampled in streams of Idaho during July and August 2004.

\begin{tabular}{|c|c|c|c|c|c|c|c|c|}
\hline \multirow[b]{2}{*}{ Tagging location } & \multicolumn{2}{|c|}{ Number of fish } & \multicolumn{2}{|c|}{$\begin{array}{l}\text { Average fish } \\
\text { length }(\mathrm{mm})\end{array}$} & \multicolumn{2}{|c|}{$\begin{array}{c}\text { Average fish } \\
\text { weight }(\mathrm{g})\end{array}$} & \multirow{2}{*}{$\begin{array}{c}\text { Collection area to } \\
\text { mouth of stream } \\
(\mathrm{km})\end{array}$} & \multirow{2}{*}{$\begin{array}{c}\text { Estimated area } \\
\text { sampled in } \\
\text { streams }\left(\mathrm{m}^{2}\right)\end{array}$} \\
\hline & Collected & $\begin{array}{c}\text { Tagged and } \\
\text { released }\end{array}$ & Collected & Tagged & Collected & Tagged & & \\
\hline Bear Valley Creek. & 2,640 & 1,500 & 56.4 & 59.9 & 2.4 & 2.5 & 9,13 , and 14 & 17,140 \\
\hline Elk Creek & 2,098 & 1,471 & 58.4 & 61.1 & 2.9 & 3.0 & $0-4$ & 18,109 \\
\hline Marsh Creek & 2,316 & 1,501 & 60.4 & 64.7 & 3.4 & 3.7 & 11 and 14 & 3,010 \\
\hline Sulphur Creek & 2,086 & 1,157 & 55.7 & 61.3 & 2.9 & 2.9 & $5-7$ & 4,550 \\
\hline Cape Horn Creek & 2,703 & 1,022 & 53.1 & 61.3 & 3.1 & 3.1 & $0-3$ & 30,640 \\
\hline Valley Creek & 4,577 & 2,511 & 57.3 & 63.0 & 2.9 & 3.0 & 4,9 , and 18 & 23,278 \\
\hline Loon Creek & 1,619 & 1,501 & 61.7 & 62.5 & 3.3 & 3.3 & $33-37$ & 29,939 \\
\hline Camas Creek & 1,742 & 1,500 & 60.8 & 62.1 & 3.4 & 3.5 & $22-24$ & 34,129 \\
\hline Herd Creek & 1,818 & 1,559 & 64.9 & 66.8 & 3.8 & 3.9 & $1 \& 3$ & 22,297 \\
\hline Big Creek (upper) & 1,801 & 1,516 & 63.4 & 63.5 & 3.0 & 3.0 & $55-57$ & 24,864 \\
\hline Big Creek (lower) & 393 & 374 & 71.1 & 71.2 & 4.2 & 4.2 & $8-10$ & 16,562 \\
\hline W.F. Chamb. Creek & 1,039 & 1,030 & 66.1 & 66.0 & 3.4 & 3.4 & $1-2$ & 3,120 \\
\hline Chamberlain Creek. & 355 & 298 & 60.0 & 61.0 & 3.0 & 3.0 & $25-26$ & 10,068 \\
\hline S.F. Salmon River & 2,489 & 1,222 & 56.1 & 61.4 & 2.8 & 2.7 & 117 and 123 & 44,047 \\
\hline Secesh River & 1,506 & 1,074 & 59.9 & 62.8 & 2.8 & 2.9 & $25-29$ & 40,787 \\
\hline Lake Creek & 972 & 650 & 58.7 & 62.2 & 2.8 & 3.0 & $1-3$ & 24,041 \\
\hline Totals or averages & 30,154 & 19,886 & 60.2 & 63.2 & 3.1 & 3.2 & 33.3 & 346,581 \\
\hline
\end{tabular}


Table 2. Summary of species other than Chinook salmon parr observed during collection operations in Idaho in July and August 2004. Numbers of steelhead in parentheses were PIT tagged for the Idaho Department of Fish and Game.

\begin{tabular}{|c|c|c|c|c|c|c|c|c|c|c|c|}
\hline$\underline{\text { Streams }}$ & Steelhead & $\begin{array}{c}\text { Tagged } \\
\text { steelhead }\end{array}$ & $\begin{array}{c}\text { Unidentified } \\
\text { fry }\end{array}$ & $\begin{array}{c}\text { Brook } \\
\text { trout }\end{array}$ & $\begin{array}{c}\text { Cutthroat } \\
\text { trout }\end{array}$ & $\begin{array}{l}\text { Bull } \\
\text { trout }\end{array}$ & Sculpin & Dace & Sucker & Whitefish & Shiner \\
\hline Bear Valley Creek & 47 & (9) & 384 & 29 & 0 & 1 & 30 & 55 & 10 & 265 & 0 \\
\hline Elk Creek & 107 & (35) & 72 & 110 & 0 & 0 & 35 & 51 & 21 & 117 & 0 \\
\hline Marsh Creek & 6 & (0) & 193 & 80 & 0 & 0 & 42 & 0 & 0 & 57 & 0 \\
\hline Sulphur Creek & 65 & (9) & 50 & 0 & 1 & 0 & 25 & 0 & 0 & 5 & 0 \\
\hline Cape Horn Creek & 75 & (22) & 96 & 47 & 0 & 4 & 1,068 & 1 & 0 & 0 & 0 \\
\hline Valley Creek & 73 & (43) & 171 & 49 & 0 & 4 & 574 & 416 & 106 & 98 & 142 \\
\hline Loon Creek & 157 & (45) & 1,111 & 0 & 0 & 0 & 412 & 0 & 0 & 19 & 0 \\
\hline Camas Creek & 122 & (56) & 1,973 & 0 & 0 & 1 & 0 & 0 & 0 & 8 & 0 \\
\hline Herd Creek & 88 & (29) & 580 & 0 & 0 & 1 & 490 & 0 & 0 & 8 & 0 \\
\hline Big Creek (upper) & 195 & (27) & 395 & 83 & 0 & 7 & 2,049 & 0 & 0 & 0 & 0 \\
\hline Big Creek (lower) & 145 & $(52)$ & 733 & 0 & 9 & 0 & 34 & 329 & 16 & 0 & 0 \\
\hline W.F. Chamberlain Creek & 68 & (0) & 173 & 0 & 0 & 4 & 13 & 0 & 0 & 30 & 0 \\
\hline Chamberlain Creek & 42 & (0) & 239 & 0 & 0 & 2 & 130 & 0 & 0 & 0 & 0 \\
\hline S. Fork Salmon River & 407 & (101) & 859 & 14 & 0 & 3 & 524 & 16 & 3 & 6 & 0 \\
\hline Secesh River & 97 & (20) & 912 & 22 & 0 & 3 & 139 & 6 & 3 & 1 & 0 \\
\hline Lake Creek & 33 & (12) & 356 & 25 & 0 & 9 & 404 & 0 & 0 & 1 & 0 \\
\hline Totals & 1,727 & $(460)$ & 8,297 & 459 & 10 & 39 & 5,969 & 874 & 159 & 615 & 142 \\
\hline
\end{tabular}


Table 3. Mortality percentages for wild Chinook salmon parr collected and PIT-tagged in Idaho in July and August 2004. Only one tag loss occurred during the 2004 study. The tag was lost from a Big Creek (upper) file.

\begin{tabular}{lccc}
\hline & \multicolumn{3}{c}{ Mortality per stream (\%) } \\
\cline { 2 - 4 } Tagging location & Collection & $\begin{array}{c}\text { Tagging and 24-h } \\
\text { post tagging }\end{array}$ & Overall \\
\hline Bear Valley Creek & 0.3 & 0.1 & 0.4 \\
Elk Creek & 0.7 & 0.0 & 0.7 \\
Marsh Creek & 0.2 & 0.1 & 0.3 \\
Sulphur Creek & 0.1 & 0.1 & 0.1 \\
Cape Horn Creek & 0.6 & 0.1 & 0.7 \\
Valley Creek & 1.3 & 0.2 & 1.4 \\
Loon Creek & 0.6 & 0.1 & 0.6 \\
Camas Creek & 1.7 & 0.1 & 1.8 \\
Herd Creek & 1.0 & 0.0 & 1.0 \\
Big Creek (upper) & 0.4 & 0.0 & 0.4 \\
Big Creek (lower) & 3.3 & 0.3 & 3.6 \\
West Fork Chamberlain Creek & 0.0 & 0.3 & 0.3 \\
Chamberlain Creek & 1.7 & 0.0 & 1.7 \\
South Fork Salmon River & 0.6 & 0.2 & 0.8 \\
Secesh River & 0.6 & 0.1 & 0.7 \\
Lake Creek & 0.5 & 0.0 & 0.5 \\
Totals or averages & 0.7 & & \\
\hline
\end{tabular}




\section{Detections at Instream PIT-Tag Monitors}

From 2 to 4 August 2004, 2,511 wild Chinook salmon parr were collected, PIT tagged, and released in natal rearing areas from 3 to $16 \mathrm{~km}$ above the upper instream PIT-tag monitor in lower Valley Creek (VC1; Table 1). Between 2 August 2004 and 30 June 2005, the two instream monitors (VC1 and VC2) recorded 357 unique detections of these summer-tagged Chinook salmon juveniles (Figure 2). Average downstream travel time for the 29 fish detected at both monitors was $19 \mathrm{~h}$ and $5 \mathrm{~min}$ (range from $11 \mathrm{~h}$ and $54 \mathrm{~min}$ to $12 \mathrm{~d}$ ). Of the 357 unique detections at instream monitors, $276(77.3 \%)$ occurred in late-summer/fall (August to October), 50 (14.0\%) in winter (November to February), and 31 (8.7\%) in spring (March to June; Figure 2). An estimated 41.5 to $46.4 \%$ of all summer-tagged parr survived to migrate from Valley Creek.

Valley Creek Wild Chinook

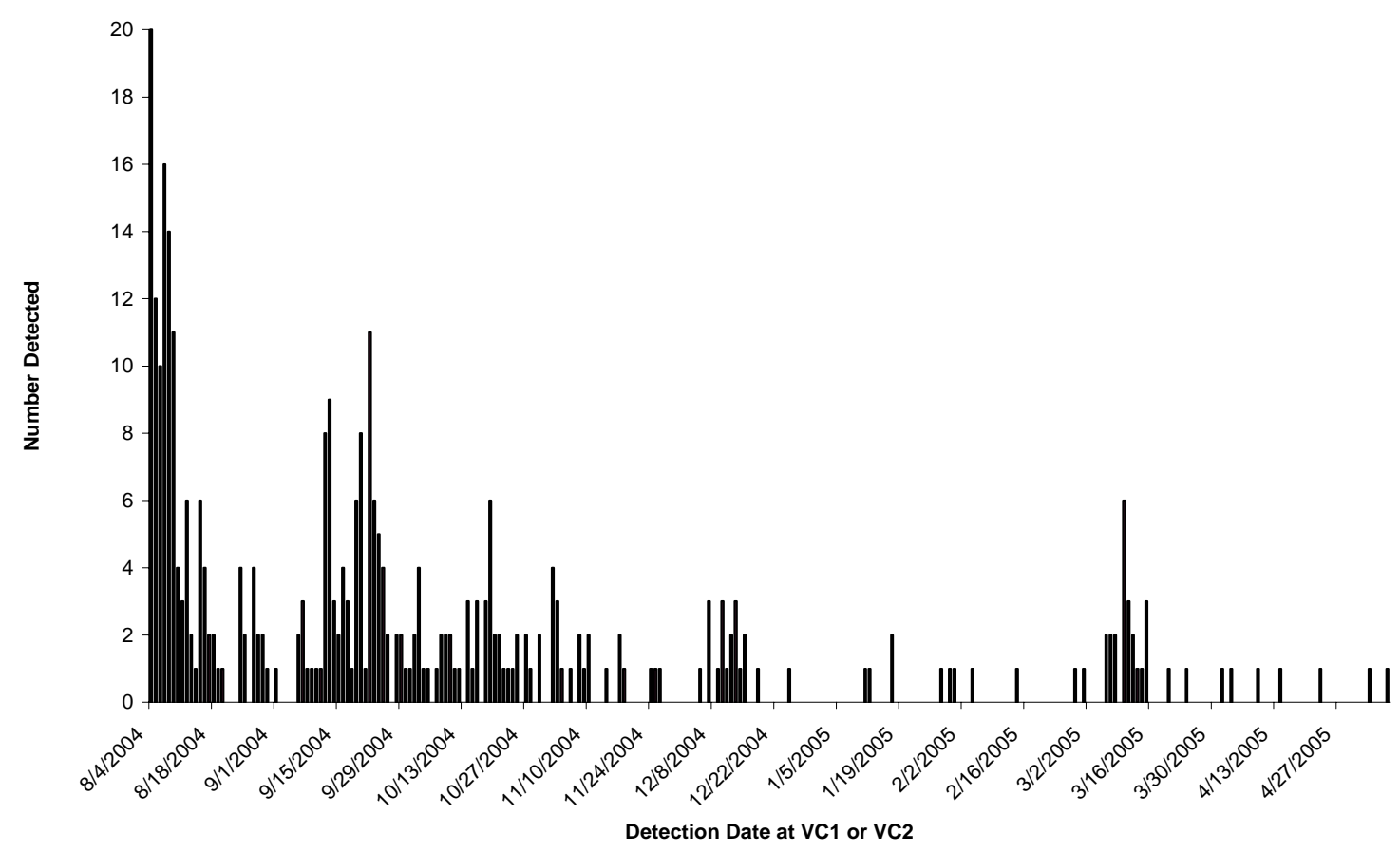

Figure 2. Detections of 357 PIT-tagged wild spring/summer Chinook salmon parr, pre-smolts, and smolts at the upper and lower instream PIT-tag monitoring antennas in lower Valley Creek from August 2004 through June 2005. A total of 2,511 Chinook salmon parr were PIT tagged and released in areas from 3 to 16 kilometers above these antennas from 2 to 4 August 2004. 
Fork lengths and median fork lengths of the 357 fish detected in lower Valley Creek from August 2004 through May 2005 increased from the time of tagging to the time of detection (Figure 3).

MY 2005 Valley Creek Detections

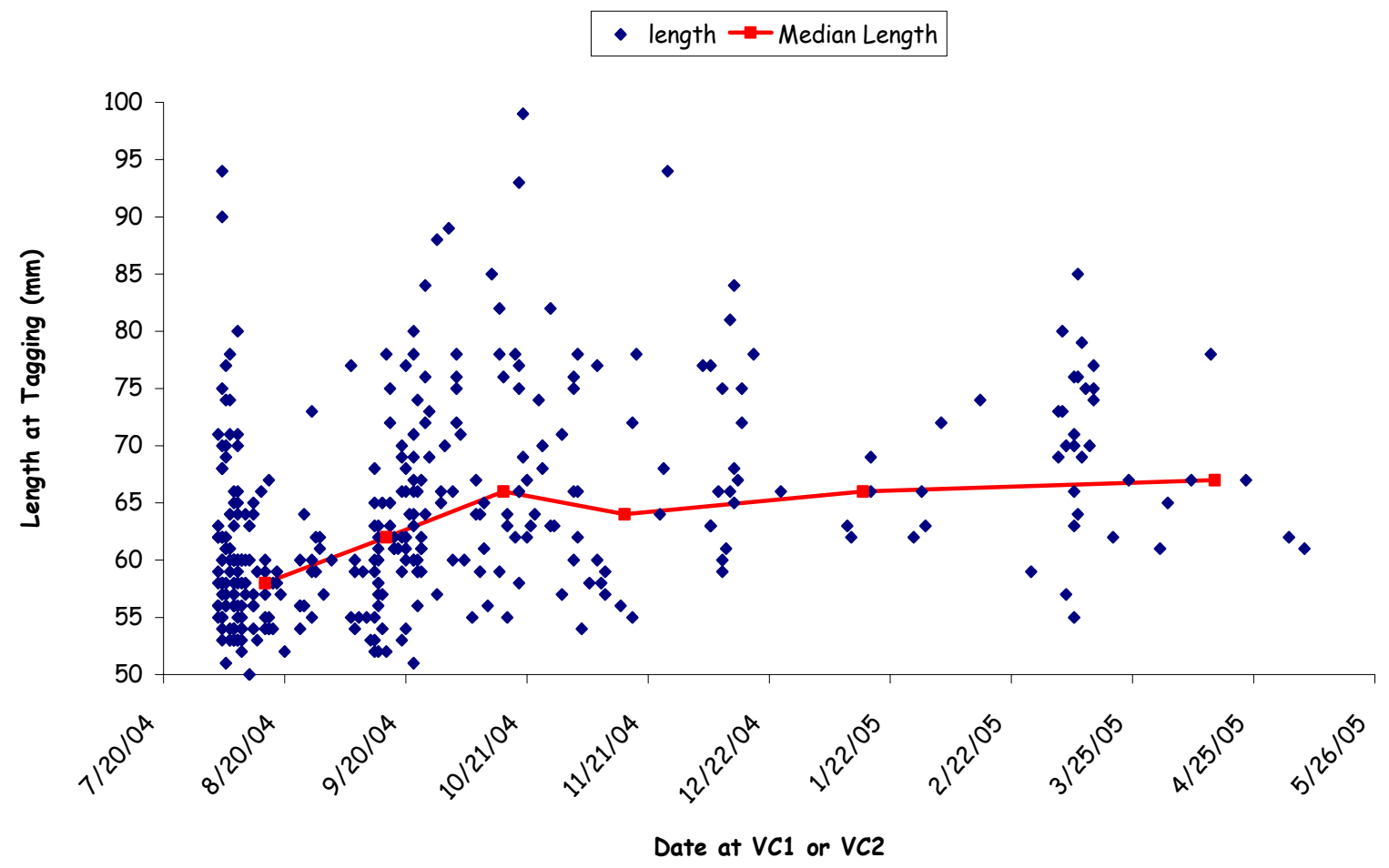

Figure 3. Fork length and median fork length of the 357 summer-tagged parr detected at instream PIT-tag monitoring antennas in lower Valley Creek (upper and lower monitors combined) from August 2004 through June 2005. 


\section{Recaptures at Traps and Dams}

A total of 450 wild fish PIT-tagged in summer 2004 were recaptured at traps above Lower Granite Dam from summer/fall 2004 to spring 2005. At Little Goose Dam, a total of 656 study fish were diverted by the separation-by-code system in the juvenile fish facility, and at McNary Dam a total of 6 study fish were recaptured (Table 4). As shown in Table 4, fish from both the traps and Little Goose Dam had variable increases in weight and length, depending upon the elapsed time between release and recapture.

\section{Detections at Dams}

Based on expanded detections (1,568 fish) at Lower Granite Dam from 4 April to 20 June 2005, estimated parr-to-smolt survival for Idaho fish averaged 7.9\% ( $\mathrm{SE}=0.3 \%)$ and ranged from 3.7 to $11.3 \%$ ( $\mathrm{SE}=1.0-2.0 \%$; Table 5; Appendix Tables 5-20). ${ }^{\dagger}$ An additional 329 first-time detections (unadjusted) were recorded at Little Goose, Lower Monumental, McNary, and John Day Dams (Appendix Tables 5-19 and 21-23). No first-time PIT-tag detections occurred at Bonneville Dam, Ice Harbor Dam, or in the surface trawl detector operated near the mouth of the Columbia River. By comparing all first-time detections at interrogation dams $(1,441)$ to the expanded number of detections at Lower Granite Dam $(1,568)$, we estimated that $8.1 \%$ of the wild fish from Idaho passed the dams undetected.

For parr tagged in Idaho, average fork length at release was $63.2 \mathrm{~mm}$ (Table 1; Appendix Table 2). However, fish from this group that were detected the following spring at dams had significantly higher average fork length at release $(65.8 \mathrm{~mm} ; P<0.01)$. Fish that were larger at release tended to pass Lower Granite Dam earlier than their smaller cohorts (Figure 4). The release-length distribution of detected fish was also significantly different from that of released fish in all length categories $(P<0.01$; Figure 5).

† Due to rounding of numbers, the expanded detection numbers at Lower Granite Dam in Table 5 may vary slightly from expanded detection numbers in Appendix Tables 5-20. 
Table 4. Recapture information on PIT-tagged wild spring/summer Chinook salmon from Idaho that were tagged in summer 2004 and recaptured by the separation-by-code system in juvenile fish bypass system at Little Goose Dam in 2005 and at traps and dams downstream from Little Goose in summer and fall 2004 and spring 2005.

\begin{tabular}{|c|c|c|c|c|c|c|c|c|c|c|}
\hline & \multicolumn{3}{|c|}{ Length gain $(\mathrm{mm})$} & \multicolumn{3}{|c|}{ Weight gain (g) } & \multicolumn{2}{|c|}{$\begin{array}{c}\text { Condition } \\
\text { Factor }\end{array}$} & \multicolumn{2}{|c|}{$\begin{array}{l}\text { Recapture } \\
\text { interval (d) }\end{array}$} \\
\hline & $\mathrm{n}$ & Range & Mean & n* & Range & Mean & Release & Recapture & Range & Mean \\
\hline \multicolumn{11}{|l|}{ Little Goose Dam } \\
\hline Bear Valley Creek & 26 & $33-65$ & 50.0 & 15 & $7.7-14.1$ & 10.5 & 1.20 & 0.96 & $281-332$ & 302 \\
\hline Elk Creek & 49 & $20-61$ & 46.0 & 40 & $3.1-16.4$ & 9.8 & 1.26 & 0.98 & $278-329$ & 302 \\
\hline Sulphur Creek & 30 & $27-71$ & 45.8 & 11 & $4.5-14.5$ & 8.5 & 1.19 & 0.96 & $277-316$ & 293 \\
\hline Marsh Creek & 37 & $17-56$ & 39.3 & 21 & $3.6-12.7$ & 8.2 & 1.28 & 0.95 & 274-309 & 290 \\
\hline Cape Horn Creek & 26 & $24-64$ & 43.5 & 14 & $4.9-14.5$ & 9.3 & 1.26 & 1.02 & $273-313$ & 290 \\
\hline Valley Creek & 56 & $31-64$ & 49.4 & 33 & $6.8-16.1$ & 11.3 & 1.19 & 0.97 & $269-323$ & 294 \\
\hline Loon Creek & 60 & $30-68$ & 49.3 & 46 & $5.1-15.1$ & 10.7 & 1.36 & 0.98 & $265-307$ & 287 \\
\hline Camas Creek & 80 & $21-61$ & 43.8 & 19 & $4.8-13.5$ & 8.8 & 1.48 & 0.97 & $261-312$ & 287 \\
\hline Herd Creek & 61 & $22-68$ & 45.3 & 13 & $4.2-14.9$ & 8.8 & 1.18 & 0.93 & $263-300$ & 278 \\
\hline Big Creek (upper) & 47 & $19-63$ & 42.5 & 24 & $6-16.3$ & 9.8 & 1.16 & 0.98 & $261-313$ & 281 \\
\hline South Fork Salmon River & 47 & $18-63$ & 43.8 & 25 & $5-15.7$ & 9.9 & 1.15 & 0.99 & $248-293$ & 273 \\
\hline Big Creek (lower) & 17 & $28-49$ & 37.9 & 4 & $5.6-11.5$ & 8.3 & 1.08 & 0.92 & $255-265$ & 261 \\
\hline West Fork Chamberlain $\mathrm{Cr}$ & 53 & $25-54$ & 40.2 & 23 & $5.4-13.5$ & 8.7 & 1.21 & 0.91 & $254-292$ & 263 \\
\hline Secesh River & 42 & $23-68$ & 43.2 & 26 & $4.3-12.5$ & 8.5 & 1.13 & 0.93 & $242-291$ & 257 \\
\hline Lake Creek & 23 & $27-51$ & 42.4 & 4 & $4.6-10.5$ & 7.7 & 1.08 & 0.92 & $245-286$ & 253 \\
\hline Totals or averages & 654 & $17-71$ & 44.5 & 318 & $3.1-16.4$ & 9.6 & 1.24 & 0.96 & $242-332$ & 282 \\
\hline
\end{tabular}


Table 4. Continued.

\begin{tabular}{|c|c|c|c|c|c|c|c|c|c|c|}
\hline & \multicolumn{3}{|c|}{ Length gain $(\mathrm{mm})$} & \multicolumn{3}{|c|}{ Weight gain $(\mathrm{g})$} & \multicolumn{2}{|c|}{$\begin{array}{l}\text { Condition } \\
\text { Factor }\end{array}$} & \multicolumn{2}{|c|}{$\begin{array}{l}\text { Recapture } \\
\text { interval (d) }\end{array}$} \\
\hline & $\mathrm{n}$ & Range & Mean & $\mathrm{n}^{*}$ & Range & Mean & Release & Recapture & Range & Mean \\
\hline \multicolumn{11}{|l|}{ Traps } \\
\hline \multicolumn{11}{|l|}{ South Fork Salmon River } \\
\hline Knox Bridge (fall) & 151 & $-4-10$ & 0.3 & 62 & $-0.8-1.1$ & -0.08 & 1.12 & 1.13 & $1-65$ & 20 \\
\hline Knox Bridge (spring) & 22 & $5-22$ & 12.6 & 11 & $0.3-2.8$ & 1.47 & 1.20 & 1.10 & $192-254$ & 234 \\
\hline Lower SF Salmon R. (fall) & -- & -- & -- & -- & -- & -- & -- & -- & -- & -- \\
\hline \multicolumn{11}{|l|}{ Lake Creek } \\
\hline Fall & 75 & $-4-7$ & 1.0 & 16 & $-0.5-0.8$ & 0.01 & 1.16 & 1.08 & $1-62$ & 17 \\
\hline Spring & 3 & $3-9$ & 6.7 & 0 & -- & -- & -- & 1.03 & $224-241$ & 235 \\
\hline \multicolumn{11}{|l|}{ Secesh River } \\
\hline Fall & 29 & $-1-10$ & 2.2 & 6 & $-0.2-0.89$ & 0.17 & 0.19 & 1.06 & $1-69$ & 25 \\
\hline Spring & 4 & $8-27$ & 16.8 & 0 & -- & -- & 1.09 & -- & $231-284$ & 250 \\
\hline \multicolumn{11}{|l|}{ Marsh Creek } \\
\hline Fall & 158 & $-32-22$ & 1.8 & 0 & -- & -- & 1.25 & -- & $1-83$ & 11 \\
\hline Spring & 2 & $25-28$ & 27.0 & 0 & -- & -- & 1.48 & -- & $239-251$ & 245 \\
\hline Salmon River (spring) & 0 & -- & -- & 0 & -- & -- & -- & -- & -- & -- \\
\hline Snake River (spring) & 2 & $39-41$ & 40.0 & 0 & -- & -- & 1.67 & -- & $283-285$ & 284 \\
\hline Trap Totals & 446 & & & 95 & & & & & & \\
\hline \multicolumn{11}{|l|}{ McNary Dam } \\
\hline & 6 & -- & -- & 0 & -- & -- & 1.28 & -- & $222-306$ & 270 \\
\hline
\end{tabular}

* Fewer fish weights were available for comparison because fewer fish had been weighed when they were tagged as parr. 
Table 5. Summary of observed and expanded detections at Lower Granite Dam in 2005 of PIT-tagged wild spring/summer Chinook salmon smolts marked in Idaho the previous year as parr. Table includes expanded numbers used for parr-to-smolt survival estimates and also includes standard error percentages (SE\%). See Table 1 for numbers released.

\begin{tabular}{|c|c|c|c|c|}
\hline & \multicolumn{4}{|c|}{ Lower Granite Dam detections } \\
\hline & \multicolumn{2}{|c|}{ Observed } & \multicolumn{2}{|c|}{ Expanded } \\
\hline & $\mathrm{N}$ & $\%$ & $\mathrm{~N}$ & $\%(\mathrm{SE})$ \\
\hline Bear Valley Creek & 39 & 2.6 & 55 & $3.7(1.0)$ \\
\hline Elk Creek & 57 & 3.9 & 86 & $5.9(1.0)$ \\
\hline Marsh Creek & 82 & 5.5 & 110 & $7.3(1.0)$ \\
\hline Cape Horn Creek & 54 & 5.3 & 78 & $7.6(1.0)$ \\
\hline Sulphur Creek & 57 & 4.9 & 79 & $6.9(1.0)$ \\
\hline Valley Creek & 95 & 3.8 & 147 & $5.9(1.0)$ \\
\hline Loon Creek & 102 & 6.8 & 148 & $9.9(1.0)$ \\
\hline Camas Creek & 122 & 8.1 & 176 & $11.7(1.0)$ \\
\hline Herd Creek & 125 & 8.0 & 174 & $11.1(1.0)$ \\
\hline Big Creek (upper) & 91 & 6.0 & 132 & $8.7(1.0)$ \\
\hline Big Creek (lower) & 34 & 9.1 & 42 & $11.3(2.0)$ \\
\hline W Fork Chamberlain Creek* & 105 & 7.9 & 134 & $10.1(1.0)$ \\
\hline S Fork Salmon River & 58 & 4.7 & 87 & $7.1(1.0)$ \\
\hline Secesh River & 58 & 5.4 & 76 & $7.1(1.0)$ \\
\hline Lake Creek & 33 & 5.1 & 44 & $6.8(1.0)$ \\
\hline Totals or averages & 1,112 & 5.6 & 1,568 & $7.9(0.3)$ \\
\hline
\end{tabular}

* Includes fish from Chamberlain Creek. 


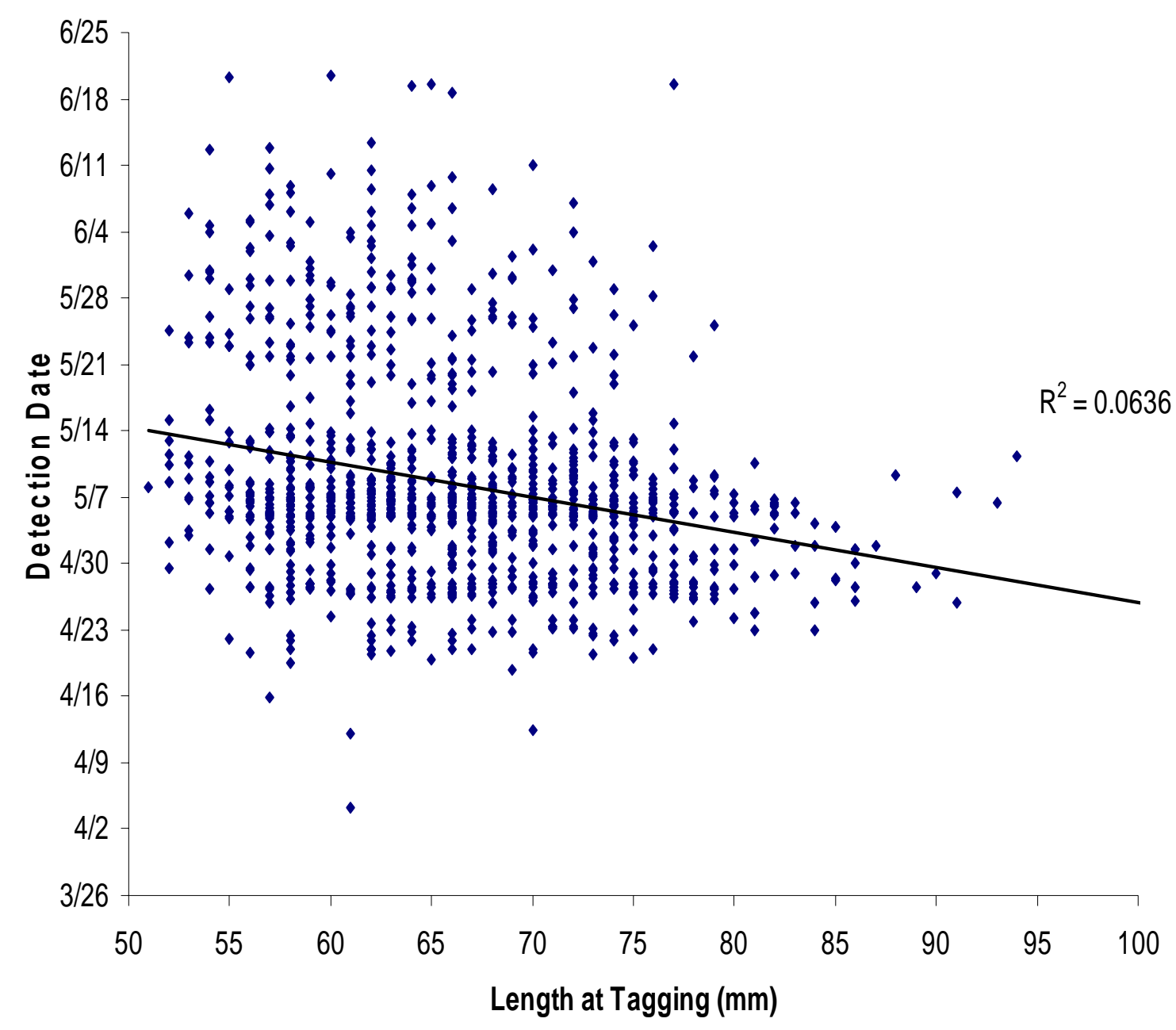

Figure 4. The relationship between fork length of parr at tagging (in 2004) to detection date at Lower Granite Dam in 2005. 


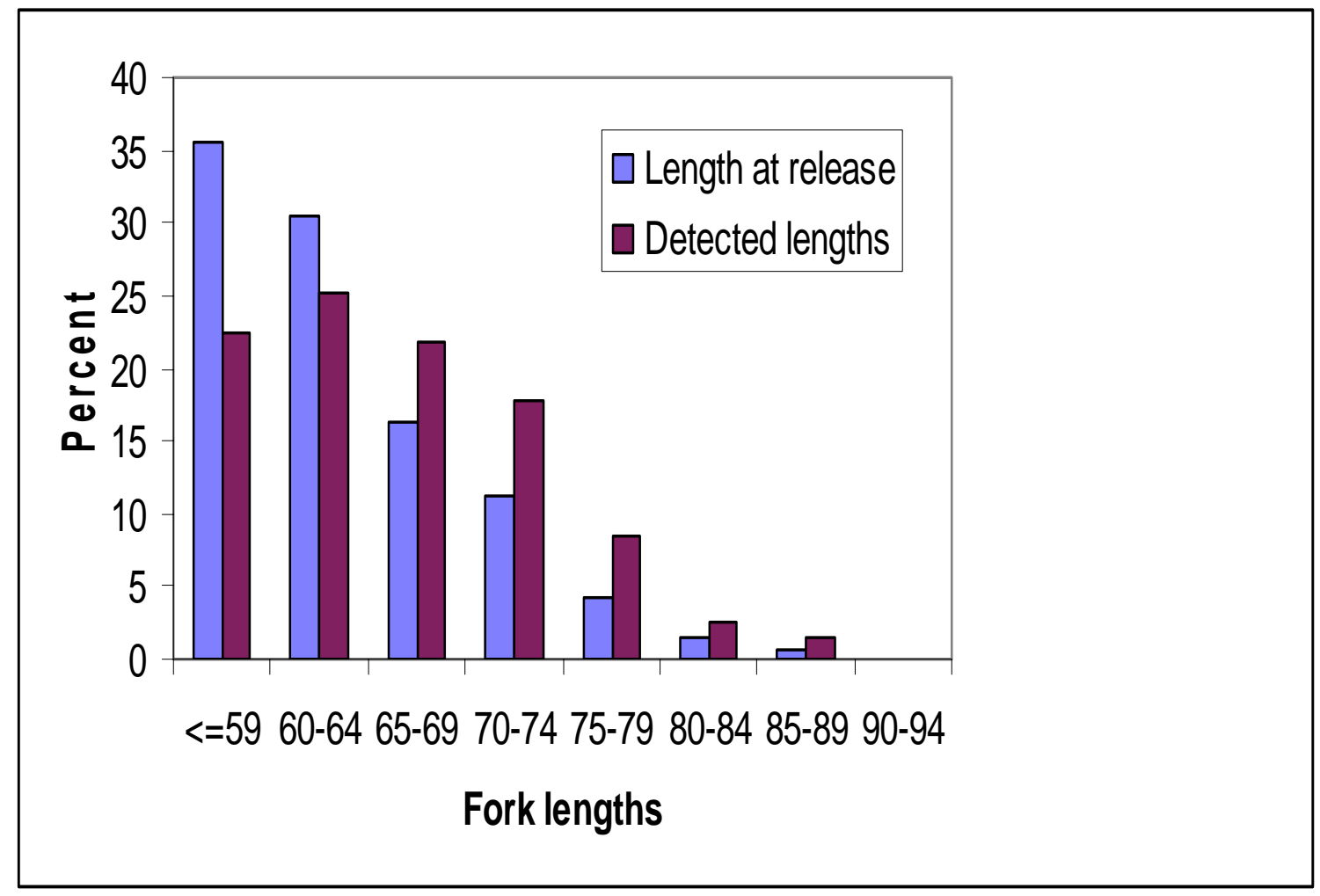

Figure 5. Percent by fork length in 5-mm increments of PIT-tagged wild spring/summer Chinook salmon parr released in Idaho streams in $2004(\mathrm{n}=19,845)$ and percent of fish in these same length increments detected at dams in spring and summer $2005(\mathrm{n}=1,439)$. 
In 2005, we again found a significant difference in fork length at release between fish that passed through Lower Granite Dam in April-May and those that passed the dam after May $(P<0.01)$. Fish arriving at the dam in April-May were an average of $4.5 \mathrm{~mm}$ larger at release than fish arriving after May. These data suggest that fish size influences migration timing or overwinter location.

In 2005, we estimated a $13.9 \%$ overall survival rate to Lower Granite Dam for Chinook salmon juveniles previously detected at the Valley Creek instream PIT-tag monitors. Overall parr-to-smolt survival estimated for fish from this stream was 5.9\% (Table 5). Estimated parr-to-smolt survival rates in 2004-2005 were 10.9\% for fish leaving Valley Creek in late-summer/fall, $22.7 \%$ for those leaving in winter, and $32.9 \%$ for fish leaving in spring.

\section{Migration Timing}

\section{Lower Granite Dam}

Passage timing at Lower Granite Dam varied for fish from the 19 Idaho and Oregon streams (Figure 6). Among all 19 Idaho and Oregon streams (Appendix Tables 1a-1b, Figure 6), fish from the Lostine River had a significantly earlier timing for 10th percentile passage than fish from all other streams except Imnaha, Minam, and Secesh Rivers, and Bear Valley, Catherine, Lake, and Big (lower) Creeks $(P<0.05)$.

The 10th percentile passage date of fish from Loon and Sulphur Creeks was significantly later than that of fish from all other streams except Cape Horn, Camas, Valley, Big (upper), Marsh, Herd, Elk, and Chamberlain/WF Chamberlain Creeks, and the South Fork Salmon River $(P<0.05)$. Standard errors on these passage estimates ranged from 0.6 to $3.9 \mathrm{~d}$ (median $1.7 \mathrm{~d}$ ). Overall, the 10th percentile passage dates for fish from all 19 streams ranged from 16 April to 4 May (Appendix Table 1a-1b).

The 50th percentile passage dates at Lower Granite Dam were significantly earlier for fish from Lake Creek than for fish from all other streams except Lostine, Imnaha, and Secesh Rivers, and Chamberlain/WF Chamberlain and Big (lower) Creeks $(P<0.05)$. Fish from Valley Creek arrived significantly later at the dam than fish from all other streams except Loon, Elk, and Catherine Creeks and the South Fork Salmon River $(P<0.05)$. Standard errors on these passage estimates ranged from 0.5 to $4.2 \mathrm{~d}$ (median $1.5 \mathrm{~d})$. The overall 50th percentile passage dates for fish from all 19 streams ranged from 28 April to 15 May (Appendix Tables 1a-1b). 


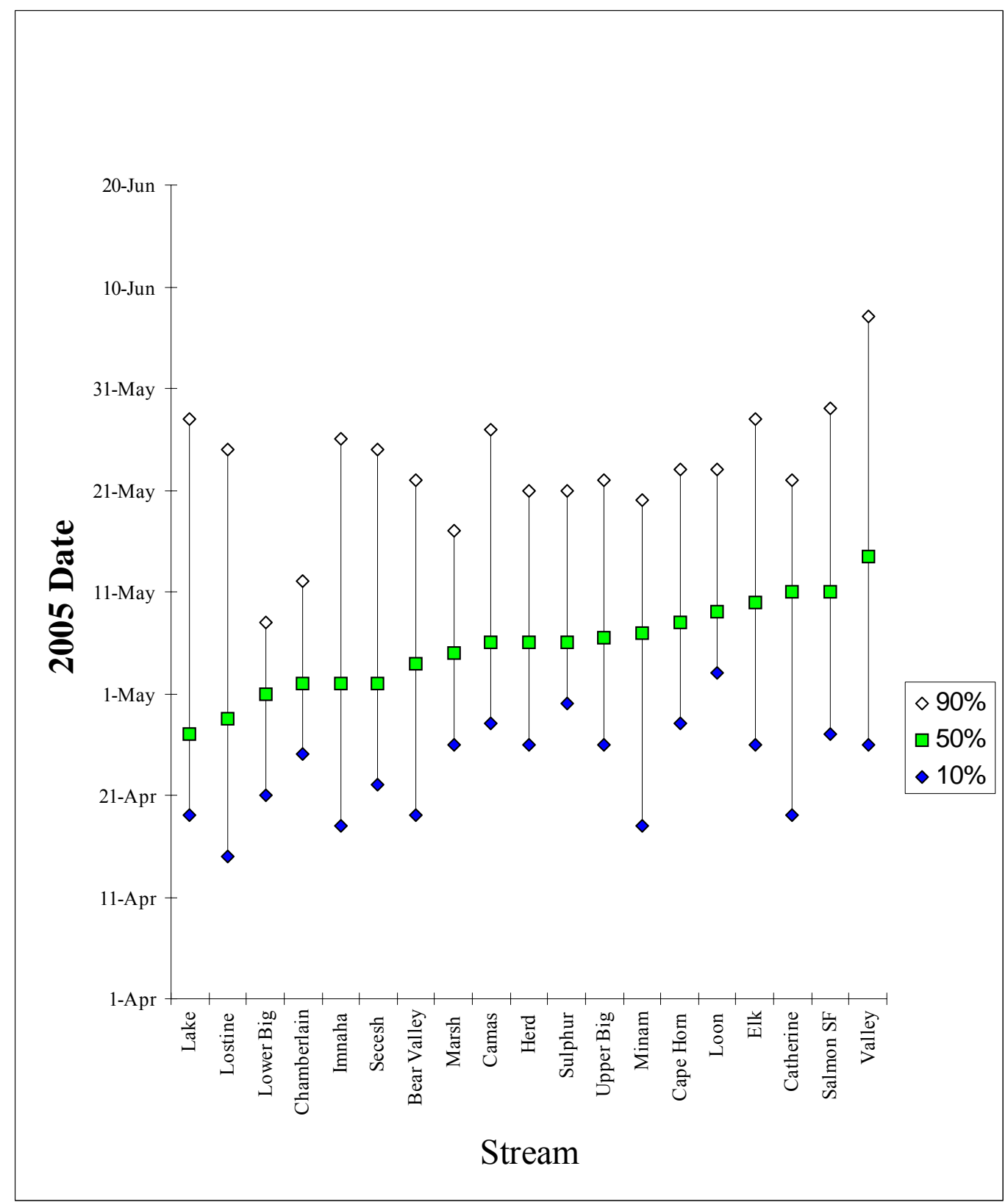

Figure 6. Estimated passage distributions at Lower Granite Dam in 2005 for wild spring/summer Chinook salmon smolts marked as parr in Idaho and Oregon in 2004. Chamberlain and West Fork Chamberlain Creeks are combined and Big Creek is divided into lower and upper portions for these analyses. See Appendix Tables 5-19 for daily estimated passage numbers from Idaho streams at the dam. 
In terms of the 90th percentile passage date at the dam, fish from Big (lower) Creek were significantly earlier than fish from all other streams except Chamberlain/WF Chamberlain Creek $(P<0.05)$. Fish from Valley Creek were significantly later than fish from all other streams except Lake Creek and the South Fork Salmon River $(P<0.05)$. Standard errors on these passage estimates ranged from 0.5 to $5.9 \mathrm{~d}$ (median $2.5 \mathrm{~d}$ ). The overall 90th percentile passage dates for fish from all streams ranged from 9 May to 8 June (Appendix Tables 1a-1b).

Migration timing at Lower Granite Dam based on streams with 8 or more years of data indicated that 10th, 50th, and 90th percentage of passage timing varied between streams (Table 6). Secesh River fish had a significantly earlier timing at Lower Granite Dam for the 10th percentile passage than fish from all other streams except Lake and $\operatorname{Big}($ lower)/Rush Creeks and Lostine and Imnaha (upper) Rivers $(P<0.05)$. Also, Big Creek (upper) fish had significantly later migration timing at the dam than all the other streams except Loon and Catherine Creeks $(P<0.05)$.

For the 50th percentile passage at the dam, Secesh River and Big(lower)/Rush Creeks had significantly earlier arrival timing than fish from all other streams except Lake and Herd Creeks $(P<0.05)$. Fish from Big Creek (upper) had significantly later timing at the dam than fish from all other streams $(P<0.05)$. For the 90 th percentile passage at the dam, Big(lower)/Rush Creeks fish had significantly earlier timing than fish from all other streams except Herd Creek $(P<0.05)$. Fish from Big Creek (upper) and South Fork of the Salmon River had significantly later timing at the dam than fish from all other streams except Cape Horn, Lake, Catherine, Valley, and Chamberlain/WF Chamberlain Creeks $(P<0.05)$. 
Table 6. The $95 \%$ confidence interval (CI) and mean passage dates of 10th, 50th, and 90th percentiles with standard errors (SE) in days, at Lower Granite Dam for wild spring/summer Chinook salmon smolts from streams in Idaho and Oregon over all data years.

\begin{tabular}{|c|c|c|c|c|c|}
\hline \multirow[b]{2}{*}{ Stream } & \multicolumn{4}{|c|}{ Percentile passage dates at Lower Granite Dam } & \multirow[b]{2}{*}{ Data years } \\
\hline & $95 \% \mathrm{CI}$ & 10th (SE) & 50th (SE) & 90th (SE) & \\
\hline & Lo CI & 11 April & 23 April & 23 May & \\
\hline & Up CI & 17 April & 30 April & 08 June & \\
\hline \multirow[t]{3}{*}{ Secesh River } & Mean & 14 April (1) & 27 April (1) & 31 May (4) & 17 \\
\hline & Lo CI & 15 April & 07 May & 01 June & \\
\hline & Up CI & 23 April & 13 May & 11 June & \\
\hline \multirow[t]{3}{*}{ South Fork Salmon River } & Mean & 19 April (2) & 10 May (2) & 06 June (2) & 16 \\
\hline & Lo CI & 23 April & 11 May & 28 May & \\
\hline & Up CI & 30 April & 17 May & 08 June & \\
\hline \multirow[t]{3}{*}{ Catherine Creek } & Mean & 26 April (2) & 14 May (2) & 02 June (3) & 15 \\
\hline & Lo CI & 14 April & 28 April & 18 May & \\
\hline & Up CI & 20 April & 06 May & 28 May & \\
\hline \multirow[t]{3}{*}{ Imnaha River (upper) } & Mean & 17 April (1) & 02 May (2) & 23 May (2) & 13 \\
\hline & Lo CI & 18 April & 04 May & 27 May & \\
\hline & Up CI & 26 April & 12 May & 06 June & \\
\hline \multirow[t]{3}{*}{ Bear Valley Creek } & Mean & 22 April (2) & 08 May (2) & 01 June (2) & 14 \\
\hline & Lo CI & 25 April & 13 May & 30 May & \\
\hline & Up CI & 06 May & 27 May & 21 June & \\
\hline \multirow[t]{3}{*}{ Big Creek (upper) } & Mean & 01 May (2) & 20 May (3) & 10 June (5) & 11 \\
\hline & Lo CI & 16 April & 02 May & 25 May & \\
\hline & Up CI & 25 April & 10 May & 05 June & \\
\hline \multirow[t]{3}{*}{ Elk Creek } & Mean & 20 April (2) & 06 May (2) & 30 May (3) & 13 \\
\hline & Lo CI & 20 April & 09 May & 30 May & \\
\hline & Up CI & 30 April & 18 May & 12 June & \\
\hline \multirow[t]{3}{*}{ Valley Creek } & Mean & 25 April (2) & 14 May (2) & 06 June (3) & 14 \\
\hline & Lo CI & 17 April & 01 May & 20 May & \\
\hline & Up CI & 23 April & 09 May & 30 May & \\
\hline \multirow[t]{3}{*}{ Marsh Creek } & Mean & 20 April (1) & 05 May (2) & 25 May (2) & 12 \\
\hline & Lo CI & 12 April & 26 April & 27 May & \\
\hline & Up CI & 19 April & 04 May & 11 June & \\
\hline \multirow[t]{3}{*}{ Lake Creek } & Mean & 15 April (2) & 30 April (2) & 03 June (4) & 13 \\
\hline & Lo CI & 12 April & 30 April & 17 May & \\
\hline & Up CI & 21 April & 08 May & 27 May & \\
\hline \multirow[t]{3}{*}{ Lostine River } & Mean & 16 April (2) & 04 May (2) & 22 May (2) & 14 \\
\hline & Lo CI & 14 April & 01 May & 20 May & \\
\hline & Up CI & 28 April & 20 May & 07 June & \\
\hline \multirow[t]{3}{*}{ Sulphur Creek } & Mean & 21 April (3) & 11 May (4) & 29 May (4) & 9 \\
\hline & Lo CI & 19 April & 06 May & 24 May & \\
\hline & Up CI & 01 May & 20 May & 11 June & \\
\hline Cape Horn Creek & Mean & 25 April (3) & 13 May (3) & 02 June (4) & 9 \\
\hline
\end{tabular}


Table 6. Continued.

\begin{tabular}{|c|c|c|c|c|c|}
\hline \multirow[b]{2}{*}{$\underline{\text { Stream }}$} & \multicolumn{4}{|c|}{ Percentile passage dates at Lower Granite Dam } & \multirow[b]{2}{*}{ Data year } \\
\hline & $95 \% \mathrm{CI}$ & 10th (SE) & 50th (SE) & 90th (SE) & \\
\hline \multirow{5}{*}{ Big (lower)/Rush Creeks } & Lo CI & 16 April & 26 April & 07 May & \\
\hline & Up CI & 21 April & 30 April & 16 May & \\
\hline & Mean & 19 April (1) & 28 April (1) & 12 May (2) & 9 \\
\hline & Lo CI & 15 April & 25 April & 13 May & \\
\hline & Up CI & 24 April & 07 May & 23 May & \\
\hline E. F. Salmon River & Mean & 19 April (2) & 01 May (2) & 18 May (2) & 7 \\
\hline & $\begin{array}{l}\text { Lo CI } \\
\text { Up CI } \\
\text { Mean }\end{array}$ & $\begin{array}{c}24 \text { April } \\
\text { 02 May } \\
28 \text { April (2) }\end{array}$ & $\begin{array}{c}07 \text { May } \\
14 \text { May } \\
11 \text { May (2) }\end{array}$ & $\begin{array}{c}19 \text { May } \\
27 \text { May } \\
23 \text { May (2) }\end{array}$ & 8 \\
\hline Loon Creek & $\begin{array}{l}\text { Lo CI } \\
\text { Up CI }\end{array}$ & $\begin{array}{l}16 \text { April } \\
24 \text { April }\end{array}$ & $\begin{array}{l}26 \text { April } \\
03 \text { May }\end{array}$ & $\begin{array}{l}11 \text { May } \\
19 \text { May }\end{array}$ & \\
\hline \multirow[t]{2}{*}{ Herd Creek } & Mean & 20 April (2) & 30 April (2) & 15 May (2) & 9 \\
\hline & $\begin{array}{l}\text { Lo CI } \\
\text { Up CI } \\
\text { Mean }\end{array}$ & $\begin{array}{c}23 \text { April } \\
10 \text { May } \\
01 \text { May (3) }\end{array}$ & $\begin{array}{c}13 \text { May } \\
\text { 04 June } \\
\text { 24 May (4) }\end{array}$ & $\begin{array}{c}21 \text { May } \\
\text { 03 July } \\
\text { 12 June (8) }\end{array}$ & 5 \\
\hline Grand Ronde River (upper) & $\begin{array}{l}\text { Lo CI } \\
\text { Up CI }\end{array}$ & $\begin{array}{l}05 \text { April } \\
20 \text { April }\end{array}$ & 14 April & 02 May & \\
\hline Imnaha River (lower) & Mean & 12 April (2) & 25 April (3) & 09 May (2) & 4 \\
\hline Chamberlain/ & $\begin{array}{l}\text { Lo CI } \\
\text { Up CI }\end{array}$ & $\begin{array}{l}16 \text { April } \\
26 \text { April }\end{array}$ & $\begin{array}{l}27 \text { April } \\
12 \text { May }\end{array}$ & $\begin{array}{l}16 \text { May } \\
20 \text { June }\end{array}$ & \\
\hline \multirow[t]{2}{*}{ W.F. Chamberlain Creeks } & Mean & 21 April (2) & 04 May (3) & 03 June (7) & 8 \\
\hline & $\begin{array}{l}\text { Lo CI } \\
\text { Up CI } \\
\text { Mean }\end{array}$ & $\begin{array}{c}22 \text { April } \\
\text { 02 May } \\
27 \text { April (2) }\end{array}$ & $\begin{array}{c}08 \text { May } \\
21 \text { May } \\
14 \text { May (3) }\end{array}$ & $\begin{array}{c}25 \text { May } \\
01 \text { June } \\
29 \text { May (2) }\end{array}$ & 7 \\
\hline Camas Creek & $\begin{array}{l}\text { Lo CI } \\
\text { Up CI }\end{array}$ & $\begin{array}{l}12 \text { April } \\
26 \text { April }\end{array}$ & $\begin{array}{l}25 \text { April } \\
15 \text { May }\end{array}$ & $\begin{array}{l}18 \text { May } \\
31 \text { May }\end{array}$ & \\
\hline Minam River & Mean & 19 April (2) & 05 May (3) & 25 May (2) & 5 \\
\hline
\end{tabular}




\section{Comparison with Flows}

We grouped first-time detections (expanded) at Lower Granite Dam of all Idaho and Oregon streams combined and compared their collective timing with river flows during the same periods (Figure 7 and Appendix Table 20). Overall, passage at the dam during 2005 occurred between early April and late-June, with the middle 80th percentile passage occurring from 25 April to 24 May (Table 7). The peak passage date was 5 May, which coincided with a low flow of $60.4 \mathrm{kcfs}$ (Appendix Table 20).

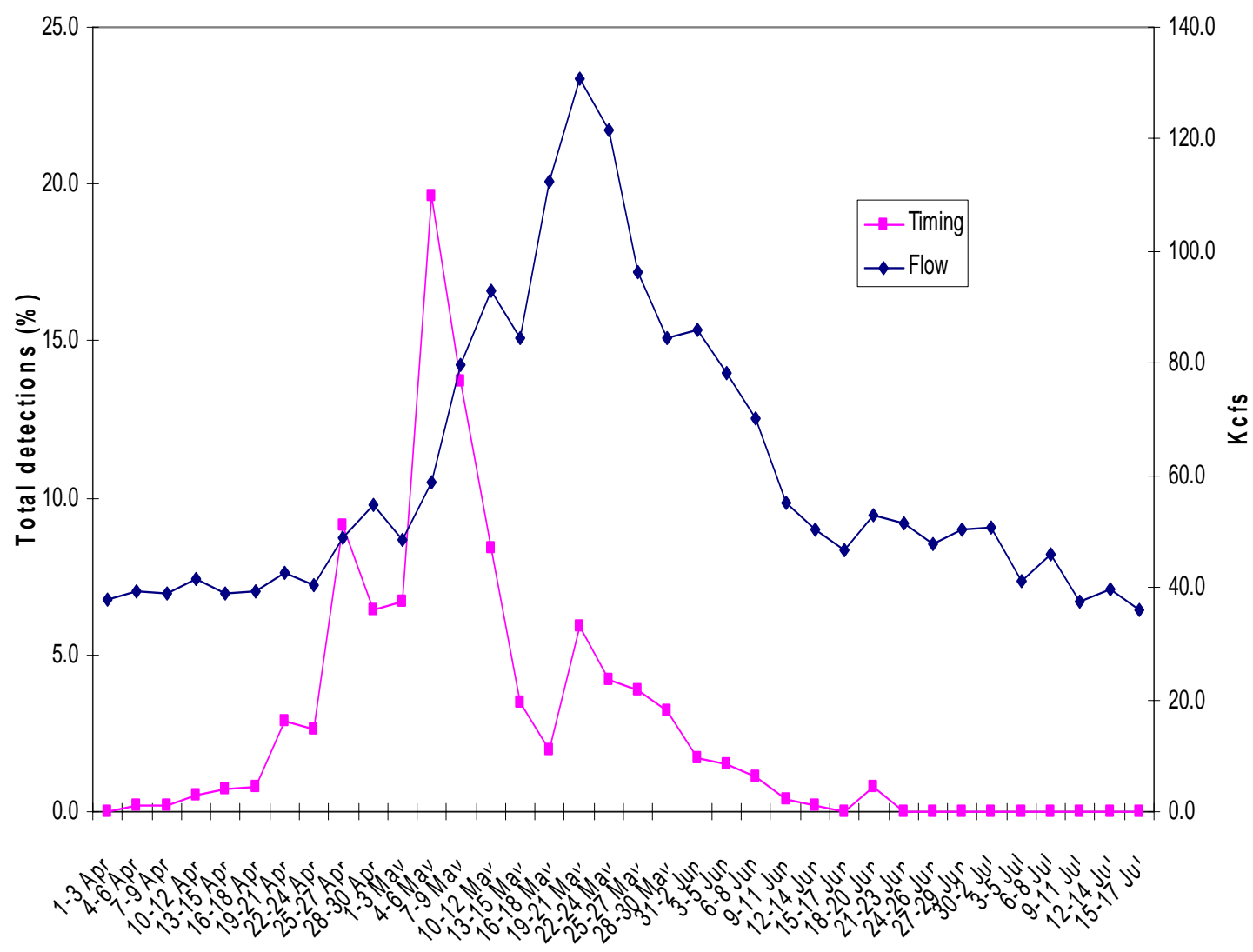

Figure 7. Overall migration timing of PIT-tagged wild spring/summer Chinook salmon smolts with associated river flows at Lower Granite Dam, 2005. Daily detections from 15 Idaho and 4 Oregon streams were pooled in 3-d intervals and expanded based on daily detection probability. River flows at the dam were averaged daily over the same periods. 
Table 7. Accumulated and 2005 passage dates at Lower Granite Dam for combined populations of wild spring/summer Chinook salmon smolts PIT tagged as summer parr in Idaho and Oregon streams.

\begin{tabular}{|c|c|c|c|c|}
\hline \multirow[b]{2}{*}{ Year } & \multicolumn{4}{|c|}{ Percentile passage dates at Lower Granite Dam } \\
\hline & 10th & 50 th & 90th & Range \\
\hline $1989^{\mathrm{a}}$ & 23 April & 14 May & 13 June & 04 April-22 July \\
\hline 1990 & 19 April & 07 May & 07 June & 05 April-18 July \\
\hline 1991 & 01 May & 18 May & 12 June & 13 April-20 July \\
\hline 1992 & 15 April & 02 May & 27 May & 05 April-27 July \\
\hline 1993 & 26 April & 14 May & 31 May & 14 April-10 August \\
\hline 1994 & 22 April & 08 May & 01 June & 13 April-04 Sept. \\
\hline 1995 & 17 April & 09 May & 04 June & 08 April-22 Sept. \\
\hline $1996^{\mathrm{a}, \mathrm{b}}$ & 15 April & 27 April & 19 May & 09 April-15 July \\
\hline $1997^{\mathrm{a}, \mathrm{b}}$ & 12 April & 24 April & 18 May & 31 March-22 Sept. \\
\hline $1998^{\mathrm{b}}$ & 11 April & 02 May & 23 May & 31 March-07 Aug. \\
\hline 1999 & 20 April & 03 May & 28 May & 27 March-08 July \\
\hline 2000 & 17 April & 07 May & 30 May & 10 April-20 July \\
\hline 2001 & 26 April & 09 May & 27 May & 06 April-07 July \\
\hline 2002 & 16 April & 03 May & 30 May & 28 March-05 July \\
\hline 2003 & 18 April & 11 May & 29 May & 31 March-04 July \\
\hline 2004 & 16 April & 03 May & 26 May & 01 April-16 July \\
\hline 2005 & 25 April & 07 May & 24 May & 04 April-20 June \\
\hline
\end{tabular}

a No fish were tagged from the Middle Fork of the Salmon River drainage for this migration year.

$\mathrm{b}$ This migration year represented by a much higher proportion of fish from Oregon streams than other years. 


\section{Environmental Information}

Environmental factors varied by month and between locations (Appendix Tables 24-28), as did the percentage of fish collected and/or detected at adjacent traps (Appendix Figures 1-7). Weather/climate and stream-flow data also varied by month and between locations (Appendix Table 29). 


\section{DISCUSSION}

Mortality rates associated with collection and tagging in 2004 were comparable to those in earlier years (Achord et al. 1992, 1994, 1995a,b, 1996a,b, 1997, 1998, 2000, 2001a,b, 2002, 2003, 2004, 2005).

The instream PIT-tag monitoring system used in Valley Creek in 2003-2004 and 2004-2005, enabled us to calculate survival estimates and migration timing for wild Chinook salmon juveniles leaving this stream. However, only $10-14 \%$ of the tagged juvenile Chinook salmon were detected at instream monitors during these two years. In order to increase precision for these estimates, we will need to increase either the number of antennas or the tagging sample size. Significantly, the results from instream monitoring indicated that a higher-than-expected proportion of wild juvenile Chinook salmon were observed moving out of Valley Creek in winter. This has important implications for intensive fish monitoring studies throughout Idaho that use rotary screw traps, since these traps are inoperable during winter in most areas. Perhaps a combination of rotary screw traps and instream PIT-tag monitors may be appropriate for some locations or studies.

Overall mean growth per day from the parr to smolt stage, as measured at Little Goose Dam in 2005, was identical to that observed in $2001(0.16 \mathrm{~mm} / \mathrm{d})$ (Achord et al. 2002). However, overall mean weight gain was higher in $2001(0.042 \mathrm{~g} / \mathrm{d})$ than in 2005 $(0.034 \mathrm{~g} / \mathrm{d})$. Length and weight growth rates observed in 2005 were higher than in the previous 3 years (Achord et al. 2003, 2004, 2005).

Annual combined (Idaho and Oregon steams) parr-to-smolt survival estimates over the last 13 years have ranged from 8.1 to $24.4 \%$, with an average annual survival rate of $16.2 \%$. We observed the lowest parr-to-smolt survival in 2004 (8.1\%) and 2005 $(8.4 \%)$. These low estimates may have resulted from conditions with much higher parr density. Returns of wild adults to the Snake River basin from 2001 to 2003 were more than one order of magnitude greater than returns from 1994 to 1996, when we measured the highest parr to smolt survival (20.6 to $24.4 \%$ ).

In 2005, as observed in previous years, larger fish (at tagging) tended to migrate earlier than smaller fish at Lower Granite Dam. In addition, we again observed that wild fish detected at the dam in April and May had been significantly larger at release than fish migrating after May. This suggests that size is an important factor related either to 
the initiation of smoltification or to other life-history dynamics that affect the migration timing of wild fish. We also observed that the dates of the overall 50 and 90th percentile passage of wild fish at the dam occurred in early and late May, respectively.

In spring 2005, climatic conditions were cool and wet, but flows were considered low until mid-May. As noted in our previous annual reports, wild Chinook salmon smolt passage timing at Lower Granite Dam for individual populations has been highly variable and usually protracted, with timing patterns for some populations ranging from early to late spring. However, shifts in the passage timing distribution for these populations have been less than 1 to 5 weeks over all years. Complex yearly interrelationships between flow and climatic conditions are primary factors contributing to passage timing. However, water temperatures in streams above the dam, turbidity, physiological development, variability in stock behavior, fish size, and other yet unknown factors may all contribute substantially to wild smolt passage timing.

As additional environmental monitors, instream PIT-tag monitors, and traps are installed in study streams, we can more accurately monitor fry, parr, and smolt movements out of rearing areas and examine the relationships between these movements and environmental conditions within the streams. Mapped over time, this information, along with weather and climate data, may provide tools for the prediction of movement in different wild fish stocks. Such tools are vital to recovery planning for Pacific salmon species listed as threatened or endangered under the U.S. Endangered Species Act.

\section{ACKNOWLEDGMENTS}

We thank Bonneville Power Administration for funding this project and Richard Nelson, William Muir, Richard Zabel, Jeffery Moser, Steve Brewer, John Ferguson, Lanesa Hodge, Mark Hall, Robert Emmett, Paul Kemp, Darren Ogden, Shane Collier, Richard Ledgerwood, Michael Gessel, Holly Kenyon, and Colin Christianson for their excellent assistance in collecting and PIT tagging fish for this study. Also, thanks to personnel from the Idaho Department of Fish and Game and the Nez Perce Tribe for providing data from trapping operations in natal rearing areas. Special thanks to William Wassard for the successful maintenance of the instream PIT-tag monitoring systems in lower Valley Creek. 


\section{REFERENCES}

Achord, S., G. A. Axel, E. E. Hockersmith, B. P. Sandford, M. B. Eppard, and G. M. Matthews. 2001a. Monitoring the migrations of wild Snake River spring/summer Chinook salmon smolts, 1999. Report to Bonneville Power Administration, Project 91-028, Contract 99-AI-19164. 87 p. (Available www.efw.bpa.gov)

Achord, S., G. A. Axel, E. E. Hockersmith, B. P. Sandford, M. B. Eppard, and G. M. Matthews. 2001b. Monitoring the migrations of wild Snake River spring/summer Chinook salmon smolts, 2000. Report to Bonneville Power Administration, Project 91-028, Contract 99-AI-19164. 104 p. (Available on the Internet at www.efw.bpa.gov/searchpublications/).

Achord, S., G. A. Axel, E. E. Hockersmith, B. P. Sandford, M. B. Eppard, and G. M. Matthews. 2002. Monitoring the migrations of wild Snake River spring/summer Chinook salmon smolts, 2001. Report to Bonneville Power Administration, Project 91-028, Contract 00005619. 74 p. (Available on the Internet at www.efw.bpa.gov/searchpublications/).

Achord, S., M. B. Eppard, E. E. Hockersmith, B. P. Sandford, G. A. Axel, and G. M. Matthews. 2000. Monitoring the migrations of wild Snake River spring/summer Chinook salmon smolts, 1998. Report to Bonneville Power Administration, Project 9102800, Contract DE-AI79-91BP18800. 82 p. (Available www.efw.bpa.gov/searchpublications/).

Achord, S., M. B. Eppard, E. E. Hockersmith, B. P. Sandford, and G. M. Matthews. 1997. Monitoring the migrations of wild Snake River spring/summer Chinook salmon smolts, 1996. Report to Bonneville Power Administration, Project 91-028, Contract DE-AI79-91BP18800. 74 p. (Available from Northwest Fisheries Science Center, 2725 Montlake Blvd. E., Seattle, WA 98112-2097.)

Achord, S., M. B. Eppard, E. E. Hockersmith, B. P. Sandford, and G. M. Matthews. 1998. Monitoring the migrations of wild Snake River spring/summer Chinook salmon smolts, 1997. Report to Bonneville Power Administration, Project 91028, Contract DE-AI79-91BP18800. 78 p. (Available on the Internet at www.efw.bpa.gov/searchpublications/). 
Achord, S., M. B. Eppard, B. P. Sandford, and G. M. Matthews. 1996a. Monitoring the migrations of wild Snake River spring/summer Chinook salmon smolts, 1995. Report to Bonneville Power Administration, Project 91-028, Contract DE-AI7991BP18800. 179 p. (Available from Northwest Fisheries Science Center, 2725 Montlake Blvd. E., Seattle, WA 98112-2097.)

Achord, S., J. R. Harmon, D. M. Marsh, B. P. Sandford, K. W. McIntyre, K. L. Thomas, N. N. Paasch, and G. M. Matthews. 1992. Research related to transportation of juvenile salmonids on the Columbia and Snake Rivers, 1991. Report to U.S. Army Corps of Engineers, Contract DACW68-84-H0034. 57 p. plus appendix. (Available from Northwest Fisheries Science Center, 2725 Montlake Blvd. E., Seattle, WA 98112-2097.)

Achord, S., E. E. Hockersmith, B. P. Sandford, R. A. McNatt, B. E. Feist, and G. M. Matthews. 2003. Monitoring the migrations of wild Snake River spring/summer Chinook salmon smolts, 2002. Report to Bonneville Power Administration, Project 199102800, Contract 00005619. 94 p. (Available on the Internet at www.efw.bpa.gov/searchpublications/).

Achord, S., J. M. Hodge, B. P. Sandford, E. E. Hockersmith, K. W. McIntyre, N. N. Paasch, and J. G. Williams. 2005. Monitoring the migrations of wild Snake River spring/summer Chinook salmon smolts, 2004. Report to Bonneville Power Administration, Project 199102800, Contract 00005619. 94 p. (Available on the Internet at www.efw.bpa.gov/searchpublications/).

Achord, S., D. J. Kamikawa, B. P. Sandford, and G. M. Matthews. 1995a. Monitoring the migrations of wild Snake River spring/summer Chinook salmon smolts, 1993. Report to Bonneville Power Administration, Project 91-028, Contract DE-AI7991BP18800. 88 p. (Available from Northwest Fisheries Science Center, 2725 Montlake Blvd. E., Seattle, WA 98112-2097.)

Achord, S., D. J. Kamikawa, B. P. Sandford, and G. M. Matthews. 1995b. Monitoring the migrations of wild Snake River spring/summer Chinook salmon smolts, 1994. Report to Bonneville Power Administration, Project 91-028, Contract DE-AI7991BP18800. 100 p. (Available from Northwest Fisheries Science Center, 2725 Montlake Blvd. E., Seattle, WA 98112-2097.)

Achord, S., G. M. Matthews, O. W. Johnson, and D. M. Marsh. 1996b. Use of Passive Integrated Transponder (PIT) tags to monitor migration timing of Snake River Chinook salmon smolts. N. Am. J. Fish. Manage. 16:302-313. 
Achord, S., G. M. Matthews, D. M. Marsh, B. P. Sandford, and D. J. Kamikawa. 1994. Monitoring the migrations of wild Snake River spring and summer Chinook salmon smolts, 1992. Report to Bonneville Power Administration, Project 91-028, Contract DE-AI79-91BP18800. 73 p. (Available from Northwest Fisheries Science Center, 2725 Montlake Blvd. E., Seattle, WA 98112-2097.)

Achord, S., R. A. McNatt, E. E. Hockersmith, B. P. Sandford, K. W. McIntyre, N. N. Paasch, J. G. Williams, and G. M. Matthews. 2004. Monitoring the migrations of wild Snake River spring/summer Chinook salmon smolts, 2003. Report to Bonneville Power Administration, Project 199102800, Contract 00005619. 98 p. (Available on the Internet at www.efw.bpa.gov/searchpublications/).

Downing, S. L., E. F. Prentice, B. W. Peterson, E. P. Nunnallee, and B. F. Jonasson. 2001. Development and evaluation of passive integrated transponder tag technology, annual report: 1999 to 2000. Report to Bonneville Power Administration, project 83-319, contract 307-0001. (Available on the Internet at http://www.efw.bpa.gov/searchpublications/).

Efron, B., and R. J. Tibshirani. 1993. An introduction to the bootstrap. Chapman and Hall, Norwell, MA, 436 p.

Ledgerwood, R. D., B. A. Ryan, E. M. Dawley, E. P. Nunnallee, and J. W. Ferguson. 2004. A surface trawl to detect migrating juvenile salmonids tagged with passive integrated transponder tags. North American Journal of Fisheries Management 24:440-451.

Matthews, G. M., J. R. Harmon, S. Achord, O. W. Johnson, and L. A. Kubin. 1990. Evaluation of transportation of juvenile salmonids and related research on the Snake and Columbia Rivers, 1989. Report to U.S. Army Corp of Engineers, Contract DACW68-84-H0034. 59 p. plus Appendix. (Available from Northwest Fisheries Science Center, 2725 Montlake Blvd. E., Seattle WA 98112-2097.)

PSMFC (Pacific States Marine Fisheries Commission). 1996. The Columbia Basin PIT Tag Information System (PTAGIS). PSMFC, Portland, Oregon. Online database available through the internet at http://www.psmfc.org.pittag/ (accessed October 2004).

Petersen, R. G. 1985. Design and analysis of experiments. Marcel Dekker, New York, $429 \mathrm{p}$. 
Prentice, E. F., T. A. Flagg, and C. S. McCutcheon. 1990. PIT-tag monitoring systems for hydroelectric dams and fish hatcheries. Am. Fish. Soc. Symp. 7:323-334.

Sandford, B. P., and S. G. Smith. 2002. Estimation of smolt-to-adult return percentages for Snake River Basin anadromous salmonids, 1990-1997. J. Agric. Biol. Environ. Stat. 7(2):243-263. 


\section{APPENDIX}

Data Tables and Figures 
Appendix Table 1a. Accumulated and 2005 passage dates at Lower Granite Dam for PIT-tagged wild spring/summer Chinook salmon smolts from streams in Idaho.

\begin{tabular}{|c|c|c|c|c|}
\hline \multirow[b]{2}{*}{ Year } & \multicolumn{4}{|c|}{ Percentile passage dates at Lower Granite Dam } \\
\hline & 10th & 50 th & 90th & Range \\
\hline \multicolumn{5}{|c|}{ Bear Valley Creek } \\
\hline $1990^{\mathrm{a}}$ & 19 April & 05 May & 31 May & 11 April-18 July \\
\hline 1991 & 03 May & 20 May & 12 June & 18 April-23 June \\
\hline 1992 & 15 April & 02 May & 24 May & 07 April-28 June \\
\hline 1993 & 29 April & 16 May & 22 June & 22 April-27 July \\
\hline 1994 & 22 April & 06 May & 29 May & 16 April-15 July \\
\hline 1995 & 28 April & 18 May & 12 June & 13 April-20 July \\
\hline $1996-1997^{\mathrm{a}}$ & --- & --- & --- & --- \\
\hline 1998 & 25 April & 06 May & 23 May & 31 March-25 June \\
\hline 1999 & 23 April & 03 May & 07 June & 20 April-21 June \\
\hline 2000 & 18 April & 07 May & 02 June & 14 April-02 July \\
\hline 2001 & 08 May & 16 May & 28 May & 26 April-17 June \\
\hline 2002 & 16 April & 04 May & 31 May & 12 April-26 June \\
\hline 2003 & 14 April & 05 May & 28 May & 12 April-14 June \\
\hline 2004 & 15 April & 07 May & 28 May & 13 April-05 July \\
\hline 2005 & 20 April & 05 May & 23 May & 20 April-10 June \\
\hline \multicolumn{5}{|l|}{ Elk Creek } \\
\hline $1990^{\mathrm{a}}$ & --- & --- & --- & --- \\
\hline 1991 & 03 May & 20 May & 16 June & 25 April-24 June \\
\hline 1992 & 11 April & 30 April & 28 May & 05 April-17 July \\
\hline 1993 & 02 May & 16 May & 11 June & 21 April-26 June \\
\hline 1994 & 23 April & 04 May & 21 May & 18 April-09 July \\
\hline 1995 & 18 April & 11 May & 05 June & 10 April-09 July \\
\hline $1996-1997^{\mathrm{a}}$ & --- & --- & --- & --- \\
\hline 1998 & 07 April & 02 May & 15 May & 04 April-21 June \\
\hline 1999 & 21 April & 03 May & 27 May & 01 April-08 July \\
\hline 2000 & 15 April & 28 April & 19 May & 13 April-28 May \\
\hline 2001 & 30 April & 11 May & 27 May & 30 April-27 May \\
\hline 2002 & 16 April & 29 April & 02 June & 13 April-05 July \\
\hline 2003 & 20 April & 06 May & 29 May & 31 March-30 May \\
\hline 2004 & 18 April & 08 May & 04 July & 14 April-July 12 \\
\hline 2005 & 27 April & 11 May & 29 May & 18 April-12 June \\
\hline \multicolumn{5}{|c|}{ Sulphur Creek } \\
\hline 1990 & 18 April & 30 April & 31 May & 11 April-27 June \\
\hline $1991^{\mathrm{a}}$ & --- & --- & --- & --- \\
\hline 1992 & 16 April & 03 May & 23 May & 10 April-01 June \\
\hline 1993 & 28 April & 16 May & 12 June & 24 April-28 June \\
\hline $1994^{\mathrm{a}}$ & --- & --- & --- & --- \\
\hline 1995 & 02 May & 23 May & 09 June & 11 April-09 July \\
\hline $1996^{\mathrm{a}}$ & --- & --- & --- & --- \\
\hline $1997^{\mathrm{a}}$ & --- & --- & --- & --- \\
\hline
\end{tabular}


Appendix Table 1a. Continued.

\begin{tabular}{|c|c|c|c|c|}
\hline \multirow[b]{2}{*}{ Year } & \multicolumn{4}{|c|}{ Percentile passage dates at Lower Granite Dam } \\
\hline & 10 th & 50 th & 90th & Range \\
\hline \multicolumn{5}{|c|}{ Sulphur Creek(Continued) } \\
\hline 1998 & -- & --- & --- & --- \\
\hline 1999 & 24 April & 19 May & 27 May & 22 April-29 may \\
\hline 2000 & 15 April & 07 May & 24 May & 12 April-30 May \\
\hline $2001-2002^{\mathrm{a}}$ & --- & --- & --- & --- \\
\hline 2003 & 02 May & 25 May & 08 May & 22 April-24 June \\
\hline 2004 & 10 April & 25 April & 11 May & 02 April-24 May \\
\hline 2005 & 01 May & 07 May & 22 May & 22 April-5 June \\
\hline \multicolumn{5}{|c|}{ Cape Horn Creek } \\
\hline $1990^{\mathrm{a}}$ & --- & --- & --- & --- \\
\hline 1991 & 24 April & 16 May & 28 May & 19 April-06 June \\
\hline 1992 & 12 April & 28 April & 30 May & 10 April-01 June \\
\hline 1993 & 08 May & 19 May & 26 June & 05 May-01 July \\
\hline $1994^{\mathrm{a}}$ & --- & --- & --- & --- \\
\hline 1995 & 29 April & 14 May & 19 June & 14 April-28 July \\
\hline $1996^{\mathrm{a}}$ & --- & --- & --- & --- \\
\hline $1997^{\mathrm{a}}$ & --- & --- & --- & --- \\
\hline $1998^{\mathrm{a}}$ & --- & --- & --- & --- \\
\hline 1999 & 29 April & 22 May & 29 May & 25 April-12 June \\
\hline 2000 & 01 May & 24 May & 01 June & 20 April-09 July \\
\hline $2001-2002^{\mathrm{a}}$ & --- & --- & --- & --- \\
\hline 2003 & 21 April & 17 May & 01 June & 15 April-18 June \\
\hline 2004 & 15 April & 04 May & 24 May & 14 April-28 May \\
\hline 2005 & 29 April & 09 May & 24 May & 11 April-29 May \\
\hline \multicolumn{5}{|c|}{ Camas Creek } \\
\hline 1993 & 03 May & 16 May & 27 May & 24 April-24 June \\
\hline 1994 & 30 April & 15 May & 26 May & 24 April-11 July \\
\hline 1995 & 27 April & 12 May & 05 June & 17 April-11 June \\
\hline $1996^{\mathrm{a}}$ & --- & --- & --- & --- \\
\hline $1997^{\mathrm{a}}$ & --- & --- & --- & --- \\
\hline $1998^{\mathrm{a}}$ & --- & --- & --- & --- \\
\hline $1999^{\mathrm{a}}$ & --- & --- & --- & --- \\
\hline 2000 & 26 April & 25 May & 02 June & 13 April-24 June \\
\hline 2001a 2002a & --- & --- & --- & --- \\
\hline 2003 & 02 May & 24 May & 30 May & 26 April-06 June \\
\hline 2004 & 18 April & 08 May & 24 May & 16 April-04 June \\
\hline 2005 & 29 April & 07 May & 28 May & 12 April-19 June \\
\hline \multicolumn{5}{|l|}{ Marsh Creek } \\
\hline 1990 & 17 April & 29 April & 31 May & 09 April-01 July \\
\hline 1991 & 26 April & 20 May & 09 June & 17 April-18 June \\
\hline 1992 & 17 April & 07 May & 02 June & 10 April-13 July \\
\hline
\end{tabular}


Appendix Table 1a. Continued.

\begin{tabular}{|c|c|c|c|c|}
\hline \multirow[b]{2}{*}{ Year } & \multicolumn{4}{|c|}{ Percentile passage dates at Lower Granite Dam } \\
\hline & 10th & 50 th & 90th & Range \\
\hline \multicolumn{5}{|c|}{ Marsh Creek (Continued) } \\
\hline 1993 & 29 April & 15 May & 27 May & 24 April-10 August \\
\hline 1994 & 23 April & 04 May & 18 May & 16 April-08 August \\
\hline 1995 & 17 April & 09 May & 24 May & 11 April-08 July \\
\hline $1996^{\mathrm{a}}$ & --- & --- & --- & -- \\
\hline $1997^{\mathrm{a}}$ & --- & --- & --- & --- \\
\hline $1998^{\mathrm{a}}$ & --- & --- & --- & --- \\
\hline 1999 & 21 April & 01 May & 25 May & 11 April-13 June \\
\hline 2000 & 21 April & 28 April & 27 May & 14 April-16 June \\
\hline $2001^{\mathrm{a}}$ & --- & --- & --- & -- \\
\hline 2002 & 18 April & 04 May & 23 May & 14 April-26 May \\
\hline 2003 & 14 April & 05 May & 29 May & 03 April-09 June \\
\hline 2004 & 16 April & 28 April & 10 May & 03 April-30 May \\
\hline 2005 & 27 April & 06 May & 18 May & 22 April-04 June \\
\hline \multicolumn{5}{|c|}{ Valley Creek } \\
\hline 1989 & 24 April & 14 May & 12 June & 09 April-17 June \\
\hline 1990 & 16 April & 08 May & 05 June & 12 April-29 June \\
\hline 1991 & 11 May & 20 May & 20 June & 21 April-13 July \\
\hline 1992 & 15 April & 30 April & 27 May & 13 April-04 June \\
\hline 1993 & 30 April & 16 May & 02 June & 24 April-06 June \\
\hline 1994 & 24 April & 04 May & 03 June & 22 April-09 June \\
\hline 1995 & 04 May & 02 June & 08 July & 22 April-18 July \\
\hline $1996-1998^{a}$ & --- & --- & --- & -- \\
\hline 1999 & 24 April & 13 May & 12 June & 19 April-01 July \\
\hline 2000 & 20 April & 12 May & 29 May & 13 April-14 July \\
\hline 2001 & 10 May & 19 May & 01 June & 28 April-03 July \\
\hline 2002 & 24 April & 20 May & 03 June & 19 April-19 June \\
\hline 2003 & 14 April & 17 May & 28 May & 01 April-31 May \\
\hline 2004 & 25 April & 11 May & 26 May & 04 April-16 June \\
\hline 2005 & 27 April & 15 May & 08 June & 23 April-20 June \\
\hline \multicolumn{5}{|l|}{ Loon Creek } \\
\hline 1993 & 05 May & 12 May & 17 May & 03 May-5 June \\
\hline 1994 & 29 April & 10 May & 24 May & 22 April-07 June \\
\hline 1995 & 23 April & 11 May & 28 May & 13 April-07 June \\
\hline $1996^{\mathrm{a}}$ & --- & --- & --- & --- \\
\hline $1997^{\mathrm{a}}$ & --- & --- & --- & --- \\
\hline $1998^{\mathrm{a}}$ & --- & --- & --- & --- \\
\hline 1999 & 30 April & 18 May & 27 May & 22 April-16 June \\
\hline 2000 & 22 April & 08 May & 24 May & 14 April-01 June \\
\hline $2001-2002^{\mathrm{a}}$ & --- & --- & --- & --- \\
\hline 2003 & 30 April & 17 May & 28 May & 21 April-30 May \\
\hline 2004 & 23 April & 05 May & 15 May & 15 April-26 May \\
\hline 2005 & 04 May & 10 May & 24 May & 20 April-03 June \\
\hline
\end{tabular}


Appendix Table 1a. Continued.

\begin{tabular}{|c|c|c|c|c|}
\hline \multirow[b]{2}{*}{ Year } & \multicolumn{4}{|c|}{ Percentile passage dates at Lower Granite Dam } \\
\hline & 10th & 50 th & 90th & Range \\
\hline \multicolumn{5}{|c|}{ East Fork Salmon River } \\
\hline 1989 & 22 April & 03 May & 18 May & 07 April-08 June \\
\hline $1990^{\mathrm{a}}$ & --- & --- & --- & - \\
\hline 1991 & 22 April & 09 May & 26 May & 16 April-20 June \\
\hline 1992 & 13 April & 21 April & 16 May & 10 April-03 June \\
\hline 1993 & 25 April & 06 May & 18 May & 22 April-01 June \\
\hline 1994 & 22 April & 28 April & 17 May & 20 April-25 May \\
\hline 1995 & 14 April & 28 April & 10 May & 11 April-27 May \\
\hline $1996^{\mathrm{a}}$ & --- & --- & --- & -- \\
\hline $1997^{\mathrm{a}}$ & --- & --- & --- & --- \\
\hline $1998^{\mathrm{a}}$ & --- & --- & --- & --- \\
\hline $1999^{\mathrm{a}}$ & --- & --- & --- & --- \\
\hline 2000 & 21 April & 07 May & 25 May & 15 April-27 May \\
\hline $2001^{\mathrm{a}}$ & --- & --- & --- & --- \\
\hline $2002^{a}$ & --- & --- & --- & --- \\
\hline $2003^{\mathrm{a}}$ & --- & --- & --- & --- \\
\hline $2004-2005^{\mathrm{a}}$ & --- & --- & --- & --- \\
\hline \multicolumn{5}{|l|}{ Herd Creek } \\
\hline 1992 & 14 April & 20 April & 10 May & 13 April-18 May \\
\hline 1993 & 26 April & 30 April & 18 May & 26 April-31 May \\
\hline $1994^{b}$ & --- & --- & --- & -- \\
\hline 1995 & 18 April & 03 May & 14 May & 11 April-28 May \\
\hline $1996-1998^{\mathrm{a}}$ & --- & --- & --- & --- \\
\hline 1999 & 20 April & 29 April & 10 May & 30 March-20 May \\
\hline 2000 & 16 April & 25 April & 18 May & 14 April-19 May \\
\hline 2001 & 30 April & 04 May & 14 May & 28 April-07 June \\
\hline $2002^{b}$ & --- & --- & --- & --- \\
\hline 2003 & 16 April & 03 May & 26 May & 06 April-29 May \\
\hline 2004 & 16 April & 30 April & 10 May & 12 April-21 June \\
\hline 2005 & 27 April & 07 May & 22 May & 20 April-13 June \\
\hline \multicolumn{5}{|c|}{ South Fork Salmon River } \\
\hline 1989 & 25 April & 13 May & 14 June & 16 April-20 June \\
\hline $1990^{\mathrm{a}}$ & --- & --- & --- & --- \\
\hline 1991 & 20 April & 16 May & 10 June & 17 April-13 July \\
\hline 1992 & 14 April & 29 April & 27 May & 07 April-27 July \\
\hline 1993 & 29 April & 16 May & 02 June & 26 April-28 June \\
\hline 1994 & 27 April & 15 May & 28 June & 22 April-09 July \\
\hline 1995 & 20 April & 10 May & 10 June & 13 April-13 July \\
\hline 1996 & 19 April & 15 May & 09 June & 19 April-03 July \\
\hline 1997 & 13 April & 28 April & 12 June & 07 April-15 June \\
\hline 1998 & 25 April & 12 May & 15 June & 02 April-07 August \\
\hline 1999 & 31 March & 04 May & 01 June & 27 March-11 June \\
\hline
\end{tabular}


Appendix Table 1a. Continued.

\begin{tabular}{|c|c|c|c|c|}
\hline \multirow[b]{2}{*}{ Year } & \multicolumn{4}{|c|}{ Percentile passage dates at Lower Granite Dam } \\
\hline & 10th & 50th & 90th & Range \\
\hline \multicolumn{5}{|c|}{ South Fork Salmon River (continued) } \\
\hline 2000 & 20 April & 18 May & 31 May & 12 April-20 July \\
\hline 2001 & 29 April & 14 May & 01 June & 26 April-07 July \\
\hline 2002 & 15 April & 03 May & 24 May & 11 April-09 June \\
\hline 2003 & 19 April & 16 May & 03 June & 19 April-12 June \\
\hline 2004 & 16 April & 10 May & 02 June & 08 April-19 June \\
\hline 2005 & 28 April & 12 May & 30 May & 22 April-19 June \\
\hline \multicolumn{5}{|c|}{ Big Creek (upper) } \\
\hline 1990 & 27 April & 30 May & 22 June & 17 April-18 July \\
\hline 1991 & 18 May & 10 June & 26 June & 26 April-01 July \\
\hline 1992 & 22 April & 08 May & 03 June & 15 April-26 June \\
\hline 1993 & 08 May & 18 May & 26 May & 26 April-15 June \\
\hline 1994 & 03 May & 19 May & 19 July & 25 April-30 August \\
\hline 1995 & 05 May & 23 May & 09 June & 02 May-26 June \\
\hline 1996-1998a & --- & --- & --- & --- \\
\hline 1999 & 28 April & 14 May & 03 June & 25 April-19 June \\
\hline 2000 & 30 April & 27 May & 14 June & 15 April-29 June \\
\hline $2001^{\mathrm{a}}$ & -- & -- & --- & -- \\
\hline $2002^{\mathrm{a}}$ & --- & --- & --- & --- \\
\hline 2003 & 06 May & 25 May & 01 June & 01 May-21 June \\
\hline 2004 & 18 April & 12 May & 05 May & 15 April-17 June \\
\hline 2005 & 27 April & 07 May & 23 May & 20 April-07 June \\
\hline \multicolumn{5}{|c|}{ Big (lower)/Rush Creeks } \\
\hline 1993 & 24 April & 29 April & 13 May & 21 April-16 May \\
\hline 1994 & 23 April & 29 April & 11 May & 21 April-15 June \\
\hline 1995 & 19 April & 01 May & 14 May & 11 April-05 June \\
\hline $1996^{\mathrm{a}}$ & --- & --- & --- & --- \\
\hline $1997^{\mathrm{a}}$ & -- & -- & -- & --- \\
\hline $1998^{a}$ & --- & --- & --- & --- \\
\hline 1999 & 19 April & 28 April & 23 May & 04 April-30 May \\
\hline 2000 & 19 April & 30 April & 13 May & 16 April-26 May \\
\hline $2001^{\mathrm{a}}$ & --- & --- & --- & -- \\
\hline 2002 & 15 April & 25 April & 07 May & 12 April-22 May \\
\hline 2003 & 14 April & 26 April & 18 May & 12 April-25 May \\
\hline 2004 & 15 April & 23 April & 04 May & 06 April-15 May \\
\hline $2005^{\mathrm{d}}$ & 22 April & 02 May & 09 May & 06 April-15 May \\
\hline \multicolumn{5}{|c|}{ West Fork Chamberlain Creek } \\
\hline $1992^{c}$ & 15 April & 26 April & 03 June & 12 April-24 June \\
\hline 1993 & 28 April & 15 May & 23 June & 23 April-22 July \\
\hline $1994^{\mathrm{c}}$ & 24 April & 01 May & 05 July & 24 April-04 September \\
\hline $1995^{\mathrm{c}}$ & 16 April & 09 May & 20 June & 12 April-22 September \\
\hline
\end{tabular}


Appendix Table 1a. Continued.

\begin{tabular}{|c|c|c|c|c|}
\hline \multirow[b]{2}{*}{ Year } & \multicolumn{4}{|c|}{ Percentile passage dates at Lower Granite Dam } \\
\hline & 10th & 50th & 90th & Range \\
\hline \multicolumn{5}{|c|}{ West Fork Chamberlain Creek (continued) } \\
\hline $1996^{\mathrm{a}}$ & --- & -- & --- & --- \\
\hline $1997^{\mathrm{a}}$ & --- & --- & --- & --- \\
\hline $1998^{\mathrm{a}}$ & --- & --- & --- & --- \\
\hline $1999^{\mathrm{a}}$ & --- & --- & --- & --- \\
\hline $2000^{\mathrm{a}}$ & --- & --- & --- & --- \\
\hline $2001^{\mathrm{a}}$ & --- & --- & --- & --- \\
\hline 2002 & 26 April & 04 May & 20 May & 18 April-29 May \\
\hline $2003^{c}$ & 23 April & 20 May & 26 May & 21 April-26 May \\
\hline $2004^{\mathrm{c}}$ & 11 April & 24 April & 10 May & 07 April-23 June \\
\hline $2005^{\mathrm{c}}$ & 26 April & 03 May & 13 May & 20 April-30 May \\
\hline \multicolumn{5}{|c|}{ Secesh River } \\
\hline 1989 & 20 April & 27 April & 09 June & 09 April-19 July \\
\hline 1990 & 14 April & 22 April & 07 June & 10 April-13 July \\
\hline 1991 & 20 April & 27 April & 14 June & 13 April-20 July \\
\hline 1992 & 13 April & 29 April & 04 June & 05 April-03 July \\
\hline 1993 & 26 April & 16 May & 16 June & 22 April-15 July \\
\hline 1994 & 22 April & 26 April & 11 July & 21 April-07 August \\
\hline 1995 & 14 April & 01 May & 24 May & 10 April-10 July \\
\hline 1996 & 14 April & 25 April & 29 May & 12 April-15 July \\
\hline 1997 & 10 April & 18 April & 04 May & 04 April-11 July \\
\hline 1998 & 08 April & 24 April & 28 May & 03 April-06 July \\
\hline 1999 & 03 April & 23 April & 25 May & 29 March-21 June \\
\hline 2000 & 13 April & 23 April & 04 June & 12 April-11 July \\
\hline 2001 & 16 April & 28 April & 13 May & 06 April-13 June \\
\hline 2002 & 13 April & 21 April & 17 May & 11 April-01 July \\
\hline 2003 & 18 April & 30 April & 01 June & 03 April-04 July \\
\hline 2004 & 04 April & 27 April & 28 May & 01 April-13 June \\
\hline 2005 & 23 April & 03 May & 26 May & 04 April-19 June \\
\hline \multicolumn{5}{|c|}{ Lake Creek } \\
\hline 1989 & 23 April & 02 May & 16 June & 12 April-01 July \\
\hline $1990^{\mathrm{a}}$ & --- & --- & --- & --- \\
\hline $1991^{\mathrm{a}}$ & --- & --- & --- & --- \\
\hline $1992^{\mathrm{a}}$ & --- & --- & --- & --- \\
\hline 1993 & 23 April & 09 May & 22 June & 22 April-25 June \\
\hline 1994 & 21 April & 28 April & 19 May & 20 April-24 June \\
\hline 1995 & 17 April & 10 May & 10 June & 14 April-20 July \\
\hline 1996 & 15 April & 21 April & 19 May & 15 April-02 June \\
\hline 1997 & 11 April & 25 April & 02 July & 07 April-22 September \\
\hline 1998 & 04 April & 25 April & 26 May & 02 April-16 July \\
\hline 1999 & 20 April & 26 April & 27 May & 08 April-20 June \\
\hline 2000 & 13 April & 04 May & 04 June & 13 April-18 July \\
\hline
\end{tabular}


Appendix Table 1a. Continued.

\begin{tabular}{lcccc}
\hline & \multicolumn{3}{c}{ Percentile passage dates at Lower Granite Dam } \\
\cline { 2 - 5 } Year & 10 th & 50th & 90th & Range \\
\hline Lake Creek (continued) & --- & --- & --- & -- \\
$2001^{\text {a }}$ & - & 03 June & 13 April-03 June \\
2002 & 16 April & 29 April & 04 June & 06 April-20 June \\
2003 & 06 April & 06 May & 28 May & 09 April-16 June \\
2004 & 14 April & 25 April & 29 May & 19 April-19 June \\
2005 & 20 April & 28 April & & \\
\hline
\end{tabular}

a No parr were tagged the summer prior to this migration year.

$\mathrm{b}$ Insufficient numbers detected to estimate timing.

c Includes fish from Chamberlain Creek.

d No fish were tagged in Rush Creek for this migration year. 
Appendix Table 1b. Accumulated and 2005 passage dates at Lower Granite Dam for PIT-tagged wild spring/summer Chinook salmon smolts from streams in Oregon.

\begin{tabular}{|c|c|c|c|c|}
\hline \multirow[b]{2}{*}{ Year } & \multicolumn{4}{|c|}{ Percentile passage dates at Lower Granite Dam } \\
\hline & 10th & 50 th & 90th & Range \\
\hline \multicolumn{5}{|l|}{ Catherine Creek } \\
\hline 1991 & 01 May & 14 May & 08 June & 17 April-23 June \\
\hline 1992 & 16 April & 01 May & 21 May & 09 April-29 June \\
\hline 1993 & 06 May & 18 May & 05 June & 29 April-26 June \\
\hline 1994 & 25 April & 11 May & 20 May & 13 April-26 July \\
\hline 1995 & 01 May & 19 May & 09 June & 26 April-02 July \\
\hline $1996^{\mathrm{a}}$ & 19 April & 13 May & 29 May & 14 April-14 June \\
\hline 1997 & 08 May & 14 May & 01 June & 24 April-10 June \\
\hline 1998 & 28 April & 21 May & 28 May & 24 April-04 June \\
\hline 1999 & 26 April & 25 May & 15 June & 26 April-26 June \\
\hline 2000 & 30 April & 08 May & 23 May & 12 April-06 June \\
\hline 2001 & 29 April & 17 May & 17 June & 28 April-03 July \\
\hline 2002 & 24 April & 10 May & 18 June & 15 April-01 July \\
\hline 2003 & 26 April & 10 May & 09 June & 14 April-09 June \\
\hline 2004 & 22 April & 15 May & 11 June & 15 April-25 June \\
\hline 2005 & 20 April & 12 May & 23 May & 14 April-02 June \\
\hline \multicolumn{5}{|c|}{ Grande Ronde River (upper) } \\
\hline 1989 & 12 May & 06 June & 19 June & 27 April-22 July \\
\hline $1990^{\mathrm{b}}$ & --- & --- & --- & --- \\
\hline $1991^{b}$ & --- & --- & --- & --- \\
\hline $1992^{b}$ & --- & --- & --- & --- \\
\hline 1993 & 05 May & 16 May & 25 May & 23 April-20 June \\
\hline 1994 & 28 April & 23 May & 07 July & 23 April-29 August \\
\hline 1995 & 27 April & 29 May & 12 June & 12 April-01 July \\
\hline $1996^{\mathrm{c}}$ & 26 April & 17 May & 29 May & 19 April-06 June \\
\hline 1997 through $2005^{\mathrm{b}}$ & --- & --- & --- & --- \\
\hline \multicolumn{5}{|c|}{ Imnaha River (lower) } \\
\hline 1989 & 11 April & 30 April & 11 May & 04 April-05 June \\
\hline 1990 & 10 April & 18 April & 09 May & 05 April-27 May \\
\hline 1991 & 20 April & 01 May & 13 May & 14 April-15 May \\
\hline 1992 & 10 April & 21 April & 03 May & 06 April-21 May \\
\hline 1993 through $2005^{\mathrm{b}}$ & --- & --- & --- & --- \\
\hline \multicolumn{5}{|c|}{ Imnaha River (upper) } \\
\hline 1993 & 24 April & 14 May & 28 May & 15 April-23 June \\
\hline 1994 & 24 April & 08 May & 09 June & 20 April-11 August \\
\hline 1995 & 13 April & 02 May & 03 June & 10 April-07 July \\
\hline 1996 & 16 April & 26 April & 18 May & 14 April-12 June \\
\hline 1997 & 11 April & 19 April & 11 May & 03 April-02 June \\
\hline 1998 & 11 April & 28 April & 13 May & 03 April-24 May \\
\hline
\end{tabular}


Appendix Table 1b. Continued.

\begin{tabular}{|c|c|c|c|c|}
\hline \multirow[b]{2}{*}{ Year } & \multicolumn{4}{|c|}{ Percentile passage dates at Lower Granite Dam } \\
\hline & 10th & 50th & 90th & Range \\
\hline \multicolumn{5}{|c|}{ Imnaha River (upper; continued) } \\
\hline 1999 & 22 April & 08 May & 26 May & 17 April-03 June \\
\hline 2000 & 14 April & 02 May & 24 May & 12 April-16 June \\
\hline 2001 & 21 April & 30 April & 16 May & 08 April-28 May \\
\hline 2002 & 16 April & 04 May & 17 May & 15 April-31 May \\
\hline 2003 & 22 April & 08 May & 26 May & 17 April-31 May \\
\hline 2004 & 19 April & 04 May & 22 May & 18 April-8 June \\
\hline 2005 & 19 April & 03 May & 27 May & 05 April-11 June \\
\hline \multicolumn{5}{|c|}{ Lostine River } \\
\hline $1990^{\mathrm{d}}$ & --- & --- & --- & --- \\
\hline 1991 & 29 April & 14 May & 26 May & 20 April-09 July \\
\hline 1992 & 16 April & 30 April & 11 May & 12 April-02 June \\
\hline 1993 & 23 April & 03 May & 17 May & 17 April-01 June \\
\hline 1994 & 22 April & 30 April & 16 May & 19 April-07 June \\
\hline 1995 & 12 April & 02 May & 17 May & 08 April-09 June \\
\hline 1996 & 23 April & 15 May & 07 June & 17 April-19 June \\
\hline 1997 & 17 April & 28 April & 16 May & 09 April-21 May \\
\hline $1998^{\mathrm{b}}$ & --- & --- & --- & --- \\
\hline 1999 & $30 \mathrm{March}$ & 09 May & 27 May & 29 March-29 May \\
\hline 2000 & 13 April & 08 May & 25 May & 13 April-03 June \\
\hline 2001 & 25 April & 09 May & 22 May & 10 April-12 June \\
\hline 2002 & 11 April & 21 April & 13 May & 28 March-29 May \\
\hline 2003 & 13 April & 08 May & 26 May & 11 April-03 June \\
\hline 2004 & 15 April & 04 May & 05 June & 14 April-15 June \\
\hline 2005 & 16 April & 29 April & 26 May & 05 April-18 June \\
\hline \multicolumn{5}{|c|}{ Minam River } \\
\hline 1999 & 08 April & 28 April & 25 May & 31 March-02 June \\
\hline 2000 & 15 April & 03 May & 22 May & 10 April-29 May \\
\hline 2001 & 25 April & 07 May & 23 May & 08 April-12 June \\
\hline 2002 & 17 April & 03 May & 20 May & 16 April-31 May \\
\hline 2003 & 17 April & 13 May & 29 May & 13 April-01 June \\
\hline 2004 & 15 April & 28 April & 28 May & 08 April-31 May \\
\hline 2005 & 19 April & 08 May & 21 May & 08 April-08 June \\
\hline
\end{tabular}

a Includes fish tagged from summer 1995 through spring 1996.

$\mathrm{b}$ No parr were tagged the summer prior to this migration year.

c All fish tagged at traps in fall or spring for this migration year.

$\mathrm{d}$ Insufficient numbers detected to estimate timing. 
Appendix Table 2. Summary of numbers collected, tagged, and released with minimum, maximum, and mean length and weight of PIT-tagged wild Chinook salmon parr collected in 2004 from Idaho streams.

\begin{tabular}{|c|c|c|c|c|c|c|c|c|c|c|c|}
\hline & \multirow{2}{*}{\multicolumn{3}{|c|}{ Number of fish }} & \multicolumn{4}{|c|}{ Collected } & \multicolumn{4}{|c|}{ Tagged and released } \\
\hline & & & & \multicolumn{2}{|c|}{ Length } & \multicolumn{2}{|c|}{ Weight } & \multicolumn{2}{|c|}{ Length } & \multicolumn{2}{|c|}{ Weight } \\
\hline & Collected & Tagged & Released & Range & Mean & Range & Mean & Range & Mean & Range & Mean \\
\hline Bear Valley Creek & 2,640 & 1,502 & 1,500 & $40-132$ & 56.4 & $0.7-21.9$ & 2.4 & $50-132$ & 59.9 & $1.2-6.0$ & 2.5 \\
\hline Elk Creek & 2,098 & 1,471 & 1,471 & $39-134$ & 58.4 & $0.7-32.0$ & 2.9 & $49-121$ & 61.1 & $1.3-8.6$ & 3.0 \\
\hline Marsh Creek & 2,316 & 1,503 & 1,501 & $39-128$ & 60.4 & $0.9-21.9$ & 3.4 & $50-120$ & 64.7 & $1.1-8.6$ & 3.7 \\
\hline Sulphur Creek & 2,086 & 1,158 & 1,157 & $37-126$ & 55.7 & $0.6-26.0$ & 2.9 & $47-97$ & 61.3 & $1.5-7.7$ & 2.9 \\
\hline Cape Horn Creek & 2,703 & 1,023 & 1,022 & $37-127$ & 53.1 & $0.5-22.7$ & 3.1 & $47-92$ & 61.3 & $1.3-8.6$ & 3.1 \\
\hline Valley Creek & 4,577 & 2,517 & 2,511 & $38-177$ & 57.3 & $0.7-25.6$ & 2.9 & $49-105$ & 63.0 & $1.3-13.5$ & 3.0 \\
\hline Loon Creek & 1,619 & 1,502 & 1,501 & $40-157$ & 61.7 & $1.2-7.0$ & 3.3 & $50-157$ & 62.5 & $1.3-7.0$ & 3.3 \\
\hline Camas Creek & 1,742 & 1,501 & 1,500 & $43-92$ & 60.8 & $1.0-7.7$ & 3.4 & $51-92$ & 62.1 & $1.4-7.7$ & 3.5 \\
\hline Herd Creek & 1,818 & 1,559 & 1,559 & $42-122$ & 64.9 & $0.8-18.1$ & 3.8 & $50-105$ & 66.8 & $1.6-11.1$ & 3.9 \\
\hline Big Creek (upper) & 1,801 & 1,516 & 1,516 & $45-111$ & 63.4 & $1.1-16.4$ & 3.0 & $51-96$ & 63.5 & $1.2-6.9$ & 3.0 \\
\hline Big Creek (lower) & 393 & 375 & 374 & $55-94$ & 71.1 & $1.9-8.2$ & 4.2 & $55-94$ & 71.2 & $1.9-8.2$ & 4.2 \\
\hline WF Chamberlain $\mathrm{Cr}$ & r 1,039 & 1,033 & 1,030 & $49-130$ & 66.1 & $1.1-15.4$ & 3.4 & $51-84$ & 66.0 & $1.6-8.0$ & 3.4 \\
\hline Chamberlain Creek & 355 & 298 & 298 & $46-110$ & 60.0 & $1.6-5.5$ & 3.0 & $52-78$ & 61.0 & $1.7-5.5$ & 3.0 \\
\hline S Fork Salmon R & 2,489 & 1,225 & 1,222 & $37-125$ & 56.1 & $0.8-20.6$ & 2.8 & $49-98$ & 61.4 & $1.4-11.2$ & 2.7 \\
\hline Secesh River & 1,506 & 1,075 & 1,074 & $39-100$ & 59.9 & $1.0-8.6$ & 2.8 & $54-100$ & 62.8 & $1.5-8.6$ & 2.9 \\
\hline Lake Creek & 972 & 650 & 650 & $41-97$ & 58.7 & $0.5-7.2$ & 2.8 & $52-97$ & 62.2 & $1.7-7.2$ & 3.0 \\
\hline Total or mean & 30,154 & 19,908 & 19,886 & $37-177$ & 60.2 & $0.5-32.0$ & 3.1 & $47-157$ & 63.2 & $1.1-13.5$ & 3.2 \\
\hline
\end{tabular}


Appendix Table 3a. Tagging dates, times (PST) and temperatures $\left({ }^{\circ} \mathrm{C}\right)$ and release dates, times, and temperatures. Also presented are methods of capture and distance $(\mathrm{km})$ from the mouth of the stream to the release point, number released in 2004, and number/percent of first-time detections (unadjusted) for each tag group at seven downstream dams and in the surface-trawl detector in the upper Columbia River estuary during 2005.

\begin{tabular}{|c|c|c|c|c|c|c|c|c|c|c|c|}
\hline \multirow[b]{2}{*}{ Group } & \multicolumn{3}{|c|}{ Tagging } & \multirow{2}{*}{$\begin{array}{l}\text { Capture } \\
\text { method }\end{array}$} & \multicolumn{3}{|c|}{ Release } & \multirow{2}{*}{$\begin{array}{c}\text { Stream } \\
\text { distance } \\
(\mathrm{km})\end{array}$} & \multirow{2}{*}{$\begin{array}{c}\text { Released } \\
\text { (n) }\end{array}$} & \multicolumn{2}{|c|}{ Detected } \\
\hline & Date & Time & Temp $\left({ }^{\circ} \mathrm{C}\right)$ & & Date & Time & Temp $\left({ }^{\circ} \mathrm{C}\right)$ & & & (n) & $(\%)$ \\
\hline \multicolumn{12}{|c|}{ Bear Valley Creek } \\
\hline SA04203.BV1 & $7 / 21$ & 0637 & 13.0 & B Seine & $7 / 22$ & 0600 & 12.5 & 09 & 141 & 3 & 2.1 \\
\hline SA04203.BV2 & $7 / 21$ & 0818 & 13.5 & B Seine & $7 / 21$ & 0818 & 15.0 & 10 & 115 & 4 & 3.5 \\
\hline SA04203.BV3 & $7 / 21$ & 1019 & 14.5 & Shock & $7 / 21$ & 1115 & 16.0 & 10 & 211 & 10 & 4.7 \\
\hline SA04204.BV1 & $7 / 22$ & 0631 & 12.5 & B Seine & $7 / 22$ & 1100 & 15.5 & 10 & 727 & 23 & 3.2 \\
\hline SA04205.BV1 & $7 / 23$ & 0553 & 12.5 & B Seine & $7 / 23$ & 0815 & 13.5 & 14 & 306 & 14 & 4.6 \\
\hline \multicolumn{12}{|l|}{ Elk Creek } \\
\hline SA04205.EC1 & $7 / 23$ & 0807 & 13.0 & B Seine & $7 / 24$ & 0730 & 15.0 & 01 & 197 & 15 & 7.6 \\
\hline SA04205.EC2 & $7 / 23$ & 0923 & 13.5 & B Seine & $7 / 23$ & 1100 & 15.0 & 01 & 430 & 30 & 7.0 \\
\hline SA04208.EC1 & $7 / 26$ & 0633 & 13.0 & B Seine & $7 / 26$ & 0800 & 14.0 & 02 & 25 & 1 & 4.0 \\
\hline SA04208.EC2 & $7 / 26$ & 0725 & 13.0 & Shock & $7 / 26$ & 1100 & 16.0 & 02 & 482 & 15 & 3.1 \\
\hline SA04209.EC1 & $7 / 27$ & 0602 & 12.5 & Shock & $7 / 27$ & 1000 & 14.0 & 04 & 337 & 20 & 5.9 \\
\hline \multicolumn{12}{|l|}{ Marsh Creek } \\
\hline SA04210.MC1 & $7 / 28$ & 0726 & 09.0 & B Seine & $7 / 29$ & 0509 & 09.0 & 11 & 110 & 7 & 6.4 \\
\hline SA04210.MC2 & $7 / 28$ & 0850 & 10.0 & B Seine & $7 / 28$ & 1200 & 16.0 & 11 & 552 & 35 & 6.3 \\
\hline SA04211.MC1 & $7 / 29$ & 0604 & 08.0 & B Seine & $7 / 29$ & 1210 & 15.0 & 14 & 839 & 62 & 7.4 \\
\hline
\end{tabular}


Appendix Table 3a. Continued.

\begin{tabular}{|c|c|c|c|c|c|c|c|c|c|c|c|}
\hline \multirow[b]{2}{*}{ Group } & \multicolumn{3}{|c|}{ Tagging } & \multirow{2}{*}{$\begin{array}{l}\text { Capture } \\
\text { method }\end{array}$} & \multicolumn{3}{|c|}{ Release } & \multirow{2}{*}{$\begin{array}{c}\text { Stream } \\
\text { distance } \\
(\mathrm{km})\end{array}$} & \multirow[b]{2}{*}{ Released (n) } & \multicolumn{2}{|c|}{ Detected } \\
\hline & Date & Time & Temp $\left({ }^{\circ} \mathrm{C}\right)$ & & Date & Time & Temp $\left({ }^{\circ} \mathrm{C}\right)$ & & & (n) & $(\%)$ \\
\hline \multicolumn{12}{|c|}{ Cape Horn Creek } \\
\hline SA04212.CH1 & $7 / 30$ & 0630 & 07.0 & Shock & $7 / 31$ & 0445 & 07.0 & 01 & 139 & 9 & 6.5 \\
\hline SA04212.CH2 & $7 / 30$ & 0911 & 08.0 & Shock & $7 / 30$ & 1230 & 14.5 & 01 & 350 & 24 & 6.9 \\
\hline SA04213.CH1 & $7 / 31$ & 0606 & 07.0 & Shock & $7 / 31$ & 1000 & 09.0 & 03 & 532 & 30 & 5.6 \\
\hline \multicolumn{12}{|l|}{ Sulphur Creek } \\
\hline SA04210.SU1 & $7 / 28$ & 0814 & 10.0 & B Seine & $7 / 29$ & 0630 & 10.0 & 05 & 144 & 5 & 3.5 \\
\hline SA04210.SU2 & $7 / 28$ & 0926 & 11.0 & B Seine & $7 / 28$ & 1100 & 14.0 & 05 & 356 & 23 & 6.5 \\
\hline SA04210.SU3 & $7 / 28$ & 1135 & 14.0 & B Seine & $7 / 28$ & 1215 & 14.0 & 06 & 85 & 10 & 11.8 \\
\hline SA04211.SU1 & $7 / 29$ & 0637 & 10.0 & B Seine & $7 / 29$ & 0930 & 12.0 & 07 & 572 & 36 & 6.3 \\
\hline \multicolumn{12}{|l|}{ Valley Creek } \\
\hline SA04215.VC1 & $8 / 02$ & 0613 & 12.5 & B Seine & $8 / 03$ & 0515 & 12.0 & 05 & 199 & 6 & 3.0 \\
\hline SA04215.VC2 & $8 / 02$ & 0817 & 12.5 & B Seine & $8 / 02$ & 1130 & 13.0 & 05 & 255 & 11 & 4.3 \\
\hline SA04215.VC3 & $8 / 02$ & 0856 & 12.5 & Shock & $8 / 03$ & 0515 & 12.0 & 05 & 199 & 7 & 3.5 \\
\hline SA04215.VC4 & $8 / 02$ & 1021 & 13.0 & Shock & $8 / 02$ & 1130 & 13.0 & 05 & 252 & 12 & 4.8 \\
\hline SA04216.VC1 & $8 / 03$ & 0647 & 12.0 & B Seine & $8 / 03$ & 1030 & 16.5 & 09 & 750 & 23 & 3.1 \\
\hline SA04217.VC1 & $8 / 04$ & 0615 & 09.0 & Shock & $8 / 05$ & 0730 & 09.0 & 18 & 200 & 20 & 10.0 \\
\hline SA04217.VC2 & $8 / 04$ & 0719 & 09.0 & B Seine & $8 / 05$ & 0730 & 09.0 & 18 & 197 & 12 & 6.1 \\
\hline SA04217.VC3 & $8 / 04$ & 1110 & 13.0 & Shock & $8 / 04$ & 1145 & 16.0 & 18 & 229 & 21 & 9.2 \\
\hline SA04217.VC4 & $8 / 04$ & 0950 & 11.5 & B Seine & $8 / 04$ & 1145 & 16.0 & 18 & 230 & 10 & 4.3 \\
\hline
\end{tabular}


Appendix Table 3a. Continued.

\begin{tabular}{|c|c|c|c|c|c|c|c|c|c|c|c|}
\hline \multirow[b]{2}{*}{ Group } & \multicolumn{3}{|c|}{ Tagging } & \multirow{2}{*}{$\begin{array}{l}\text { Capture } \\
\text { method }\end{array}$} & \multicolumn{3}{|c|}{ Release } & \multirow{2}{*}{$\begin{array}{c}\text { Stream } \\
\text { distance } \\
(\mathrm{km})\end{array}$} & \multirow[b]{2}{*}{ Released (n) } & \multicolumn{2}{|c|}{ Detected } \\
\hline & Date & Time & Temp $\left({ }^{\circ} \mathrm{C}\right)$ & & Date & Time & Temp $\left({ }^{\circ} \mathrm{C}\right)$ & & & (n) & $(\%)$ \\
\hline \multicolumn{12}{|l|}{ Loon Creek } \\
\hline SA04219.LN1 & $8 / 06$ & 0542 & 09.5 & Shock & $8 / 07$ & 0500 & 09.0 & 33 & 107 & 14 & 13.1 \\
\hline SA04219.LN2 & $8 / 06$ & 0756 & 09.0 & Shock & $8 / 06$ & 1200 & 13.5 & 34 & 782 & 74 & 9.5 \\
\hline SA04220.LN1 & $8 / 07$ & 0530 & 09.0 & Shock & $8 / 07$ & 1000 & 12.0 & 36 & 612 & 55 & 9.0 \\
\hline \multicolumn{12}{|l|}{ Camas Creek } \\
\hline SA04219.CA1 & $8 / 06$ & 0738 & 10.0 & Shock & $8 / 07$ & 0700 & 10.0 & 22 & 96 & 7 & 7.3 \\
\hline SA04219.CA2 & $8 / 06$ & 0913 & 11.0 & Shock & $8 / 06$ & 1130 & 17.0 & 23 & 632 & 53 & 8.4 \\
\hline SA04220.CA1 & $8 / 07$ & 0600 & 10.0 & Shock & $8 / 07$ & 1100 & 14.0 & 23 & 772 & 103 & 13.3 \\
\hline \multicolumn{12}{|l|}{ Herd Creek } \\
\hline SA04222.HC1 & $8 / 09$ & 0648 & 09.5 & Shock & $8 / 10$ & 0700 & 09.0 & 01 & 201 & 23 & 11.4 \\
\hline SA04222.HC2 & $8 / 09$ & 0830 & 10.0 & Shock & $8 / 09$ & 1145 & 17.5 & 02 & 1358 & 136 & 10.0 \\
\hline \multicolumn{12}{|c|}{ Big Creek (upper) } \\
\hline SA04224.BC1 & $8 / 11$ & 0623 & 08.0 & Shock & $8 / 12$ & 0445 & 08.0 & 55 & 123 & 9 & 7.3 \\
\hline SA04224.BC2 & $8 / 11$ & 0829 & 08.5 & Shock & $8 / 11$ & 1230 & 15.0 & 56 & 863 & 62 & 7.2 \\
\hline SA04225.BC1 & $8 / 12$ & 0613 & 08.0 & B Seine & $8 / 12$ & 0830 & 09.0 & 56 & 530 & 40 & 7.5 \\
\hline \multicolumn{12}{|c|}{ Big Creek (lower) } \\
\hline SA04230.LB1 & $8 / 17$ & 0619 & 15.0 & Shock & $8 / 18$ & 0330 & 14.0 & 10 & 95 & 9 & 9.5 \\
\hline SA04230.LB2 & $8 / 17$ & 0928 & 15.0 & Shock & $8 / 17$ & 1200 & 15.0 & 09 & 279 & 30 & 10.8 \\
\hline
\end{tabular}


Appendix Table 3a. Continued.

\begin{tabular}{|c|c|c|c|c|c|c|c|c|c|c|c|}
\hline \multirow[b]{2}{*}{ Group } & \multicolumn{3}{|c|}{ Tagging } & \multirow{2}{*}{$\begin{array}{l}\text { Capture } \\
\text { method }\end{array}$} & \multicolumn{3}{|c|}{ Release } & \multirow{2}{*}{$\begin{array}{c}\text { Stream } \\
\text { distance } \\
(\mathrm{km})\end{array}$} & \multirow[b]{2}{*}{ Released (n) } & \multicolumn{2}{|c|}{ Detected } \\
\hline & Date & Time & Temp $\left({ }^{\circ} \mathrm{C}\right)$ & & Date & Time & Temp $\left({ }^{\circ} \mathrm{C}\right)$ & & & (n) & $(\%)$ \\
\hline \multicolumn{12}{|c|}{ West Fork Chamberlain Creek } \\
\hline SA04230.WC1 & $8 / 17$ & 0823 & 11.5 & B Seine & $8 / 18$ & 0700 & 12.0 & 02 & 117 & 9 & 7.7 \\
\hline SA04230.WC2 & $8 / 17$ & 0911 & 12.0 & B Seine & $8 / 17$ & 1130 & 14.0 & 02 & 913 & 104 & 11.4 \\
\hline \multicolumn{12}{|c|}{ Chamberlain Creek } \\
\hline SA04231.CB1 & $8 / 18$ & 0832 & 09.0 & Shock & $8 / 18$ & 1130 & 16.0 & 25 & 298 & 14 & 4.7 \\
\hline \multicolumn{12}{|c|}{ South Fork Salmon River } \\
\hline SA04233.SF1 & $8 / 20$ & 0649 & 12.0 & Shock & $8 / 21$ & 0700 & 12.0 & 117 & 111 & 8 & 7.2 \\
\hline SA04233.SF2 & $8 / 20$ & 0821 & 12.0 & Shock & $8 / 20$ & 1140 & 16.0 & 117 & 552 & 39 & 7.1 \\
\hline SA04237.SF1 & $8 / 24$ & 0658 & 07.0 & B Seine & $8 / 24$ & 1000 & 08.0 & 123 & 08 & 0 & 0.0 \\
\hline SA04237.SF2 & $8 / 24$ & 0842 & 08.0 & Shock & $8 / 24$ & 1300 & 10.0 & 123 & 551 & 43 & 7.8 \\
\hline \multicolumn{12}{|l|}{ Secesh River } \\
\hline SA04238.SE1 & $8 / 25$ & 0647 & 09.0 & Shock & $8 / 26$ & 0530 & 08.0 & 26 & 91 & 7 & 7.7 \\
\hline SA04238.SE2 & $8 / 25$ & 0953 & 09.0 & Shock & $8 / 25$ & 1200 & 09.0 & 27 & 399 & 25 & 6.3 \\
\hline SA04239.SE1 & $8 / 26$ & 0647 & 08.0 & Shock & $8 / 26$ & 1200 & 10.0 & 27 & 584 & 39 & 6.7 \\
\hline \multicolumn{12}{|l|}{ Lake Creek } \\
\hline SA04240.LC1 & $8 / 27$ & 0710 & 07.0 & Shock & $8 / 27$ & 1230 & 10.0 & 02 & 650 & 40 & 6.2 \\
\hline
\end{tabular}


Appendix Table 3b. Universal Transverse Mercator (UTM) grid coordinates of Global Positioning System that identify sampling areas at the beginning and end of daily collections in streams for each collection crew in 2004. Hand-held Garmin GPS III-plus units were used.

\begin{tabular}{|c|c|c|c|c|c|c|}
\hline & \multirow[b]{3}{*}{ Date } & \multirow[b]{3}{*}{ Area covered } & \multicolumn{4}{|c|}{ UTM Coordinates } \\
\hline & & & \multicolumn{2}{|c|}{ Start } & \multicolumn{2}{|c|}{ End } \\
\hline & & & Northing & Easting & Northing & Easting \\
\hline \multirow[t]{5}{*}{ Bear Valley Creek } & $7 /-21-04$ & Entire Stream & 4920620 & $11 \mathrm{~T} 0633022$ & 4920920 & $11 \mathrm{~T} 0632690$ \\
\hline & $7-21-04$ & Left bank & 4920645 & $11 \mathrm{~T} 0633068$ & 4920980 & $11 \mathrm{~T} 0632752$ \\
\hline & $7-21-04$ & Right bank & 4920645 & $11 \mathrm{~T} 0633068$ & 4920980 & $11 \mathrm{TO} 632752$ \\
\hline & $7-22-04$ & Entire stream & 4919079 & 11T0630182 & 4918920 & $11 \mathrm{~T} 0629895$ \\
\hline & $7-23-04$ & Entire stream & 4918755 & $11 \mathrm{~T} 0629588$ & 4986340 & $11 \mathrm{~T} 0629623$ \\
\hline \multirow[t]{6}{*}{ Elk Creek } & $7-23-04$ & Entire stream & 4918749 & $11 \mathrm{~T} 0629570$ & 4918793 & $11 \mathrm{~T} 0629437$ \\
\hline & $7-26-04$ & Entire stream & 4916534 & $11 \mathrm{~T} 0622003$ & 4918543 & $11 \mathrm{~T} 0629226$ \\
\hline & $7-26-04$ & Left bank & 4918854 & $11 \mathrm{~T} 0629226$ & 4918840 & $11 \mathrm{~T} 0628907$ \\
\hline & $7-26-04$ & Right bank & 4918854 & $11 \mathrm{~T} 0629226$ & 4918840 & $11 \mathrm{~T} 0628907$ \\
\hline & $7-27-04$ & Right bank & 4919254 & $11 \mathrm{~T} 0628154$ & 4919406 & $11 \mathrm{~T} 0627964$ \\
\hline & $7-27-04$ & Left bank & 4919259 & $11 \mathrm{~T} 0628154$ & 4919406 & $11 \mathrm{~T} 0627964$ \\
\hline \multirow[t]{2}{*}{ Marsh Creek } & $7-28-04$ & Entire stream & 4917099 & $11 \mathrm{~T} 0646308$ & 4917113 & $11 \mathrm{~T} 0646300$ \\
\hline & $7-29-04$ & Entire stream & 4916445 & $11 \mathrm{~T} 0646887$ & 4915789 & $11 \mathrm{~T} 0647274$ \\
\hline Sulphur Creek & $7-28-04$ & Entire stream & 4233058 & $11 \mathrm{~T} 0630960$ & 4932520 & $11 \mathrm{~T} 0630367$ \\
\hline \multirow[t]{5}{*}{ Cape Horn Creek } & $7-30-04$ & Right bank & 4917424 & $11 \mathrm{~T} 0645803$ & 4916672 & $11 \mathrm{~T} 0645372$ \\
\hline & $7-30-04$ & Left bank & 4917424 & $11 \mathrm{~T} 0645803$ & 4916452 & $11 \mathrm{~T} 0645200$ \\
\hline & 7-31-04 & Right bank & 4916672 & $11 \mathrm{~T} 0645200$ & 4916487 & $11 \mathrm{~T} 0645284$ \\
\hline & $7-31-04$ & Left bank & 4916487 & $11 \mathrm{~T} 0645289$ & 4916104 & $11 \mathrm{~T} 0645119$ \\
\hline & $7-31-04$ & Right bank & 4916487 & $11 \mathrm{~T} 0645289$ & 4916104 & $11 \mathrm{~T} 0645119$ \\
\hline
\end{tabular}


Appendix Table 3b. Continued.

\begin{tabular}{|c|c|c|c|c|c|c|}
\hline & \multirow[b]{3}{*}{ Date } & \multirow[b]{3}{*}{ Area covered } & \multicolumn{4}{|c|}{ UTM Coordinates } \\
\hline & & & \multicolumn{2}{|c|}{ Start } & \multicolumn{2}{|c|}{ End } \\
\hline & & & Northing & Easting & Northing & Easting \\
\hline \multirow[t]{6}{*}{ Valley Creek } & $8-02-04$ & Entire stream & 4899452 & $11 \mathrm{~T} 0661137$ & 4899649 & $11 \mathrm{~T} 0660937$ \\
\hline & $8-02-04$ & Entire stream & 4899374 & $11 \mathrm{~T} 0661141$ & 4899614 & $11 \mathrm{~T} 0660879$ \\
\hline & $8-02-04$ & Entire stream & 4899452 & $11 \mathrm{~T} 0661137$ & 4899614 & $11 \mathrm{~T} 0660879$ \\
\hline & $8-03-04$ & Entire stream & 4901920 & $11 \mathrm{~T} 0659205$ & 4902238 & $11 \mathrm{~T} 0659331$ \\
\hline & 8-04-04 & Entire stream & 4906317 & $11 \mathrm{~T} 0657653$ & 4906524 & $11 \mathrm{~T} 0657313$ \\
\hline & 8-04-04 & Entire stream & 4906317 & 11T0657653 & 4906524 & $11 \mathrm{~T} 0657313$ \\
\hline \multirow[t]{4}{*}{ Camas Creek } & $8-06-04$ & Left bank & 4968226 & $11 \mathrm{~T} 0696518$ & 4967798 & 11T0696962 \\
\hline & $8-06-04$ & Right bank & 4968226 & $11 \mathrm{~T} 0696518$ & 4967798 & 11T0696962 \\
\hline & $8-07-04$ & Right bank & 4967784 & $11 \mathrm{~T} 0699696$ & 4967190 & $11 \mathrm{~T} 0697274$ \\
\hline & $8-07-04$ & Left bank & 4967784 & 11T0699696 & 4967190 & $11 \mathrm{~T} 0697274$ \\
\hline \multirow[t]{4}{*}{ Loon Creek } & $8-06-04$ & Left bank & 4942059 & 11T0674895 & 4940921 & $11 \mathrm{~T} 0673872$ \\
\hline & 8-06-04 & Right bank & 4942059 & $11 \mathrm{~T} 0674895$ & 4940921 & $11 \mathrm{~T} 0673872$ \\
\hline & $8-07-04$ & Left bank & 4940681 & 11T0673741 & 4940227 & $11 \mathrm{~T} 0673251$ \\
\hline & $8-07-04$ & Right bank & 4940681 & 11T0673741 & 4940227 & $11 \mathrm{~T} 0673251$ \\
\hline \multirow[t]{3}{*}{ Herd Creek } & 8-09-04 & Entire stream & 4893223 & 11T0716726 & 4891510 & $11 \mathrm{~T} 0716792$ \\
\hline & 8-09-04 & Right bank & 4892106 & $11 \mathrm{~T} 0716230$ & 4891792 & $11 \mathrm{~T} 0716584$ \\
\hline & $8-09-04$ & Left bank & 4892106 & $11 \mathrm{~T} 0716230$ & 4891792 & $11 \mathrm{~T} 0716584$ \\
\hline \multirow[t]{4}{*}{ Big Creek (upper) } & $8-11-04$ & Right bank & 4996705 & $11 \mathrm{~T} 0631585$ & 4996097 & $11 \mathrm{~T} 0631435$ \\
\hline & 8-11-04 & Left bank & 4996705 & $11 \mathrm{~T} 0631585$ & 4996097 & $11 \mathrm{~T} 0631435$ \\
\hline & $8-11-04$ & Entire stream & 4996103 & $11 \mathrm{~T} 0631365$ & 4995570 & $11 \mathrm{~T} 0631327$ \\
\hline & $8-12-04$ & Entire stream & 4995559 & $11 \mathrm{~T} 0631325$ & 4995357 & $11 \mathrm{~T} 0631329$ \\
\hline
\end{tabular}


Appendix Table 3b. Continued.

\begin{tabular}{|c|c|c|c|c|c|c|}
\hline & \multirow[b]{3}{*}{ Date } & \multirow[b]{3}{*}{ Area covered } & \multicolumn{4}{|c|}{ UTM Coordinates } \\
\hline & & & \multicolumn{2}{|c|}{ Start } & \multicolumn{2}{|c|}{ End } \\
\hline & & & Northing & Easting & Northing & Easting \\
\hline \multirow{2}{*}{ Big Creek (lower) } & $8-17-04$ & Left bank & 4996769 & $11 \mathrm{~T} 0670259$ & 4996631 & $11 \mathrm{~T} 0669466$ \\
\hline & $8-17-04$ & Right bank & 4996769 & $11 \mathrm{~T} 0670259$ & 4996631 & $11 \mathrm{~T} 0669466$ \\
\hline West Fork Chamberlain Creek & $8-17-04$ & Entire stream & 5027524 & $11 \mathrm{~T} 0641825$ & 5027868 & $11 \mathrm{~T} 064128$ \\
\hline Chamberlain Creek & $8-18-04$ & Entire stream & 5026370 & $11 \mathrm{~T} 0642256$ & 5026010 & $11 \mathrm{~T} 0641976$ \\
\hline \multirow[t]{5}{*}{ South Fork Salmon River } & $8-20-04$ & Right bank & 4943991 & $11 \mathrm{~T} 0603505$ & 4942996 & $11 \mathrm{~T} 0603447$ \\
\hline & $8-20-04$ & Left bank & 4943991 & $11 \mathrm{~T} 0603505$ & 4942966 & $11 \mathrm{~T} 0603447$ \\
\hline & $8-24-04$ & Entire stream & 4940125 & $11 \mathrm{~T} 0604741$ & 4939823 & $11 \mathrm{~T} 0604693$ \\
\hline & $8-24-04$ & Right bank & 4939823 & $11 \mathrm{~T} 0604693$ & 4939314 & $11 \mathrm{~T} 0604521$ \\
\hline & $8-24-04$ & Left bank & 4939823 & $11 \mathrm{~T} 0604693$ & 4939314 & $11 \mathrm{~T} 0604521$ \\
\hline \multirow[t]{4}{*}{ Secesh River } & $8-25-04$ & Left bank & 5005723 & $11 \mathrm{~T} 0592869$ & 5007221 & $11 \mathrm{~T} 0593501$ \\
\hline & $8-25-04$ & Right bank & 5005723 & $11 \mathrm{~T} 0592869$ & 5007221 & $11 \mathrm{~T} 0593501$ \\
\hline & $8-26-04$ & Right bank & 5007225 & $11 \mathrm{~T} 0593481$ & 5008500 & $11 \mathrm{~T} 0593520$ \\
\hline & $8-26-04$ & Left bank & 5007225 & $11 \mathrm{~T} 0593481$ & 5008500 & $11 \mathrm{~T} 0593520$ \\
\hline \multirow[t]{2}{*}{ Lake Creek } & $8-27-04$ & Left bank & 5012378 & $11 \mathrm{~T} 0586066$ & 5013419 & $11 \mathrm{~T} 0585383$ \\
\hline & $8-27-04$ & Right bank & 5012378 & 11T0586066 & 5013419 & $11 \mathrm{~T} 0585383$ \\
\hline
\end{tabular}


Appendix Table 4. Summary of observed total mortality for PIT-tagged wild Chinook salmon parr collected from Idaho streams during July and August 2004. Number rejected includes; fish too small to tag, precocious males, injured fish, fish collected for genetic evaluation, previously tagged fish, and in some cases extra collected fish.

\begin{tabular}{|c|c|c|c|c|c|c|c|c|}
\hline & \multirow[b]{2}{*}{$\begin{array}{c}\text { Total number } \\
\text { collected }\end{array}$} & \multirow[b]{2}{*}{$\begin{array}{c}\text { Total number } \\
\text { tagged }\end{array}$} & \multirow[b]{2}{*}{$\begin{array}{l}\text { Total number } \\
\text { rejected (No. } \\
\text { precocious males) }\end{array}$} & \multirow[b]{2}{*}{$\begin{array}{l}\text { Percent } \\
\text { rejected }\end{array}$} & \multicolumn{4}{|c|}{ Observed mortality } \\
\hline & & & & & $\begin{array}{l}\text { Collection } \\
\text { and } \\
\text { handling } \\
\end{array}$ & $\begin{array}{c}\text { Tagging } \\
\text { (delayed) }\end{array}$ & $\mathrm{n}$. & $\%$ \\
\hline Bear Valley Creek & 2,640 & 1,502 & $1,129(01)$ & 42.8 & 9 & 2 & 11 & 0.4 \\
\hline Elk Creek & 2,098 & 1,471 & $612(07)$ & 29.2 & 15 & 0 & 15 & 0.7 \\
\hline Marsh Creek & 2,316 & 1,503 & $809(01)$ & 34.9 & 4 & 2 & 6 & 0.3 \\
\hline Sulphur Creek & 2,086 & 1,158 & $927(11)$ & 44.4 & 1 & 1 & 2 & 0.1 \\
\hline Cape Horn Creek & 2,703 & 1,023 & $1,663(25)$ & 61.5 & 17 & 1 & 18 & 0.7 \\
\hline Valley Creek & 4,577 & 2,517 & $2,000(12)$ & 43.7 & 60 & 6 & 66 & 1.4 \\
\hline Loon Creek & 1,619 & 1,502 & $108(00)$ & 6.7 & 9 & 1 & 10 & 0.6 \\
\hline Camas Creek & 1,742 & 1,501 & $211(01)$ & 12.1 & 30 & 1 & 31 & 1.8 \\
\hline Herd Creek & 1,818 & 1,559 & $241(04)$ & 13.3 & 18 & 0 & 18 & 1.0 \\
\hline Big Creek (upper) & 1,801 & 1,516 & $277(14)$ & 15.4 & 8 & 0 & 8 & 0.4 \\
\hline Big Creek (lower) & 393 & 375 & $05(00)$ & 1.5 & 13 & 1 & 14 & 3.6 \\
\hline W.F. Chamberlain $\mathrm{Cr}$ & 1,039 & 1,033 & $06(05)$ & 0.6 & 0 & 3 & 3 & 0.3 \\
\hline Chamberlain Creek & 355 & 298 & $51(01)$ & 14.4 & 6 & 0 & 6 & 1.7 \\
\hline S.F. Salmon River & 2,489 & 1,225 & $1,248(23)$ & 50.1 & 16 & 3 & 19 & 0.8 \\
\hline Secesh River & 1,506 & 1,075 & $422(05)$ & 28.0 & 9 & 1 & 10 & 0.7 \\
\hline Lake Creek & 972 & 650 & $317(03)$ & 32.6 & 5 & 0 & 5 & 0.5 \\
\hline Totals/Averages & 30,154 & 19,908 & 10,026 & 33.3 & 220 & 22 & 242 & 0.8 \\
\hline
\end{tabular}


Appendix Table 5. Detections during 2005 of PIT-tagged smolts by date at three Snake River dams and three Columbia River dams for 1,500 wild Chinook salmon from Bear Valley Creek released 21-23 July 2004. Release sites were 629-634 km above Lower Granite Dam.

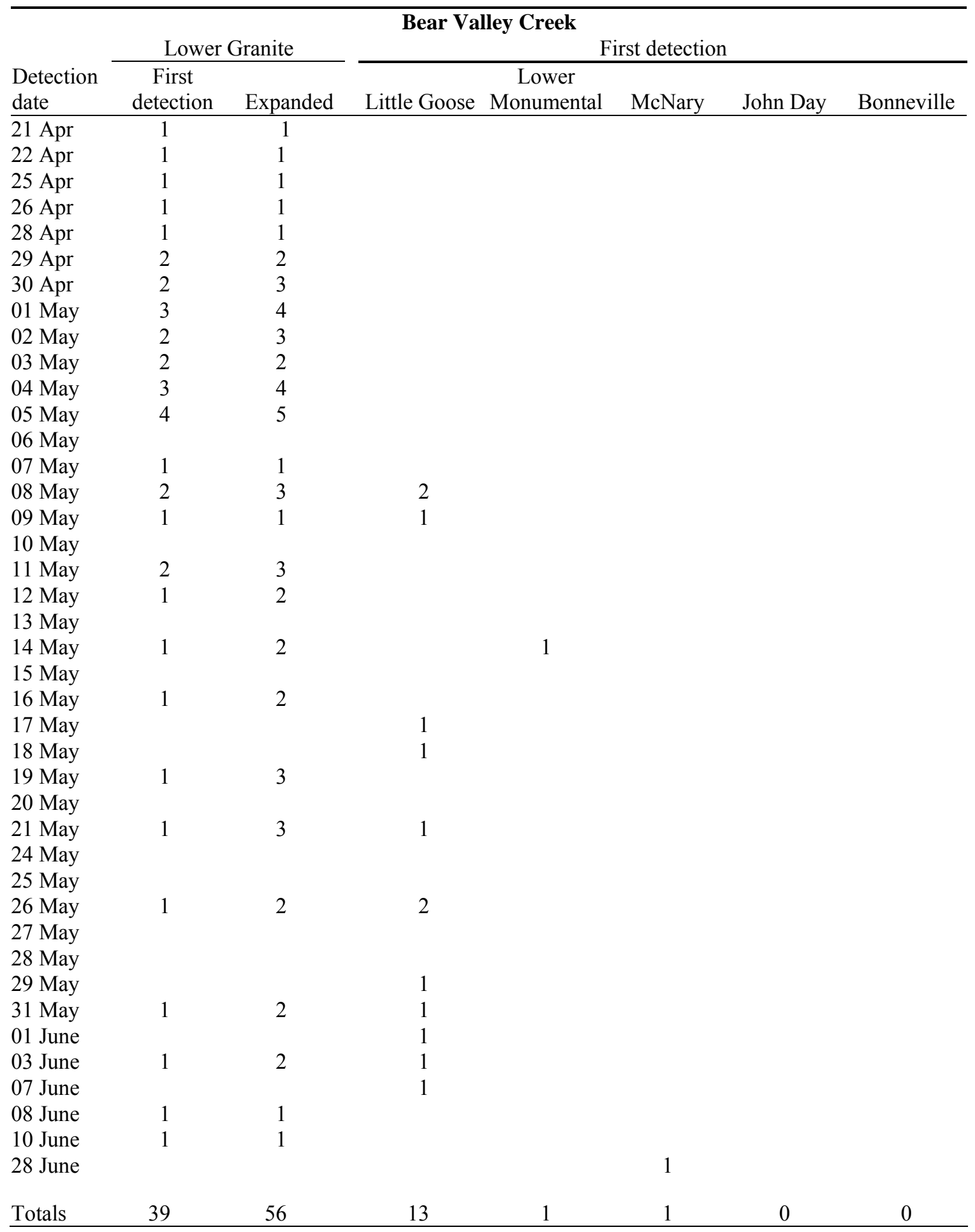


Appendix Table 6. Detections during 2005 of PIT-tagged smolts by date at three Snake River dams and three Columbia River dams for 1,471 wild Chinook salmon from Elk Creek released 23-27 July 2004. Release sites were 634-638 km above Lower Granite Dam.

\begin{tabular}{|c|c|c|c|c|c|c|c|}
\hline \multirow[b]{3}{*}{$\begin{array}{l}\text { Detection } \\
\text { date }\end{array}$} & \multicolumn{6}{|c|}{ Elk Creek } & \multirow[b]{3}{*}{ Bonneville } \\
\hline & \multicolumn{2}{|c|}{ Lower Granite } & \multicolumn{4}{|c|}{ First detection } & \\
\hline & $\begin{array}{c}\text { First } \\
\text { detection }\end{array}$ & Expanded & Little Goose & $\begin{array}{c}\text { Lower } \\
\text { Monumental }\end{array}$ & McNary & John Day & \\
\hline 18-Apr & 1 & 1 & & & & & \\
\hline \multicolumn{8}{|l|}{ 20-Apr } \\
\hline 21-Apr & 1 & 1 & & & & & \\
\hline \multicolumn{8}{|l|}{ 22-Apr } \\
\hline \multicolumn{8}{|l|}{ 23-Apr } \\
\hline \multicolumn{8}{|l|}{ 24-Apr } \\
\hline \multicolumn{8}{|l|}{ 25-Apr } \\
\hline 26-Apr & 4 & 5 & & & & & \\
\hline 27-Apr & 2 & 2 & & & & & \\
\hline \multicolumn{8}{|l|}{ 28-Apr } \\
\hline 29-Apr & 3 & 4 & & & & & \\
\hline \multicolumn{8}{|l|}{ 30-Apr } \\
\hline 01-May & 1 & 1 & & & & & \\
\hline 02-May & 2 & 3 & & & & & \\
\hline 03-May & 2 & 2 & & & & & \\
\hline 04-May & 4 & 5 & & & & & \\
\hline 05-May & 6 & 7 & & & & & \\
\hline 06-May & 3 & 4 & & & & & \\
\hline 07-May & 2 & 3 & & & & & \\
\hline 08-May & 1 & 1 & & & & & \\
\hline \multicolumn{8}{|l|}{ 09-May } \\
\hline 10-May & 1 & 1 & & & & & \\
\hline 11-May & 3 & 4 & 1 & & & & \\
\hline 12-May & 2 & 3 & & & & & \\
\hline \multicolumn{8}{|l|}{ 13-May } \\
\hline \multicolumn{8}{|l|}{ 14-May } \\
\hline 15-May & 1 & 2 & & & & & \\
\hline \multicolumn{8}{|l|}{ 16-May } \\
\hline 17-May & 1 & 2 & & & & & \\
\hline
\end{tabular}


Appendix Table 6. Continued.

\begin{tabular}{|c|c|c|c|c|c|c|c|}
\hline \multirow[b]{3}{*}{$\begin{array}{l}\text { Detection } \\
\text { date }\end{array}$} & \multicolumn{6}{|c|}{ Elk Creek (continued) } & \multirow[b]{3}{*}{ Bonneville } \\
\hline & \multicolumn{2}{|c|}{ Lower Granite } & \multicolumn{4}{|c|}{ First detection } & \\
\hline & $\begin{array}{c}\text { First } \\
\text { detection }\end{array}$ & Expanded & Little Goose I & $\begin{array}{c}\text { Lower } \\
\text { Monumental }\end{array}$ & McNary & John Day & \\
\hline 18-May & & & & & & & \\
\hline 19-May & 1 & 3 & & & & & \\
\hline 20-May & & & & & & & \\
\hline 21-May & 2 & 6 & & & & & \\
\hline 22-May & 1 & 3 & 2 & & & & \\
\hline 23-May & & & 1 & 1 & & & \\
\hline 24-May & 1 & 2 & 2 & & & & \\
\hline 25-May & 2 & 5 & 1 & & & & \\
\hline 26-May & & & 3 & & & & \\
\hline 27-May & 3 & 5 & 1 & & & & \\
\hline 29-May & 2 & 3 & 2 & & & & \\
\hline 30-May & 2 & 3 & 1 & & & & \\
\hline 31-May & & & & & & & \\
\hline 01-Jun & 1 & 2 & 1 & & & & \\
\hline 02-Jun & & & 1 & & & & \\
\hline 03-Jun & 1 & 2 & & & & & \\
\hline 05-Jun & & & & & & & \\
\hline 06-Jun & & & 1 & & & & \\
\hline 09-Jun & & & & & & & \\
\hline 10-Jun & & & & 1 & & & \\
\hline 11-Jun & & & 2 & & & & \\
\hline 12-Jun & 1 & 1 & & & & & \\
\hline 13-Jun & & & & & & & \\
\hline 14-Jun & & & & & & & \\
\hline 19-Jun & & & 1 & & & & \\
\hline 26-Jun & & & & & 1 & & \\
\hline 30-Jun & & & & & 1 & & \\
\hline Totals & 57 & 86 & 20 & 2 & 2 & 0 & 0 \\
\hline
\end{tabular}


Appendix Table 7. Detections during 2005 of PIT-tagged smolts by date at three Snake River dams and three Columbia River dams for 1,501 wild Chinook salmon from Marsh Creek released 28-29 July 2004. Release sites were 630-634 km above Lower Granite Dam.

\begin{tabular}{|c|c|c|c|c|c|c|c|}
\hline \multirow[b]{3}{*}{$\begin{array}{l}\text { Detection } \\
\text { date }\end{array}$} & \multicolumn{6}{|c|}{ Marsh Creek } & \multirow[b]{3}{*}{ Bonneville } \\
\hline & \multicolumn{2}{|c|}{ Lower Granite } & \multicolumn{4}{|c|}{ First detections } & \\
\hline & $\begin{array}{c}\text { First } \\
\text { detection }\end{array}$ & Expanded & Little Goose & $\begin{array}{c}\text { Lower } \\
\text { Monumental }\end{array}$ & McNary & John Day & \\
\hline \multicolumn{8}{|l|}{ 14-Apr } \\
\hline \multicolumn{8}{|l|}{ 15-Apr } \\
\hline \multicolumn{8}{|l|}{ 16-Apr } \\
\hline \multicolumn{8}{|l|}{ 19-Apr } \\
\hline \multicolumn{8}{|l|}{ 20-Apr } \\
\hline 22-Apr & 1 & 1 & & & & & \\
\hline 23-Apr & 1 & 1 & & & & & \\
\hline 24-Apr & 1 & 1 & & & & & \\
\hline \multicolumn{8}{|l|}{ 25-Apr } \\
\hline 26-Apr & 3 & 4 & & & & & \\
\hline 27-Apr & 3 & 4 & & & & & \\
\hline \multicolumn{8}{|l|}{ 28-Apr } \\
\hline 29-Apr & 2 & 2 & & & & & \\
\hline \multicolumn{8}{|l|}{ 30-Apr } \\
\hline 01-May & 6 & 7 & & & & & \\
\hline 02-May & 2 & 3 & & & & & \\
\hline 03-May & 5 & 6 & & & & & \\
\hline 04-May & 4 & 5 & & & & & \\
\hline 05-May & 15 & 18 & & & & & \\
\hline 06-May & 12 & 15 & & & & & \\
\hline 07-May & 5 & 6 & 1 & & & & \\
\hline 08-May & 4 & 5 & 1 & & & & \\
\hline 09-May & 3 & 4 & 2 & & & & \\
\hline 10-May & 5 & 7 & 1 & & & & \\
\hline 11-May & & & 3 & & & & \\
\hline 12-May & 3 & 5 & & & & & \\
\hline 13-May & 1 & 2 & 1 & & & & \\
\hline \multicolumn{8}{|l|}{ 14-May } \\
\hline 15-May & 1 & 2 & 1 & & & & \\
\hline
\end{tabular}


Appendix Table 7. Continued.

\begin{tabular}{|c|c|c|c|c|c|c|c|}
\hline \multirow[b]{3}{*}{$\begin{array}{l}\text { Detection } \\
\text { date }\end{array}$} & \multicolumn{6}{|c|}{ Marsh Creek (continued) } & \multirow[b]{3}{*}{ Bonneville } \\
\hline & \multicolumn{2}{|c|}{ Lower Granite } & \multicolumn{4}{|c|}{ First detections } & \\
\hline & $\begin{array}{c}\text { First } \\
\text { detection }\end{array}$ & Expanded & Little Goose & $\begin{array}{c}\text { Lower } \\
\text { Monumental }\end{array}$ & McNary & John Day & \\
\hline 17-May & & & 3 & & & & \\
\hline 18-May & 1 & 2 & 1 & & & & \\
\hline \multicolumn{8}{|l|}{ 19-May } \\
\hline 20-May & & & 1 & & & & \\
\hline 21-May & 2 & 6 & & & & & \\
\hline 23-May & & & 2 & & & & \\
\hline 24-May & & & 2 & & & & \\
\hline 25-May & 1 & 2 & 1 & & & & \\
\hline 26-May & & & 1 & & & & \\
\hline \multicolumn{8}{|l|}{ 28-May } \\
\hline 02-Jun & & & 1 & & & & \\
\hline 04-Jun & 1 & 1 & & & & & \\
\hline \multicolumn{8}{|l|}{ 05-Jun } \\
\hline 'Totals & 82 & 109 & 22 & 0 & 0 & 0 & 0 \\
\hline
\end{tabular}


Appendix Table 8. Detections during 2005 of PIT-tagged smolts by date at three Snake River dams and three Columbia River dams for 1,022 wild Chinook salmon from Cape Horn Creek released 30-31 July 2004. Release sites were 629-632 km above Lower Granite Dam.

\begin{tabular}{|c|c|c|c|c|c|c|c|}
\hline & & & Cape H & orn Creek & & & \\
\hline & Lowe & Granite & & & st detectio & & \\
\hline $\begin{array}{l}\text { Detection } \\
\text { date }\end{array}$ & $\begin{array}{c}\text { First } \\
\text { detection }\end{array}$ & Expanded & Little Goose & $\begin{array}{c}\text { Lower } \\
\text { Monumental }\end{array}$ & McNary & John Day & Bonneville \\
\hline 11-Apr & 1 & 1 & & & & & \\
\hline 14-Apr & & & & & & & \\
\hline 15-Apr & & & & & & & \\
\hline 17-Apr & & & & & & & \\
\hline 18-Apr & & & & & & & \\
\hline 20-Apr & 1 & 1 & & & & & \\
\hline 24-Apr & 1 & 1 & & & & & \\
\hline 25-Apr & 1 & 1 & & & & & \\
\hline 26-Apr & 1 & 1 & & & & & \\
\hline 27-Apr & & & & & & & \\
\hline 28-Apr & 1 & 1 & & & & & \\
\hline 29-Apr & 2 & 2 & & & & & \\
\hline 30-Apr & & & & & & & \\
\hline 01-May & 1 & 1 & & & & & \\
\hline 02-May & & & 1 & & & & \\
\hline 03-May & 2 & 2 & & & & & \\
\hline 04-May & 3 & 4 & & & & & \\
\hline 05-May & 13 & 15 & & & & & \\
\hline 06-May & 2 & 2 & & & & & \\
\hline 07-May & 3 & 4 & & & & & \\
\hline 08-May & 1 & 1 & & & & & \\
\hline 09-May & 2 & 3 & & & & & \\
\hline 10-May & 3 & 4 & & & 1 & & \\
\hline 11-May & 3 & 4 & 1 & & & & \\
\hline 12-May & 2 & 3 & & & & & \\
\hline 13-May & 1 & 2 & & & & & \\
\hline 14-May & & & 1 & & & & \\
\hline 15-May & 1 & 2 & & & & & \\
\hline 19-May & 1 & 3 & & & & & \\
\hline 20-May & & & & & & & \\
\hline 23-May & 2 & 5 & 2 & & & & \\
\hline 24-May & 2 & 5 & & & & & \\
\hline 25-May & 1 & 2 & & & & & \\
\hline 26-May & & & 2 & & & & \\
\hline 28-May & 1 & 2 & & & & & \\
\hline 29-May & 2 & 3 & & & & & \\
\hline 03-Jul & & & & & 1 & & \\
\hline Totals & 54 & 75 & 7 & 0 & 2 & 0 & 0 \\
\hline
\end{tabular}


Appendix Table 9. Detections during 2005 of PIT-tagged smolts by date at three Snake River dams and three Columbia River dams for 1,157 wild Chinook salmon from Sulphur Creek released 28-29 July 2004. Fish were released 604-606 km above Lower Granite Dam.

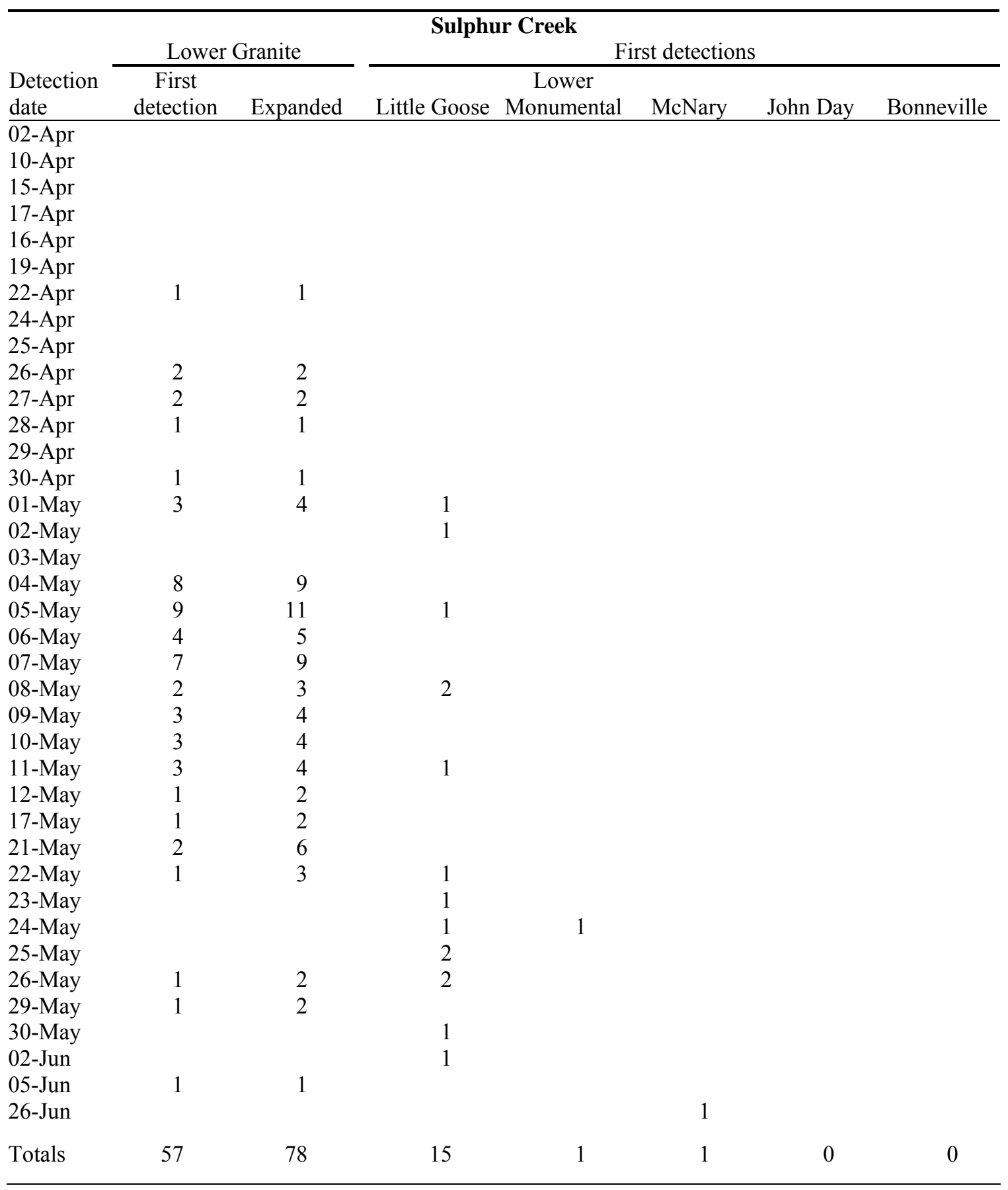


Appendix Table 10. Detections during 2005 of PIT-tagged smolts by date at three Snake River dams and three Columbia River dams for 2,511 wild Chinook salmon from Valley Creek released 02-05 August 2004. Release sites were 743-757 km above Lower Granite Dam.

\begin{tabular}{|c|c|c|c|c|c|c|c|}
\hline \multirow[b]{3}{*}{$\begin{array}{l}\text { Detection } \\
\text { date }\end{array}$} & \multicolumn{6}{|c|}{ Valley Creek } & \multirow[b]{3}{*}{ Bonneville } \\
\hline & \multicolumn{2}{|c|}{ Lower Granite } & \multicolumn{4}{|c|}{ First detections } & \\
\hline & $\begin{array}{c}\text { First } \\
\text { detection }\end{array}$ & Expanded & Little Goose & $\begin{array}{c}\text { Lower } \\
\text { Monumental }\end{array}$ & McNary & John Day & \\
\hline 04-Apr & & & & & & & \\
\hline 14-Apr & & & & & & & \\
\hline 15-Apr & & & & & & & \\
\hline 19-Apr & & & & & & & \\
\hline 21-Apr & & & & & & & \\
\hline 23-Apr & 1 & 1 & & & & & \\
\hline 24-Apr & & & & & & & \\
\hline 25-Apr & & & & & & & \\
\hline 26-Apr & 2 & 2 & & & & & \\
\hline 27-Apr & 10 & 12 & & & & & \\
\hline 28-Apr & 2 & 2 & & & & & \\
\hline 29-Apr & 3 & 4 & & & & & \\
\hline 30-Apr & 2 & 3 & & & & & \\
\hline 01-May & 2 & 2 & & & & & \\
\hline 02-May & 1 & 1 & & & & & \\
\hline 03-May & 2 & 2 & & & & & \\
\hline 04-May & 1 & 1 & & & & & \\
\hline 05-May & 6 & 7 & & & & & \\
\hline 06-May & 5 & 6 & & & & & \\
\hline 07-May & 4 & 5 & 1 & & & & \\
\hline 08-May & 5 & 6 & & & & & \\
\hline 09-May & 6 & 9 & 1 & & & & \\
\hline 10-May & 2 & 3 & & & & & \\
\hline 11-May & 1 & 1 & 1 & & & & \\
\hline 12-May & 2 & 3 & & & & & \\
\hline 13-May & 1 & 2 & & & & & \\
\hline 14-May & & & 2 & & & & \\
\hline 15-May & & & 1 & & & & \\
\hline 16-May & & & & & & & \\
\hline 17-May & & & & & & & \\
\hline 18-May & 1 & 2 & & 1 & & & \\
\hline 19-May & 1 & 3 & & & & & \\
\hline 20-May & 1 & 3 & & & & & \\
\hline 21-May & 1 & 3 & 1 & & & & \\
\hline 22-May & 2 & 6 & 3 & & & & \\
\hline 23-May & 1 & 2 & 2 & & & & \\
\hline
\end{tabular}


Appendix Table 10. Continued.

\begin{tabular}{|c|c|c|c|c|c|c|c|}
\hline \multirow[b]{3}{*}{$\begin{array}{l}\text { Detection } \\
\text { date }\end{array}$} & \multicolumn{6}{|c|}{ Valley Creek (continued) } & \multirow[b]{3}{*}{ Bonneville } \\
\hline & \multicolumn{2}{|c|}{ Lower Granite } & \multicolumn{4}{|c|}{ First detections } & \\
\hline & $\begin{array}{c}\text { First } \\
\text { detection }\end{array}$ & Expanded & Little Goose & $\begin{array}{c}\text { Lower } \\
\text { Monumental }\end{array}$ & McNary & John Day & \\
\hline 24-May & 2 & 5 & & & & & \\
\hline 25-May & 1 & 2 & 4 & & & & \\
\hline 26-May & 1 & 2 & & & & & \\
\hline 27-May & 1 & 2 & & & & & \\
\hline 28-May & 1 & 2 & 1 & & & & \\
\hline 29-May & 2 & 3 & 1 & & & & \\
\hline 30-May & 1 & 1 & 1 & & & 1 & \\
\hline 31-May & & & 1 & & & & \\
\hline 01-Jun & 2 & 3 & 1 & & & & \\
\hline 02-Jun & 3 & 5 & 2 & & & & \\
\hline 03-Jun & 3 & 5 & & & & & \\
\hline 04-Jun & 1 & 1 & & & & & \\
\hline 05-Jun & 2 & 3 & & & & & \\
\hline 06-Jun & 2 & 3 & & & & & \\
\hline 08-Jun & 2 & 3 & & & & & \\
\hline 09-Jun & 1 & 1 & & & & & \\
\hline 10-Jun & 2 & 3 & & & & & \\
\hline 12-Jun & 1 & 1 & & & & & \\
\hline 18-Jun & 1 & 1 & & & & & \\
\hline 19-Jun & & & 1 & & & & \\
\hline 20-Jun & 1 & 7 & & & & & \\
\hline 28-Jun & & & & & 1 & & \\
\hline Totals & 95 & 147 & 24 & 1 & 1 & 1 & 0 \\
\hline
\end{tabular}


Appendix Table 11. Detections during 2005 of PIT-tagged smolts by date at three Snake River dams and three Columbia River dams for 1,501 wild Chinook salmon from Loon Creek released 06-07 August 2004. Release sites were 555-559 km above Lower Granite Dam.

\begin{tabular}{|c|c|c|c|c|c|c|c|}
\hline \multirow[b]{3}{*}{$\begin{array}{l}\text { Detection } \\
\text { date }\end{array}$} & \multicolumn{6}{|c|}{ Loon Creek } & \multirow[b]{3}{*}{ Bonneville } \\
\hline & \multicolumn{2}{|c|}{ Lower Granite } & \multicolumn{4}{|c|}{$\begin{array}{r}\text { First detections } \\
\text { I }\end{array}$} & \\
\hline & $\begin{array}{c}\text { First } \\
\text { detection }\end{array}$ & Expanded & Little Goose & $\begin{array}{c}\text { Lower } \\
\text { Monumental }\end{array}$ & McNary & John Day & \\
\hline 20-Apr & 1 & 1 & & & & & \\
\hline 21-Apr & 1 & 1 & & & & & \\
\hline 22-Apr & 1 & 1 & & & & & \\
\hline 25-Apr & & & & & & & \\
\hline 26-Apr & & & & & & & \\
\hline 27-Apr & 3 & 4 & & & & & \\
\hline 28-Apr & & & & & & & \\
\hline 29-Apr & 3 & 4 & & & & & \\
\hline 30-Apr & & & & & & & \\
\hline 01-May & 2 & 2 & & & & & \\
\hline 02-May & 1 & 1 & & & & & \\
\hline 03-May & & & 1 & & & & \\
\hline 04-May & 3 & 4 & & & & & \\
\hline 05-May & 16 & 19 & & & & & \\
\hline 06-May & 13 & 16 & 1 & & & & \\
\hline 07-May & 5 & 6 & 1 & & & & \\
\hline 08-May & 9 & 12 & 1 & & & & \\
\hline 09-May & 3 & 4 & 2 & & & & \\
\hline 10-May & 6 & 9 & 1 & & & & \\
\hline 11-May & 7 & 10 & 2 & & & & \\
\hline 12-May & 7 & 11 & & & & & \\
\hline 13-May & 4 & 7 & 1 & & & & \\
\hline 14-May & 1 & 2 & 1 & & & & \\
\hline 15-May & & & 1 & & & & \\
\hline 16-May & 2 & 5 & 1 & & & & \\
\hline 17-May & 1 & 2 & & & & & \\
\hline 18-May & & & 1 & & & & \\
\hline 19-May & & & & & & & \\
\hline 20-May & & & & & & & \\
\hline 21-May & 3 & 9 & 2 & & & & \\
\hline 22-May & & & 2 & & & & \\
\hline 23-May & 2 & 5 & 8 & & & & \\
\hline 24-May & 1 & 2 & 5 & & & & \\
\hline 25-May & 2 & 5 & 2 & & & & \\
\hline 26-May & & & & & & & \\
\hline 28-May & & & 1 & & & & \\
\hline 29-May & & & 2 & & & & \\
\hline 30-May & 2 & 3 & 2 & & & & \\
\hline 31-May & & & 2 & & & & \\
\hline 01-Jun & 1 & 2 & 1 & & & & \\
\hline 02-Jun & 1 & 2 & & & & & \\
\hline 03-Jun & 1 & 2 & & & & & \\
\hline Totals & 102 & 151 & 41 & 0 & 0 & 0 & 0 \\
\hline
\end{tabular}


Appendix Table 12. Detections during 2005 of PIT-tagged smolts by date at three Snake River dams and three Columbia River dams for 1,500 wild Chinook salmon from Camas Creek released 06-07 August 2004. Release sites were 526-528 km above Lower Granite Dam.

\begin{tabular}{|c|c|c|c|c|c|c|c|}
\hline \multirow[b]{3}{*}{$\begin{array}{l}\text { Detection } \\
\text { date }\end{array}$} & \multicolumn{6}{|c|}{ Camas Creek } & \multirow[b]{3}{*}{ Bonneville } \\
\hline & \multicolumn{2}{|c|}{ Lower Granite } & \multicolumn{4}{|c|}{ First detections } & \\
\hline & $\begin{array}{c}\text { First } \\
\text { detection }\end{array}$ & Expanded & Little Goose & $\begin{array}{c}\text { Lower } \\
\text { Monumental }\end{array}$ & McNary & John Day & \\
\hline 12-Apr & 1 & 1 & & & & & \\
\hline \multicolumn{8}{|l|}{ 17-Apr } \\
\hline \multicolumn{8}{|l|}{ 19-Apr } \\
\hline \multicolumn{8}{|l|}{ 20-Apr } \\
\hline \multicolumn{8}{|l|}{ 21-Apr } \\
\hline \multicolumn{8}{|l|}{ 22-Apr } \\
\hline 23-Apr & 3 & 4 & & & & & \\
\hline 24-Apr & 1 & 1 & & & & & \\
\hline 25-Apr & 1 & 1 & & & & & \\
\hline 26-Apr & 3 & 4 & & & & & \\
\hline 27-Apr & 2 & 2 & & & & & \\
\hline 28-Apr & 2 & 2 & & & & & \\
\hline 29-Apr & 2 & 2 & & & & & \\
\hline 30-Apr & 1 & 1 & & & & & \\
\hline 01-May & 2 & 2 & & & & & \\
\hline 02-May & 2 & 3 & & & & & \\
\hline 03-May & 3 & 4 & & & & & \\
\hline 04-May & 9 & 11 & & & & & \\
\hline 05-May & 13 & 15 & 1 & & & & \\
\hline 06-May & 24 & 29 & 1 & & & & \\
\hline 07-May & 6 & 8 & & & & & \\
\hline 08-May & 1 & 1 & 2 & & & & \\
\hline 09-May & 1 & 1 & 2 & & & & \\
\hline 10-May & 5 & 7 & 2 & 1 & & & \\
\hline 11-May & 5 & 7 & 1 & & & & \\
\hline 12-May & 2 & 3 & & & & & \\
\hline 13-May & 5 & 9 & & & & & \\
\hline \multicolumn{8}{|l|}{ 14-May } \\
\hline 15-May & 1 & 2 & & & & & \\
\hline 16-May & & & 1 & & & & \\
\hline \multicolumn{8}{|l|}{ 17-May } \\
\hline 18-May & 1 & 2 & 1 & & & & \\
\hline 19-May & 3 & 8 & & & & & \\
\hline
\end{tabular}


Appendix Table 12. Continued.

\section{Camas Creek (continued)}

\begin{tabular}{|c|c|c|c|c|c|c|c|}
\hline \multirow[b]{2}{*}{$\begin{array}{l}\text { Detection } \\
\text { date }\end{array}$} & \multicolumn{2}{|c|}{ Lower Granite } & \multicolumn{5}{|c|}{ First detections } \\
\hline & $\begin{array}{c}\text { First } \\
\text { detection }\end{array}$ & Expanded & Little Goose & $\begin{array}{c}\text { Lower } \\
\text { Monumental }\end{array}$ & McNary & John Day & Bonneville \\
\hline 20-May & 1 & 3 & & & & & \\
\hline 21-May & 3 & 9 & 2 & & & & \\
\hline 22-May & & & & & & & \\
\hline 23-May & 1 & 2 & 7 & & 1 & & \\
\hline 24-May & 1 & 2 & & & & & \\
\hline 25-May & 2 & 5 & 2 & & & & \\
\hline 26-May & 1 & 2 & 3 & & & & \\
\hline 27-May & & & & & & & \\
\hline 28-May & 2 & 3 & 3 & & & & \\
\hline 29-May & 3 & 5 & 2 & & & & \\
\hline 30-May & 1 & 1 & 2 & & & & \\
\hline 31-May & 1 & 2 & & & & & \\
\hline 01-Jun & & & 2 & & & & \\
\hline 02-Jun & & & 1 & & & & \\
\hline 04-Jun & 1 & 1 & & & & & \\
\hline 05-Jun & 1 & 1 & & & & & \\
\hline 06-Jun & 2 & 3 & & & & & \\
\hline 07-Jun & 1 & 1 & 1 & & & & \\
\hline 08-Jun & & & 1 & & & & \\
\hline 10-Jun & 1 & 1 & & & & & \\
\hline 14-Jun & & & 1 & & & & \\
\hline 19-Jun & 1 & 1 & & & & & \\
\hline 28-Jun & & & & & 1 & & \\
\hline Totals & 122 & 172 & 38 & 1 & 2 & 0 & 0 \\
\hline
\end{tabular}


Appendix Table 13. Detections during 2005 of PIT-tagged smolts by date at three Snake River dams and three Columbia River dams for 1,559 wild Chinook salmon from Herd Creek released 09-10 August 2004. Fish were released 699-701 km above Lower Granite Dam.

\begin{tabular}{|c|c|c|c|c|c|c|c|}
\hline \multirow[b]{3}{*}{$\begin{array}{l}\text { Detection } \\
\text { date }\end{array}$} & \multicolumn{6}{|c|}{ Herd Creek } & \multirow[b]{3}{*}{ Bonneville } \\
\hline & \multicolumn{2}{|c|}{ Lower Granite } & \multicolumn{4}{|c|}{ First detections } & \\
\hline & $\begin{array}{c}\text { First } \\
\text { detection }\end{array}$ & Expanded & Little Goose & $\begin{array}{c}\text { Lower } \\
\text { Monumental }\end{array}$ & McNary & John Day & \\
\hline $20-\mathrm{Apr}$ & 2 & 2 & & & & & \\
\hline 21-Apr & & & & & & & \\
\hline 22-Apr & 1 & 1 & & & & & \\
\hline 23-Apr & & & & & & & \\
\hline 24-Apr & & & & & & & \\
\hline 25-Apr & 2 & 2 & & & & & \\
\hline 26-Apr & 5 & 6 & & & & & \\
\hline $27-A p r$ & 7 & 8 & & & & & \\
\hline 28-Apr & 4 & 5 & & & & & \\
\hline 29-Apr & 2 & 2 & 1 & & & & \\
\hline 30-Apr & 1 & 1 & & & & & \\
\hline 01-May & 7 & 9 & & & & & \\
\hline 02-May & 2 & 3 & 1 & & & & \\
\hline 03-May & 1 & 1 & & & & & \\
\hline 04-May & 4 & 5 & & & & & \\
\hline 05-May & 9 & 11 & & & & & \\
\hline 06-May & 14 & 17 & 1 & & & & \\
\hline 07-May & 12 & 15 & 1 & & & & \\
\hline 08-May & 16 & 21 & 2 & & & & \\
\hline 09-May & 6 & 9 & 1 & & & & \\
\hline 10-May & 2 & 3 & 4 & & & & \\
\hline 11-May & 5 & 7 & 3 & & & & \\
\hline 12-May & 3 & 5 & & & & & \\
\hline 13-May & 3 & 5 & & 1 & & & \\
\hline 14-May & 2 & 4 & & & & & \\
\hline 15-May & & & 2 & & 1 & & \\
\hline 16-May & 1 & 2 & 2 & 1 & & & \\
\hline 17-May & & & & & & & \\
\hline 18-May & 3 & 7 & & & 1 & & \\
\hline 19-May & 2 & 5 & 1 & & & & \\
\hline 20-May & & & 1 & & & & \\
\hline 21-May & & & 1 & & & & \\
\hline 22-May & 1 & 3 & 1 & 1 & & & \\
\hline 23-May & 1 & 2 & & & & & \\
\hline 24-May & 1 & 2 & 1 & 1 & & & \\
\hline 25-May & & & 2 & & & & \\
\hline 28-May & & & 1 & & & & \\
\hline 01-Jun & 4 & 7 & 1 & & & & \\
\hline 04-Jun & & & 1 & & & & \\
\hline 06-Jun & 1 & 2 & & & & & \\
\hline 13-Jun & 1 & 1 & & & & & \\
\hline Totals & 125 & 173 & 28 & 4 & 2 & 0 & 0 \\
\hline
\end{tabular}


Appendix Table 14. Detections during 2005 of PIT-tagged smolts by date at three Snake River dams and three Columbia River dams for 1,516 wild Chinook salmon from Big Creek (upper) released 11-12 August 2004.

Release sites were 530-532 km above Lower Granite Dam.

\begin{tabular}{|c|c|c|c|c|c|c|c|}
\hline & & & Herd & Creek & & & \\
\hline & Lower & Granite & & & st detectio & & \\
\hline $\begin{array}{l}\text { Detection } \\
\text { date }\end{array}$ & $\begin{array}{c}\text { First } \\
\text { detection }\end{array}$ & Expanded & Little Goose & $\begin{array}{c}\text { Lower } \\
\text { Monumental }\end{array}$ & McNary & John Day & Bonneville \\
\hline 20-Apr & 1 & 1 & & & & & \\
\hline 22-Apr & 1 & 1 & & & & & \\
\hline 23-Apr & 1 & 1 & & & & & \\
\hline 26-Apr & 1 & 1 & & & & & \\
\hline 27-Apr & 8 & 10 & & & & & \\
\hline 28-Apr & 4 & 5 & & & & & \\
\hline 29-Apr & 1 & 1 & & & & & \\
\hline 30-Apr & 1 & 1 & & & & & \\
\hline 01-May & 1 & 1 & & & & & \\
\hline 02-May & 3 & 4 & & & & & \\
\hline 03-May & 2 & 2 & & & & & \\
\hline 04-May & 5 & 6 & & & & & \\
\hline 05-May & 11 & 13 & & & & & \\
\hline 06-Мay & 10 & 12 & & & & & \\
\hline 07-May & 5 & 6 & & & & & \\
\hline 08-May & 7 & 9 & 2 & & & & \\
\hline 09-May & 5 & 7 & & & & & \\
\hline 10-May & & & 1 & & & & \\
\hline 11-May & 1 & 1 & 2 & & & & \\
\hline 12-May & 1 & 2 & & & & & \\
\hline 13-May & 1 & 2 & & & 1 & & \\
\hline 14-Мay & & & & & & & \\
\hline 15-May & 1 & 2 & & & & & \\
\hline 16-Мау & & & & 1 & & & \\
\hline 17-May & & & 1 & & & & \\
\hline 18-May & 1 & 2 & & & & & \\
\hline 20-May & 2 & 6 & 1 & & & & \\
\hline 21-May & 1 & 3 & 1 & & & & \\
\hline 22-May & 1 & 3 & & & 1 & & \\
\hline 23-May & 3 & 7 & 3 & & & & \\
\hline 24-May & 1 & 2 & & & & & \\
\hline 25-May & 1 & 2 & & 1 & & & \\
\hline 26-May & & & 1 & 1 & & & \\
\hline 27-May & 3 & 5 & & & & & \\
\hline 28-May & 2 & 3 & 2 & & & & \\
\hline 29-Мау & 1 & 2 & & & & & \\
\hline 31-May & 1 & 2 & & & & & \\
\hline 01-Jun & & & & & & & \\
\hline 02-Jun & 1 & 2 & & & & & \\
\hline 03-Jun & 1 & 2 & & & & & \\
\hline 07-Jun & 1 & 1 & & & & & \\
\hline 30-Jun & & & & & 1 & & \\
\hline Totals & 91 & 130 & 14 & 3 & 3 & 0 & 0 \\
\hline
\end{tabular}


Appendix Table 15. Detections during 2005 of PIT-tagged smolts by date at three Snake River dams and three Columbia River dams for 374 wild Chinook salmon from Big Creek (lower) released 17-18 August 2004. Release sites were 487-488 km above Lower Granite Dam.

\begin{tabular}{|c|c|c|c|c|c|c|c|}
\hline \multirow{3}{*}{$\begin{array}{l} \\
\text { Detection } \\
\text { date }\end{array}$} & \multicolumn{6}{|c|}{ Big Creek (lower) } & \multirow[b]{3}{*}{ Bonneville } \\
\hline & \multicolumn{2}{|c|}{ Lower Granite } & \multicolumn{4}{|c|}{ First detections } & \\
\hline & $\begin{array}{c}\text { First } \\
\text { detection }\end{array}$ & Expanded & Little Goose & $\begin{array}{c}\text { Lower } \\
\text { Monumental }\end{array}$ & McNary & John Day & \\
\hline \multicolumn{8}{|l|}{ 06-Apr } \\
\hline \multicolumn{8}{|l|}{ 07-Apr } \\
\hline \multicolumn{8}{|l|}{ 14-Apr } \\
\hline \multicolumn{8}{|l|}{ 15-Apr } \\
\hline \multicolumn{8}{|l|}{ 16-Apr } \\
\hline \multicolumn{8}{|l|}{ 17-Apr } \\
\hline \multicolumn{8}{|l|}{ 18-Apr } \\
\hline \multicolumn{8}{|l|}{ 19-Apr } \\
\hline 20-Apr & 1 & 1 & & & & & \\
\hline 21-Apr & 1 & 1 & & & & & \\
\hline 22-Apr & 2 & 2 & & & & & \\
\hline 23-Apr & 1 & 1 & & & & & \\
\hline \multicolumn{8}{|l|}{ 24-Apr } \\
\hline 25-Apr & 1 & 1 & & & & & \\
\hline 26-Apr & 4 & 5 & & & & & \\
\hline 27-Apr & 2 & 2 & & & & & \\
\hline 28-Apr & 1 & 1 & & & & & \\
\hline 29-Apr & 1 & 1 & & & & & \\
\hline \multicolumn{8}{|l|}{ 30-Apr } \\
\hline 01-May & 2 & 2 & & & & & \\
\hline 02-May & 2 & 3 & 1 & & & & \\
\hline 03-May & 1 & 1 & & & & & \\
\hline \multicolumn{8}{|l|}{ 04-May } \\
\hline 05-May & 6 & 7 & & & & & \\
\hline 06-May & 4 & 5 & 1 & & & & \\
\hline 07-May & 1 & 1 & & & & & \\
\hline 08-May & 1 & 1 & 1 & & & & \\
\hline 09-May & 2 & 3 & & & & & \\
\hline 10-May & 1 & 1 & & & & & \\
\hline \multicolumn{8}{|l|}{ 11-May } \\
\hline 12-May & & & & 1 & & & \\
\hline 14-May & & & 1 & & & & \\
\hline \multicolumn{8}{|l|}{ 15-May } \\
\hline \multicolumn{8}{|l|}{ 28-May } \\
\hline Totals & 34 & 39 & 4 & 1 & 0 & 0 & 0 \\
\hline
\end{tabular}


Appendix Table 16. Detections during 2005 of PIT-tagged smolts by date at three Snake River dams and three Columbia River dams for 1,328 wild Chinook salmon from West Fork Chamberlain Creek* released 17-18 August 2004. Release sites were 437-438 km above Lower Granite Dam.

\begin{tabular}{|c|c|c|c|c|c|c|c|}
\hline \multirow[b]{3}{*}{$\begin{array}{l}\text { Detection } \\
\text { date }\end{array}$} & \multicolumn{6}{|c|}{ West Fork Chamberlain Creek* } & \multirow[b]{3}{*}{ Bonneville } \\
\hline & \multicolumn{2}{|c|}{ Lower Granite } & \multicolumn{4}{|c|}{$\begin{array}{ll}\text { First detections } \\
\end{array}$} & \\
\hline & $\begin{array}{c}\text { First } \\
\text { detection }\end{array}$ & Expanded & Little Goose & $\begin{array}{c}\text { Lower } \\
\text { Monumental }\end{array}$ & McNary & John Day & \\
\hline$\overline{15-\mathrm{Apr}}$ & & & & & & & \\
\hline 17-Apr & & & & & & & \\
\hline 18-Apr & & & & & & & \\
\hline 19-Apr & & & & & & & \\
\hline 20-Apr & 1 & 1 & & & & & \\
\hline 21-Apr & & & & & & & \\
\hline 22-Apr & 2 & 2 & & & & & \\
\hline 23-Apr & 2 & 2 & & & & & \\
\hline 24-Apr & 3 & 4 & & & & & \\
\hline 25-Apr & & & & & & & \\
\hline 26-Apr & 8 & 10 & & & & & \\
\hline 27-Apr & 18 & 22 & 1 & & & & \\
\hline 28-Apr & 7 & 9 & & & & & \\
\hline 29-Apr & 4 & 5 & 2 & & & & \\
\hline 30-Apr & 3 & 4 & 1 & & & & \\
\hline 01-May & 4 & 5 & & & & & \\
\hline 02-May & 1 & 1 & & & & & \\
\hline 03-May & 6 & 7 & 2 & & & & \\
\hline 04-May & 8 & 9 & & & & & \\
\hline 05-May & 8 & 9 & 2 & & & & \\
\hline 06-May & 9 & 11 & 1 & & & & \\
\hline 07-May & 4 & 5 & 2 & & & & \\
\hline 08-May & 3 & 4 & 3 & & & & \\
\hline 09-May & 3 & 4 & 3 & & & & \\
\hline 10-May & 2 & 3 & 2 & & & & \\
\hline 11-May & 2 & 3 & & & & & \\
\hline 13-May & 1 & 2 & & & & & \\
\hline 15-May & & & & & & & \\
\hline 16-Мау & & & & & & & \\
\hline 17-May & & & & & & & \\
\hline 19-May & 1 & 3 & & & & & \\
\hline 22-May & 1 & 3 & & & & & \\
\hline 23-May & & & & & & & \\
\hline 25-May & & & & & & & \\
\hline 26-May & 1 & 2 & & & & & \\
\hline 29-May & 1 & 2 & & & & & \\
\hline 30-May & 2 & 3 & & & & & \\
\hline 31-May & & & 1 & & & & \\
\hline 01-Jun & & & 1 & & & & \\
\hline 04-Jun & & & 1 & & & & \\
\hline Totals & 105 & 135 & 22 & 0 & 0 & 0 & 0 \\
\hline
\end{tabular}

* Includes fish from Chamberlain Creek 
Appendix Table 17. Detections during 2005 of PIT-tagged smolts by date at three Snake River dams and three Columbia River dams for 1,222 wild Chinook salmon from South Fork Salmon River released 20-24 August 2004. Release sites were 467-473 km above Lower Granite Dam.

\begin{tabular}{|c|c|c|c|c|c|c|c|}
\hline \multirow{3}{*}{$\begin{array}{l}\begin{array}{l}\text { Detection } \\
\text { date }\end{array} \\
\end{array}$} & \multicolumn{6}{|c|}{ South Fork Salmon River } & \multirow[b]{3}{*}{ Bonneville } \\
\hline & \multicolumn{2}{|c|}{ Lower Granite } & \multicolumn{4}{|c|}{ First detections } & \\
\hline & $\begin{array}{c}\text { First } \\
\text { detection }\end{array}$ & Expanded & Little Goose & $\begin{array}{c}\text { Lower } \\
\text { Monumental } \\
\end{array}$ & McNary & John Day & \\
\hline 16-Apr & & & & & & & \\
\hline 17-Apr & & & & & & & \\
\hline 18-Apr & & & & & & & \\
\hline 20-Apr & & & & & & & \\
\hline 21-Apr & & & & & & & \\
\hline 22-Apr & 2 & 2 & & & & & \\
\hline 24-Apr & & & & & & & \\
\hline 25-Apr & & & & & & & \\
\hline 26-Apr & 3 & 4 & & & & & \\
\hline 27-Apr & 2 & 2 & 1 & & & & \\
\hline 28-Apr & 1 & 1 & & & & & \\
\hline 29-Apr & 2 & 2 & & & & & \\
\hline 01-May & 1 & 1 & & & & & \\
\hline 03-May & & & & & & & \\
\hline 04-May & 4 & 5 & & & & & \\
\hline 05-May & 4 & 5 & 3 & & & & \\
\hline 06-May & 7 & 8 & & & & & \\
\hline 07-May & 3 & 4 & & & & & \\
\hline 08-May & 5 & 6 & & & & & \\
\hline 09-May & 1 & 1 & 1 & & & & \\
\hline 10-May & & & 1 & & & & \\
\hline 11-May & & & 1 & & & & \\
\hline 12-May & 2 & 3 & 1 & & & & \\
\hline 13-May & & & 1 & & & & \\
\hline 14-May & 1 & 2 & & & & & \\
\hline 15-May & 1 & 2 & 1 & & & & \\
\hline 16-May & & & & & & 1 & \\
\hline 18-May & & & & & & & \\
\hline 19-May & & & & & & & \\
\hline 20-May & 1 & 3 & 1 & & & & \\
\hline 21-May & & & & & & & \\
\hline 22-May & 1 & 3 & & & & & \\
\hline 23-May & & & 1 & 1 & & & \\
\hline 24-May & & & 1 & & & & \\
\hline 25-May & 5 & 11 & 4 & & & & \\
\hline 26-May & 1 & 2 & 1 & & & & \\
\hline
\end{tabular}


Appendix Table 17. Continued.

\begin{tabular}{|c|c|c|c|c|c|c|c|}
\hline \multirow[b]{3}{*}{$\begin{array}{l}\text { Detection } \\
\text { date }\end{array}$} & \multicolumn{6}{|c|}{ South Fork Salmon River (continued) } & \multirow[b]{3}{*}{ Bonneville } \\
\hline & \multicolumn{2}{|c|}{ Lower Granite } & \multicolumn{4}{|c|}{ First detections } & \\
\hline & $\begin{array}{c}\text { First } \\
\text { detection }\end{array}$ & Expanded & Little Goose & $\begin{array}{c}\text { Lower } \\
\text { Monumental }\end{array}$ & McNary & John Day & \\
\hline 27-May & 3 & 5 & & & & & \\
\hline 28-May & 1 & 2 & 2 & & & & \\
\hline 29 May & 1 & 2 & 1 & 1 & & & \\
\hline 30-May & 1 & 1 & & & & & \\
\hline 31-May & & & & & 1 & & \\
\hline 01-Jun & & & 3 & & & & \\
\hline 02-Jun & 1 & 2 & & & & & \\
\hline 03-Jun & & & & 1 & & & \\
\hline 04-Jun & 1 & 1 & & & & & \\
\hline 06-Jun & 1 & 2 & & & & & \\
\hline 08-Jun & 1 & 1 & & & & & \\
\hline 09-Jun & & & & & & & \\
\hline 11-Jun & & & & & & & \\
\hline 12-Jun & & & & 1 & & & \\
\hline 13-Jun & & & & & & & \\
\hline 17-Jun & & & & & & & \\
\hline 19-Jun & 1 & 1 & & & & & \\
\hline 30-Jun & & & & & 1 & & \\
\hline 01-Jul & & & & & 1 & & \\
\hline Totals & 58 & 84 & 24 & 4 & 3 & 1 & 0 \\
\hline
\end{tabular}


Appendix Table 18. Detections during 2005 of PIT-tagged smolts by date at three Snake River dams and three Columbia River dams for 1,074 wild Chinook salmon from Secesh River released 25-26 August 2004. Release sites were 429-431 km above Lower Granite Dam.

\begin{tabular}{|c|c|c|c|c|c|c|c|}
\hline \multirow[b]{3}{*}{$\begin{array}{l}\text { Detection } \\
\text { date }\end{array}$} & \multicolumn{6}{|c|}{ Secesh River } & \multirow[b]{3}{*}{ Bonneville } \\
\hline & \multicolumn{2}{|c|}{ Lower Granite } & \multicolumn{4}{|c|}{ First detections } & \\
\hline & $\begin{array}{c}\text { First } \\
\text { detection }\end{array}$ & Expanded & Little Goose & $\begin{array}{c}\text { Lower } \\
\text { Monumental }\end{array}$ & McNary & John Day & \\
\hline$\overline{04-A p r}$ & 1 & 1 & & & & & \\
\hline 08-Apr & & & & & & & \\
\hline 15-Apr & 1 & 1 & & & & & \\
\hline 18-Apr & & & & & & & \\
\hline 19-Apr & 1 & 1 & & & & & \\
\hline 20-Apr & 2 & 2 & & & & & \\
\hline $23-\mathrm{Apr}$ & 2 & 2 & & & & & \\
\hline 24-Apr & 2 & 2 & & & & & \\
\hline 25-Apr & & & & & & & \\
\hline 26-Apr & 5 & 6 & & & & & \\
\hline 27-Apr & 4 & 5 & & & & & \\
\hline 28-Apr & 2 & 2 & & & & & \\
\hline $29-A p r$ & 1 & 1 & 1 & & & & \\
\hline 30-Apr & 3 & 4 & & & & & \\
\hline 01-May & 4 & 5 & & & & & \\
\hline 02-May & 2 & 3 & & & & & \\
\hline 03-May & 3 & 4 & 2 & & & & \\
\hline 04-May & & & & & & & \\
\hline 05-May & 4 & 5 & & & & & \\
\hline 06-May & 5 & 6 & & & & & \\
\hline 07-May & 3 & 4 & & & & & \\
\hline 08-May & 1 & 1 & & & & & \\
\hline 10-May & 1 & 1 & & & & & \\
\hline 11-May & & & 1 & & & & \\
\hline 12-May & 1 & 2 & 1 & & & & \\
\hline 13-May & 2 & 3 & & & & & \\
\hline 14-May & 1 & 2 & & & & & \\
\hline 15-May & & & & & & & \\
\hline 16-May & & & & 1 & & & \\
\hline 21-May & & & & & & & \\
\hline 22-May & & & & & & & \\
\hline 24-May & & & & & & & \\
\hline 26-May & 2 & 4 & 2 & & & & \\
\hline 28-May & & & & & & & \\
\hline 29-May & 1 & 2 & & & & & \\
\hline 31-May & 2 & 3 & & & & & \\
\hline 01-Jun & & & 1 & & & & \\
\hline 04-Jun & & & 1 & & & & \\
\hline 08-Jun & & & & & & & \\
\hline 10-Jun & & & 1 & & & & \\
\hline 11-Jun & & & 1 & & & & \\
\hline 19-Jun & 1 & 1 & & & & & \\
\hline Totals & 58 & 74 & 12 & 1 & 0 & 0 & 0 \\
\hline
\end{tabular}


Appendix Table 19. Detections during 2005 of PIT-tagged smolts by date at three Snake River dams and three Columbia River dams for 650 wild Chinook salmon from Lake Creek released 27 August 2004. Release sites were 451-452 km above Lower Granite Dam.

\begin{tabular}{|c|c|c|c|c|c|c|c|}
\hline \multirow[b]{3}{*}{$\begin{array}{l}\text { Detection } \\
\text { date }\end{array}$} & \multicolumn{6}{|c|}{ Lake Creek } & \multirow[b]{3}{*}{ Bonneville } \\
\hline & \multicolumn{2}{|c|}{ Lower Granite } & \multicolumn{4}{|c|}{ First detections } & \\
\hline & $\begin{array}{c}\text { First } \\
\text { detection }\end{array}$ & Expanded & Little Goose & $\begin{array}{c}\text { Lower } \\
\text { Monumental }\end{array}$ & McNary & John Day & \\
\hline \multicolumn{8}{|l|}{ 09-Apr } \\
\hline \multicolumn{8}{|l|}{ 14-Apr } \\
\hline \multicolumn{8}{|l|}{ 15-Apr } \\
\hline \multicolumn{8}{|l|}{ 16-Apr } \\
\hline 19-Apr & 1 & 1 & & & & & \\
\hline 20-Apr & 5 & 6 & & & & & \\
\hline \multicolumn{8}{|l|}{ 21-Apr } \\
\hline 22-Apr & 1 & 1 & & & & & \\
\hline 24-Apr & 1 & 1 & & & & & \\
\hline \multicolumn{8}{|l|}{ 25-Apr } \\
\hline 26-Apr & 2 & 2 & & & & & \\
\hline 27-Apr & 7 & 8 & & & & & \\
\hline 28-Apr & 2 & 2 & & & & & \\
\hline 29-Apr & 2 & 2 & 1 & & & & \\
\hline \multicolumn{8}{|l|}{ 30-Apr } \\
\hline 01-May & 1 & 1 & & & & & \\
\hline 02-May & & & 1 & & & & \\
\hline 03-May & 1 & 1 & 1 & & & & \\
\hline \multicolumn{8}{|l|}{ 04-May } \\
\hline 06-May & 2 & 2 & & & & & \\
\hline 07-May & 1 & 1 & & & & & \\
\hline 08-May & & & 1 & & & & \\
\hline 09-May & 1 & 1 & 1 & & & & \\
\hline \multicolumn{8}{|l|}{ 10-May } \\
\hline 11-May & 1 & 1 & 1 & & & & \\
\hline \multicolumn{8}{|l|}{ 12-May } \\
\hline \multicolumn{8}{|l|}{ 14-May } \\
\hline \multicolumn{8}{|l|}{ 16-May } \\
\hline \multicolumn{8}{|l|}{ 19-May } \\
\hline 20-May & 1 & 3 & & & & & \\
\hline \multicolumn{8}{|l|}{ 22-May } \\
\hline \multicolumn{8}{|l|}{ 23-May } \\
\hline 26-May & 1 & 2 & & & & & \\
\hline \multicolumn{8}{|l|}{ 28-May } \\
\hline 29-May & 1 & 2 & & & & & \\
\hline \multicolumn{8}{|l|}{ 04-Jun } \\
\hline 05-Jun & & & & & & & \\
\hline 06-Jun & & & & & & & \\
\hline 08-Jun & 1 & 1 & & & & & \\
\hline 11-Jun & & & & & & & \\
\hline 19-Jun & 1 & 1 & & & & & \\
\hline 30-Jun & & & & & 1 & & \\
\hline Totals & 33 & 39 & 6 & 0 & 1 & 0 & 0 \\
\hline
\end{tabular}


Appendix Table 20. Daily and expanded detections of PIT-tagged wild spring/summer Chinook salmon smolts from Idaho and Oregon at Lower Granite Dam during 2005, with associated river flows (kcfs), spill ( $\mathrm{kcfs}$ ), and water temperatures $\left({ }^{\circ} \mathrm{C}\right)$ at the dam.

\begin{tabular}{|c|c|c|c|c|c|c|c|}
\hline \multirow[b]{2}{*}{ Date } & \multirow[b]{2}{*}{$\begin{array}{c}\text { Average } \\
\text { flow (kcfs) }\end{array}$} & \multirow[b]{2}{*}{$\begin{array}{l}\text { Average } \\
\text { spill (kcfs) }\end{array}$} & \multirow[b]{2}{*}{$\begin{array}{l}\text { Scroll-case } \\
\text { water } \\
\text { temperature }\end{array}$} & \multicolumn{2}{|c|}{ Idaho only } & \multicolumn{2}{|c|}{ Idaho and Oregon } \\
\hline & & & & $\begin{array}{l}\text { Numbers } \\
\text { detected }\end{array}$ & $\begin{array}{l}\text { Expanded } \\
\text { numbers } \\
\text { detected }\end{array}$ & $\begin{array}{l}\text { Numbers } \\
\text { detected }\end{array}$ & $\begin{array}{c}\text { Expanded } \\
\text { numbers } \\
\text { detected }\end{array}$ \\
\hline $01 \mathrm{Apr}$ & 38.9 & 0.0 & 7.8 & 0 & 0 & 0 & 0 \\
\hline $02 \mathrm{Apr}$ & 38.3 & 0.0 & 7.2 & 0 & 0 & 0 & 0 \\
\hline $03 \mathrm{Apr}$ & 36.1 & 0.0 & 7.2 & 0 & 0 & 0 & 0 \\
\hline 04 Apr & 33.9 & 0.0 & 7.2 & 1 & 1 & 1 & 1 \\
\hline $05 \mathrm{Apr}$ & 41.1 & 0.0 & 7.2 & 0 & 0 & 2 & 3 \\
\hline $06 \mathrm{Apr}$ & 42.9 & 0.0 & 7.2 & 0 & 0 & 0 & 0 \\
\hline $07 \mathrm{Apr}$ & 37.7 & 0.0 & 7.2 & 0 & 0 & 2 & 2 \\
\hline $08 \mathrm{Apr}$ & 36.3 & 0.0 & 7.2 & 0 & 0 & 1 & 1 \\
\hline 09 Apr & 42.8 & 0.0 & 8.3 & 0 & 0 & 0 & 0 \\
\hline $10 \mathrm{Apr}$ & 40.4 & 0.0 & 8.7 & 0 & 0 & 0 & 0 \\
\hline $11 \mathrm{Apr}$ & 47.0 & 0.0 & 10.0 & 1 & 1 & 3 & 4 \\
\hline $12 \mathrm{Apr}$ & 37.1 & 0.0 & 10.0 & 1 & 1 & 4 & 5 \\
\hline $13 \mathrm{Apr}$ & 38.0 & 0.0 & 10.0 & 0 & 0 & 2 & 2 \\
\hline $14 \mathrm{Apr}$ & 39.1 & 0.0 & 10.0 & 0 & 0 & 4 & 5 \\
\hline $15 \mathrm{Apr}$ & 39.5 & 0.0 & 10.0 & 1 & 1 & 6 & 7 \\
\hline $16 \mathrm{Apr}$ & 35.7 & 0.0 & 10.0 & 0 & 0 & 3 & 4 \\
\hline 17 Apr & 37.7 & 0.0 & 9.4 & 0 & 0 & 0 & 0 \\
\hline $18 \mathrm{Apr}$ & 45.0 & 0.0 & 9.4 & 1 & 1 & 9 & 11 \\
\hline 19 Apr & 43.3 & 0.0 & 9.4 & 2 & 2 & 11 & 14 \\
\hline $20 \mathrm{Apr}$ & 43.5 & 0.0 & 9.4 & 14 & 17 & 24 & 30 \\
\hline $21 \mathrm{Apr}$ & 41.3 & 0.0 & 9.4 & 5 & 6 & 10 & 12 \\
\hline $22 \mathrm{Apr}$ & 39.6 & 0.0 & 10.0 & 13 & 16 & 15 & 19 \\
\hline $23 \mathrm{Apr}$ & 39.8 & 0.0 & 10.0 & 11 & 13 & 14 & 17 \\
\hline $24 \mathrm{Apr}$ & 41.9 & 0.0 & 10.0 & 9 & 11 & 12 & 14 \\
\hline $25 \mathrm{Apr}$ & 45.9 & 0.0 & 10.6 & 6 & 7 & 11 & 13 \\
\hline $26 \mathrm{Apr}$ & 47.9 & 0.0 & 11.1 & 44 & 53 & 54 & 65 \\
\hline $27 \mathrm{Apr}$ & 52.7 & 0.0 & 11.1 & 70 & 85 & 81 & 98 \\
\hline $28 \mathrm{Apr}$ & 55.1 & 0.0 & 11.1 & 28 & 34 & 37 & 45 \\
\hline $29 \mathrm{Apr}$ & 54.9 & 0.0 & 11.1 & 30 & 37 & 44 & 54 \\
\hline $30 \mathrm{Apr}$ & 54.1 & 2.7 & 11.1 & 14 & 18 & 20 & 25 \\
\hline 01 May & 51.6 & 0.0 & 11.7 & 40 & 50 & 47 & 58 \\
\hline 02 May & 47.7 & 3.8 & 11.1 & 20 & 26 & 27 & 34 \\
\hline 03 May & 46.1 & 0.0 & 11.1 & 30 & 35 & 32 & 38 \\
\hline 04 May & 49.4 & 0.0 & 11.1 & 56 & 66 & 63 & 74 \\
\hline 05 May & 60.4 & 0.0 & 11.7 & 124 & 147 & 132 & 156 \\
\hline 06 May & 67.0 & 0.0 & 11.7 & 114 & 138 & 125 & 151 \\
\hline 07 May & 79.4 & 3.1 & 11.7 & 62 & 79 & 73 & 93 \\
\hline 08 May & 82.4 & 0.0 & 11.7 & 58 & 75 & 72 & 93 \\
\hline 09 May & 77.6 & 6.2 & 11.7 & 37 & 55 & 54 & 80 \\
\hline 10 May & 91.3 & 6.2 & 11.7 & 31 & 44 & 43 & 61 \\
\hline
\end{tabular}


Appendix Table 20. Continued.

\begin{tabular}{|c|c|c|c|c|c|c|c|}
\hline \multirow[b]{2}{*}{ Date } & \multirow[b]{2}{*}{$\begin{array}{c}\text { Average } \\
\text { flow }(\mathrm{kcfs})\end{array}$} & \multirow[b]{2}{*}{$\begin{array}{l}\text { Average } \\
\text { spill (kcfs) }\end{array}$} & \multirow[b]{2}{*}{$\begin{array}{l}\text { Scroll-case } \\
\text { water } \\
\text { temperature }\end{array}$} & \multicolumn{2}{|c|}{ Idaho only } & \multicolumn{2}{|c|}{ Idaho and Oregon } \\
\hline & & & & $\begin{array}{c}\text { Numbers } \\
\text { detected }\end{array}$ & $\begin{array}{l}\text { Expanded } \\
\text { numbers } \\
\text { detected }\end{array}$ & $\begin{array}{c}\text { Numbers } \\
\text { detected }\end{array}$ & $\begin{array}{c}\text { Expanded } \\
\text { numbers } \\
\text { detected }\end{array}$ \\
\hline 11 May & 98.9 & 13.5 & 11.1 & 33 & 46 & 41 & 57 \\
\hline 12 May & 88.7 & 4.0 & 11.1 & 27 & 41 & 29 & 44 \\
\hline 13 May & 85.1 & 1.5 & 11.7 & 19 & 33 & 23 & 40 \\
\hline 14 May & 84.6 & 0.0 & 11.7 & 6 & 12 & 8 & 16 \\
\hline 15 May & 83.9 & 0.0 & 11.7 & 6 & 12 & 6 & 12 \\
\hline 16 May & 91.7 & 7.6 & 11.7 & 4 & 9 & 5 & 11 \\
\hline 17 May & 124.1 & 37.9 & 11.7 & 3 & 7 & 5 & 11 \\
\hline 18 May & 121.8 & 35.8 & 11.7 & 7 & 15 & 8 & 17 \\
\hline 19 May & 118.7 & 33.6 & 11.7 & 10 & 27 & 13 & 35 \\
\hline 20 May & 135.3 & 48.6 & 11.1 & 6 & 17 & 9 & 26 \\
\hline 21 May & 138.0 & 51.6 & 11.7 & 15 & 45 & 18 & 53 \\
\hline 22 May & 125.6 & 39.9 & 12.2 & 8 & 23 & 10 & 29 \\
\hline 23 May & 122.8 & 37.1 & 12.2 & 10 & 25 & 12 & 30 \\
\hline 24 May & 116.2 & 30.3 & 12.2 & 9 & 22 & 9 & 22 \\
\hline 25 May & 100.9 & 15.8 & 11.7 & 15 & 34 & 15 & 34 \\
\hline 26 May & 98.8 & 14.0 & 12.2 & 9 & 19 & 10 & 21 \\
\hline 27 May & 89.2 & 4.7 & 13.3 & 10 & 18 & 11 & 20 \\
\hline 28 May & 87.4 & 2.7 & 13.3 & 7 & 11 & 8 & 13 \\
\hline 29 May & 84.3 & 0.0 & 13.3 & 19 & 31 & 21 & 34 \\
\hline 30 May & 81.4 & 0.0 & 13.3 & 9 & 13 & 10 & 15 \\
\hline 31 May & 79.0 & 5.0 & 13.3 & 5 & 8 & 7 & 12 \\
\hline 01 Jun & 88.7 & 11.2 & 13.3 & 4 & 6 & 6 & 10 \\
\hline 02 Jun & 89.9 & 8.0 & 13.3 & 6 & 9 & 7 & 11 \\
\hline 03 Jun & 83.8 & 1.6 & 13.9 & 7 & 11 & 10 & 15 \\
\hline 04 Jun & 76.5 & 0.0 & 13.9 & 4 & 6 & 6 & 9 \\
\hline 05 Jun & 74.3 & 0.0 & 13.9 & 4 & 6 & 4 & 6 \\
\hline 06 Jun & 74.0 & 11.0 & 13.9 & 6 & 9 & 6 & 9 \\
\hline 07 Jun & 74.1 & 16.8 & 13.3 & 2 & 3 & 2 & 3 \\
\hline 08 Jun & 62.7 & 0.0 & 13.3 & 5 & 7 & 6 & 9 \\
\hline 09 Jun & 59.9 & 2.9 & 14.4 & 1 & 1 & 1 & 1 \\
\hline 10 Jun & 54.1 & 0.0 & 14.4 & 4 & 5 & 4 & 5 \\
\hline 11 Jun & 51.6 & 0.0 & 13.9 & 0 & 0 & 1 & 1 \\
\hline 12 Jun & 50.3 & 0.0 & ---- & 2 & 3 & 2 & 3 \\
\hline 13 Jun & 50.6 & 0.0 & 13.9 & 1 & 1 & 1 & 1 \\
\hline 14 Jun & 50.4 & 0.0 & 13.9 & 0 & 0 & 0 & 0 \\
\hline 15 Jun & 48.3 & 0.0 & 14.4 & 0 & 0 & 0 & 0 \\
\hline 16 Jun & 44.8 & 0.0 & 14.4 & 0 & 0 & 0 & 0 \\
\hline 17 Jun & 46.3 & 0.0 & 14.4 & 0 & 0 & 0 & 0 \\
\hline 18 Jun & 50.7 & 0.0 & 14.4 & 1 & 1 & 2 & 3 \\
\hline 19 Jun & 52.6 & 0.1 & 15.0 & 4 & 5 & 4 & 5 \\
\hline 20 Jun & 55.6 & 39.2 & 15.0 & 1 & 7 & 1 & 7 \\
\hline 21 Jun & 51.5 & 23.4 & 15.0 & 0 & 0 & 0 & 0 \\
\hline 22 Jun & 51.0 & 18.1 & 14.4 & 0 & 0 & 0 & 0 \\
\hline 23 Jun & 51.5 & 33.9 & 15.0 & 0 & 0 & 0 & 0 \\
\hline
\end{tabular}


Appendix Table 21. Daily first-time detections of PIT-tagged wild spring/summer Chinook salmon smolts from Idaho at Little Goose Dam during 2005, with associated river flows (kcfs), spill (kcfs), and water temperatures $\left({ }^{\circ} \mathrm{C}\right)$ at the dam.

\begin{tabular}{|c|c|c|c|c|}
\hline Date & $\begin{array}{l}\text { Average } \\
\text { flow(kcfs) }\end{array}$ & $\begin{array}{c}\text { Average } \\
\text { Spill(kcfs) }\end{array}$ & $\begin{array}{l}\text { Scroll-case water } \\
\text { temperature }\left({ }^{\circ} \mathrm{C}\right)\end{array}$ & $\begin{array}{r}\text { Numbers } \\
\text { detected }\end{array}$ \\
\hline $22 \mathrm{Apr}$ & 39.4 & 0.0 & 10.0 & 1 \\
\hline 27 Apr & 53.0 & 0.0 & 11.7 & 2 \\
\hline 29 Apr & 55.8 & 0.0 & 11.7 & 5 \\
\hline $30 \mathrm{Apr}$ & 53.4 & 0.0 & 11.7 & 1 \\
\hline 01 May & 53.6 & 0.0 & 11.7 & 1 \\
\hline 02 May & 47.8 & 0.0 & 12.2 & 5 \\
\hline 03 May & 48.1 & 0.0 & 12.5 & 6 \\
\hline 05 May & 60.5 & 0.0 & 12.8 & 7 \\
\hline 06 May & 65.5 & 0.0 & 12.8 & 5 \\
\hline 07 May & 79.7 & 0.0 & 12.2 & 6 \\
\hline 08 May & 82.5 & 0.0 & 12.2 & 17 \\
\hline 09 May & 78.5 & 0.0 & 12.2 & 14 \\
\hline 10 May & 89.6 & 0.0 & 12.2 & 12 \\
\hline 11 May & 97.9 & 0.0 & 11.7 & 18 \\
\hline 12 May & 88.5 & 0.0 & 11.7 & 2 \\
\hline 13 May & 85.0 & 0.0 & 12.2 & 3 \\
\hline 14 May & 84.8 & 0.0 & 12.2 & 5 \\
\hline 15 May & 84.0 & 0.0 & 12.2 & 6 \\
\hline 16 May & 89.2 & 0.0 & 11.7 & 4 \\
\hline 17 May & 121.8 & 13.5 & 11.7 & 5 \\
\hline 18 May & 115.8 & 6.7 & 12.2 & 4 \\
\hline 19 May & 112.6 & 5.5 & 12.2 & 1 \\
\hline 20 May & 129.1 & 18.6 & 12.2 & 4 \\
\hline 21 May & 134.1 & 24.1 & 12.2 & 8 \\
\hline 22 May & 120.2 & 23.1 & 12.2 & 9 \\
\hline 23 May & 118.4 & 9.5 & 12.2 & 27 \\
\hline
\end{tabular}


Appendix Table 21. Continued.

\begin{tabular}{lcccc}
\hline Date & $\begin{array}{c}\text { Average } \\
\text { flow(kcfs) }\end{array}$ & $\begin{array}{c}\text { Average } \\
\text { Spill(kcfs) }\end{array}$ & $\begin{array}{c}\text { Scroll-case water } \\
\text { temperature }\left({ }^{\circ} \mathrm{C}\right)\end{array}$ & $\begin{array}{c}\text { Numbers } \\
\text { detected }\end{array}$ \\
\hline 24 May & 111.9 & 2.0 & 12.2 & 12 \\
25 May & 98.2 & 0.0 & 12.2 & 18 \\
26 May & 97.1 & 0.0 & 12.2 & 17 \\
27 May & 88.4 & 0.0 & 12.2 & 1 \\
28 May & 86.0 & 0.0 & 12.2 & 10 \\
29 May & 85.8 & 0.0 & 12.8 & 9 \\
30 May & 81.5 & 0.0 & 12.8 & 7 \\
31 May & 77.7 & 0.0 & 12.8 & 5 \\
01 Jun & 86.0 & 1.0 & 13.3 & 12 \\
02 Jun & 89.1 & 0.0 & 13.3 & 6 \\
03 Jun & 84.7 & 0.0 & 13.3 & 1 \\
04 Jun & 75.2 & 0.0 & 13.9 & 3 \\
06 Jun & 72.8 & 0.0 & 14.4 & 1 \\
07 Jun & 70.6 & 0.0 & 13.9 & 2 \\
08 Jun & 62.0 & 0.0 & 14.4 & 1 \\
10 Jun & 54.1 & 0.0 & 14.4 & 1 \\
11 Jun & 50.4 & 0.0 & 13.9 & 3 \\
14 Jun & 51.5 & 0.0 & 14.5 & 1 \\
19 Jun & 53.7 & 0.0 & 15.6 & 2 \\
\hline
\end{tabular}


Appendix Table 22. Daily first-time detections of PIT-tagged wild spring/summer Chinook salmon smolts from Idaho at Lower Monumental Dam during 2005, with associated river flows (kcfs), spill (kcfs), and water temperatures $\left({ }^{\circ} \mathrm{C}\right)$ at the dam.

\begin{tabular}{lcccc}
\hline Date & $\begin{array}{c}\text { Average } \\
\text { flow }(\mathrm{kcfs})\end{array}$ & $\begin{array}{c}\text { Average } \\
\text { Spill }(\mathrm{kcfs})\end{array}$ & $\begin{array}{c}\text { Scroll-case water } \\
\text { temperature }\left({ }^{\circ} \mathrm{C}\right)\end{array}$ & $\begin{array}{c}\text { Numbers } \\
\text { detected }\end{array}$ \\
\hline 10 May & 92.4 & 5.3 & 12.2 & 1 \\
12 May & 93.9 & 3.2 & 12.2 & 1 \\
13 May & 87.5 & 5.0 & 12.2 & 1 \\
14 May & 87.1 & 15.3 & 12.2 & 1 \\
16 May & 91.6 & 2.1 & 12.2 & 3 \\
18 May & 119.0 & 24.0 & 12.2 & 1 \\
22 May & 123.8 & 32.1 & 12.2 & 1 \\
23 May & 119.6 & 24.3 & 12.2 & 2 \\
24 May & 116.6 & 21.6 & 12.8 & 1 \\
25 May & 102.6 & 9.3 & 13.3 & 1 \\
26 May & 101.3 & 13.8 & 13.3 & 1 \\
29 May & 89.5 & 1.5 & 13.3 & 1 \\
03 Jun & 89.7 & 2.7 & 14.4 & 1 \\
10 Jun & 56.5 & 0.0 & 15.0 & 15.0 \\
12 Jun & 51.0 & 0.0 & & 1 \\
\hline
\end{tabular}


Appendix Table 23. Daily first-time detections of PIT-tagged wild spring/summer Chinook salmon smolts from Idaho at McNary Dam during 2005, with associated river flows (kcfs), spill ( $\mathrm{kcfs}$ ), and water temperatures at the dam. Two first-time detections occurred at John Day Dam (16 and 30 May); no first-time detections occurred at Bonneville Dam, Ice Harbor Dam, or the surface-trawl detector at the mouth of the river.

\begin{tabular}{lcccc}
\hline Date & $\begin{array}{c}\text { Average } \\
\text { flow(kcfs) }\end{array}$ & $\begin{array}{c}\text { Average } \\
\text { Spill(kcfs) }\end{array}$ & $\begin{array}{c}\text { Water } \\
\text { temperature }\left({ }^{\circ} \mathrm{C}\right)\end{array}$ & $\begin{array}{c}\text { Numbers } \\
\text { detected }\end{array}$ \\
\hline 10 May & 242.5 & 85.1 & 12.5 & 1 \\
13 May & 247.5 & 105.2 & 12.6 & 1 \\
15 May & 242.5 & 78.7 & 13.2 & 1 \\
18 May & 277.5 & 118.2 & 12.6 & 1 \\
22 May & 263.8 & 173.9 & 12.7 & 1 \\
23 May & 251.3 & 105.0 & 12.9 & 1 \\
31 May & 193.0 & 65.3 & 14.7 & 2 \\
26 Jun & 200.5 & 24.6 & 17.2 & 3 \\
28 Jun & 188.9 & 20.5 & 17.2 & 4 \\
30 Jun & 215.5 & 41.8 & 17.3 & 1 \\
01 Jul & 230.1 & 175.3 & $---{ }^{-1}$ & 1 \\
03 Jul & 184.9 & 130.1 & 18.1 & 1 \\
\hline
\end{tabular}


Appendix Table 24. Monthly environmental data collected from Marsh Creek (RKm 179.5 from the mouth of the Middle Fork Salmon River) from August 2004 through July 2005.

\begin{tabular}{|c|c|c|c|c|c|c|c|c|c|c|c|c|}
\hline & Aug & Sep & Oct & Nov & Dec & Jan & Feb & Mar & Apr & May & Jun & Jul \\
\hline \multicolumn{13}{|c|}{ Temperature $\left({ }^{\circ} \mathrm{C}\right)$} \\
\hline Min & 6.1 & 3.5 & 0.0 & -0.1 & 0.0 & 0.0 & --- & --- & 0.0 & 0.7 & 3.2 & 6.7 \\
\hline Max & 15.9 & 15.8 & 11.9 & 5.6 & 3.7 & 0.0 & --- & --- & 10.5 & 12.8 & 15.9 & 15.9 \\
\hline Mean & 11.1 & 8.5 & 5.0 & 1.6 & 0.4 & 0.0 & --- & --- & 3.7 & 5.9 & 8.5 & 11.4 \\
\hline \multicolumn{13}{|c|}{ Dissolved Oxygen (ppm) } \\
\hline Min & 8.9 & 0.9 & --- & --- & 13.9 & 13.6 & --- & --- & 4.8 & 1.2 & --- & --- \\
\hline Max & 13.2 & 12.7 & --- & --- & 14.2 & 14.2 & --- & --- & 12.3 & 11.4 & --- & --- \\
\hline Mean & 11.0 & 6.7 & --- & --- & 14.1 & 14.0 & --- & --- & 10.8 & 10.0 & --- & --- \\
\hline \multicolumn{13}{|c|}{ Specific Conductance $(\mu \mathrm{S} / \mathrm{cm})$} \\
\hline Min & 58.0 & 57.0 & 56.0 & 47.0 & 58.0 & 61.0 & --- & --- & 20.0 & 20.0 & 23.0 & 34.0 \\
\hline Max & 65.0 & 65.0 & 65.0 & 66.0 & 68.0 & 66.0 & --- & --- & 57.0 & 42.0 & 35.0 & 42.0 \\
\hline Mean & 61.2 & 61.6 & 60.2 & 60.4 & 63.0 & 63.2 & --- & --- & 48.7 & 30.7 & 30.0 & 38.7 \\
\hline \multicolumn{13}{|c|}{ Turbidity (ntu) } \\
\hline Min & 0.0 & 0.0 & 0.0 & 0.0 & --- & --- & --- & --- & 0.0 & 2.3 & 7.2 & 16.0 \\
\hline Max & 47.1 & 3.9 & 26.9 & 35.3 & --- & --- & --- & --- & 46.9 & 39.6 & 49.5 & 50.0 \\
\hline Mean & 10.4 & 0.9 & 3.3 & 1.7 & --- & --- & --- & --- & 5.6 & 7.1 & 18.5 & 36.7 \\
\hline \multicolumn{13}{|c|}{ Depth (feet) } \\
\hline Min & 0.7 & 0.7 & 0.4 & 0.2 & 0.7 & 0.5 & --- & --- & 0.4 & 1.2 & 1.4 & 1.1 \\
\hline Max & 1.4 & 1.3 & 1.3 & 1.5 & 2.4 & 2.7 & --- & --- & 1.9 & 2.9 & 2.4 & 1.6 \\
\hline Mean & 1.1 & 1.0 & 0.9 & 1.0 & 1.5 & 1.5 & --- & --- & 1.0 & 1.9 & 1.8 & 1.3 \\
\hline \multicolumn{13}{|c|}{$\mathrm{pH}$} \\
\hline Min & 7.4 & 7.4 & 7.4 & 7.3 & 7.6 & 7.5 & --- & --- & 6.6 & 6.7 & 7.3 & 7.4 \\
\hline Max & 8.4 & 8.4 & 8.6 & 8.4 & 8.2 & 7.9 & --- & --- & 7.9 & 8.3 & 8.8 & 8.9 \\
\hline Mean & 7.7 & 7.8 & 7.8 & 7.6 & 7.8 & 7.6 & --- & --- & 7.3 & 7.3 & 7.7 & 7.8 \\
\hline
\end{tabular}


Appendix Table 25. Monthly environmental data collected from the Salmon River near Sawtooth Hatchery (RKm 627.9) from August 2004 through July 2005.

\begin{tabular}{|c|c|c|c|c|c|c|c|c|c|c|c|c|}
\hline & Aug & Sep & Oct & Nov & Dec & Jan & Feb & Mar & Apr & May & Jun & Jul \\
\hline \multicolumn{13}{|c|}{ Temperature $\left({ }^{\circ} \mathrm{C}\right)$} \\
\hline Min & 10.1 & 10.3 & 1.3 & 0.0 & 0.0 & 0.0 & 0.0 & 0.0 & 1.0 & 3.6 & --- & 9.1 \\
\hline Max & 15.9 & 10.0 & 9.8 & 7.0 & 5.3 & 5.0 & 6.3 & 8.3 & 10.0 & 10.0 & 9.0 & 15.9 \\
\hline Mean & 12.7 & 10.5 & 6.9 & 3.0 & 1.4 & 1.1 & 1.5 & 3.7 & 6.2 & 8.3 & 10.6 & 13.0 \\
\hline \multicolumn{13}{|c|}{ Dissolved Oxygen (ppm) } \\
\hline Min & 8.1 & 10.0 & 10.1 & 11.6 & 11.9 & 10.2 & 12.2 & 10.1 & 11.7 & 7.3 & 9.7 & --- \\
\hline Max & 9.9 & 13.0 & 14.1 & 14.2 & 14.2 & 14.2 & 14.2 & 14.2 & 9.9 & 10.0 & 10.7 & --- \\
\hline Mean & 9.6 & 10.6 & 11.7 & 13.0 & 13.5 & 13.6 & 13.5 & 13.3 & 9.3 & 8.6 & 8.9 & --- \\
\hline \multicolumn{13}{|c|}{ Specific Conductance $(\mu \mathrm{S} / \mathrm{cm})$} \\
\hline Min & 132.0 & 131.0 & 136.0 & 133.0 & 126.0 & 132.0 & 136.0 & 128.0 & 112.0 & 100.0 & 71.0 & 92.0 \\
\hline Max & 152.0 & 159.0 & 174.0 & 172.0 & 149.0 & 149.0 & 154.0 & 153.0 & 157.0 & 99.0 & 96.0 & 145.0 \\
\hline Mean & 142.6 & 148.5 & 154.8 & 149.2 & 137.6 & 138.3 & 142.4 & 138.4 & 136.5 & 90.1 & 85.8 & 121.9 \\
\hline \multicolumn{13}{|c|}{ Turbidity (ntu) } \\
\hline Min & 0.0 & 0.0 & 0.0 & 0.5 & --- & --- & --- & --- & --- & --- & --- & --- \\
\hline Max & 4.3 & 30.5 & 43.9 & 49.9 & --- & --- & --- & --- & --- & --- & --- & --- \\
\hline Mean & 1.1 & 0.5 & 3.6 & 16.8 & --- & --- & --- & --- & --- & --- & --- & --- \\
\hline \multicolumn{13}{|c|}{ Depth (feet) } \\
\hline Min & 1.2 & 1.3 & 1.0 & 1.0 & 0.7 & 0.6 & 0.9 & 0.8 & 1.1 & 1.6 & 1.6 & 0.3 \\
\hline Max & 1.8 & 1.9 & 2.0 & 1.9 & 2.3 & 2.1 & 1.9 & 1.8 & 1.9 & 2.8 & 2.5 & 2.0 \\
\hline Mean & 1.6 & 1.6 & 1.6 & 1.5 & 1.4 & 1.4 & 1.4 & 1.3 & 1.5 & 2.1 & 2.0 & 1.7 \\
\hline \multicolumn{13}{|c|}{$\mathrm{pH}$} \\
\hline Min & 7.8 & 7.8 & 7.9 & 7.7 & 7.4 & 7.5 & 7.6 & 7.8 & 7.8 & 7.4 & 7.5 & 7.7 \\
\hline Max & 8.6 & 8.7 & 8.7 & 8.7 & 8.6 & 8.6 & 8.6 & 8.8 & 8.8 & 8.4 & 8.6 & 8.2 \\
\hline Mean & 8.2 & 8.2 & 8.2 & 8.2 & 8.1 & 8.1 & 8.1 & 8.2 & 8.1 & 7.8 & 7.9 & 8.1 \\
\hline
\end{tabular}


Appendix Table 26. Monthly environmental data collected from Valley Creek (RKm 609.4 from the mouth of the Salmon River) from August 2004 through July 2005.

\begin{tabular}{|c|c|c|c|c|c|c|c|c|c|c|c|c|}
\hline & Aug & Sep & Oct & Nov & Dec & Jan & $\mathrm{Feb}$ & Mar & Apr & May & Jun & Jul \\
\hline \multicolumn{13}{|c|}{ Temperature $\left({ }^{\circ} \mathrm{C}\right)$} \\
\hline Min & 8.5 & 5.2 & 0.4 & 0.0 & --- & --- & --- & --- & 0.3 & 2.1 & 4.6 & 8.7 \\
\hline Max & 15.9 & 15.9 & 14.1 & 6.4 & --- & --- & --- & --- & 13.1 & 15.1 & 15.9 & 15.9 \\
\hline Mean & 12.7 & 10.2 & 6.2 & 1.8 & --- & --- & --- & --- & 4.7 & 7.8 & 10.3 & 13.0 \\
\hline \multicolumn{13}{|c|}{ Dissolved Oxygen (ppm) } \\
\hline Min & 5.6 & 6.3 & 8.9 & 11.0 & --- & --- & --- & --- & 8.9 & 8.6 & 8.5 & 7.2 \\
\hline Max & 10.4 & 11.9 & 13.3 & 13.5 & --- & --- & --- & --- & 11.6 & 11.4 & 11.7 & 11.6 \\
\hline Mean & 8.1 & 9.7 & 11.2 & 12.5 & --- & --- & --- & --- & 10.4 & 10.1 & 9.9 & 9.1 \\
\hline \multicolumn{13}{|c|}{ Specific Conductance $(\mu \mathrm{S} / \mathrm{cm})$} \\
\hline Min & 68.0 & 64.0 & 68.0 & 71.0 & --- & --- & --- & --- & 48.0 & 40.0 & 39.0 & 48.0 \\
\hline Max & 81.0 & 81.0 & 79.0 & 96.0 & --- & --- & --- & --- & 80.0 & 58.0 & 50.0 & 68.0 \\
\hline Mean & 75.4 & 73.6 & 74.1 & 79.4 & --- & --- & --- & --- & 64.2 & 48.1 & 45.8 & 55.4 \\
\hline \multicolumn{13}{|c|}{ Turbidity (ntu) } \\
\hline Min & 0.2 & 0.0 & 0.1 & 0.2 & --- & --- & --- & --- & 0.9 & 2.1 & 1.3 & 3.3 \\
\hline Max & 33.0 & 45.7 & 46.8 & 44.8 & --- & --- & --- & --- & 49.3 & 46.2 & 49.0 & 36.2 \\
\hline Mean & 2.0 & 2.4 & 2.2 & 2.5 & --- & --- & --- & --- & 7.5 & 9.0 & 6.8 & 13.4 \\
\hline \multicolumn{13}{|c|}{ Depth (feet) } \\
\hline Min & 0.8 & 0.9 & 0.5 & 0.1 & --- & --- & --- & --- & 0.8 & 1.2 & 1.3 & 0.9 \\
\hline Max & 1.6 & 1.5 & 1.5 & 1.5 & --- & --- & --- & --- & 1.7 & 2.6 & 2.3 & 1.6 \\
\hline Mean & 1.3 & 1.2 & 1.1 & 1.2 & --- & --- & --- & --- & 1.2 & 1.8 & 1.7 & 1.3 \\
\hline \multicolumn{13}{|c|}{$\mathrm{pH}$} \\
\hline Min & 7.6 & 7.6 & 7.7 & 7.7 & --- & --- & --- & --- & 7.4 & 7.1 & 7.1 & 7.3 \\
\hline Max & 8.5 & 8.5 & 8.2 & 8.1 & --- & --- & --- & --- & 8.3 & 8.7 & 8.2 & 8.4 \\
\hline Mean & 8.0 & 7.9 & 7.9 & 7.9 & --- & --- & --- & --- & 7.7 & 7.6 & 7.5 & 7.7 \\
\hline
\end{tabular}


Appendix Table 27. Monthly environmental data collected from Secesh River $(27 \mathrm{~km}$ upstream from its confluence with the South Fork Salmon River) from August 2004 through July 2005.

\begin{tabular}{|c|c|c|c|c|c|c|c|c|c|c|c|c|}
\hline & Aug & Sep & Oct & Nov & Dec & Jan & Feb & Mar & Apr & May & Jun & Jul \\
\hline \multicolumn{13}{|c|}{ Temperature $\left({ }^{\circ} \mathrm{C}\right)$} \\
\hline Min & --- & --- & --- & -0.5 & -0.4 & -0.4 & -0.4 & -0.4 & -0.5 & 0.5 & 3.4 & 7.9 \\
\hline Max & --- & --- & --- & 1.9 & -0.4 & -0.4 & -0.4 & -0.4 & 7.2 & 10.2 & 14.7 & 15.9 \\
\hline Mean & --- & --- & --- & -0.3 & -0.4 & -0.4 & -0.4 & -0.4 & 1.5 & 4.6 & 7.9 & 12.6 \\
\hline \multicolumn{13}{|c|}{ Dissolved Oxygen (ppm) } \\
\hline Min & --- & --- & --- & 11.9 & 10.7 & 10.6 & 11.3 & 11.5 & 10.6 & 9.8 & 8.8 & 6.0 \\
\hline Max & --- & --- & --- & 14.2 & 12.2 & 12.3 & 12.6 & 13.0 & 12.7 & 12.5 & 11.8 & 10.6 \\
\hline Mean & --- & --- & --- & 12.8 & 11.3 & 11.2 & 11.7 & 12.1 & 11.8 & 11.2 & 10.4 & 8.4 \\
\hline \multicolumn{13}{|c|}{ Specific Conductance $(\mu \mathrm{S} / \mathrm{cm})$} \\
\hline Min & --- & --- & --- & 21.0 & 31.0 & 33.0 & 36.0 & 34.0 & 20.0 & 16.0 & 18.0 & 25.0 \\
\hline Max & --- & --- & --- & 36.0 & 36.0 & 36.0 & 38.0 & 38.0 & 38.0 & 23.0 & 27.0 & 35.0 \\
\hline Mean & --- & --- & --- & 31.4 & 33.8 & 35.2 & 36.8 & 35.8 & 28.1 & 19.1 & 23.0 & 30.8 \\
\hline \multicolumn{13}{|c|}{ Turbidity (ntu) } \\
\hline Min & --- & --- & --- & 0.0 & 0.0 & 0.0 & 0.0 & 0.0 & 0.4 & 1.2 & 0.5 & 0.0 \\
\hline Max & --- & --- & --- & 9.8 & 1.7 & 1.1 & 0.8 & 2.4 & 30.6 & 37.3 & 6.5 & 3.7 \\
\hline Mean & --- & --- & --- & 0.5 & 0.3 & 0.3 & 0.1 & 0.6 & 3.4 & 4.0 & 1.3 & 0.4 \\
\hline \multicolumn{13}{|c|}{ Depth (feet) } \\
\hline Min & --- & --- & --- & 1.7 & 1.8 & 1.8 & 2.3 & 2.0 & 1.2 & 2.4 & 2.0 & 1.4 \\
\hline Max & --- & --- & --- & 3.1 & 3.2 & 3.3 & 3.3 & 3.4 & 3.4 & 3.4 & 3.4 & 2.2 \\
\hline Mean & --- & --- & --- & 2.1 & 2.6 & 2.7 & 2.8 & 2.8 & 2.0 & 3.0 & 2.5 & 1.7 \\
\hline \multicolumn{13}{|c|}{$\mathrm{pH}$} \\
\hline Min & --- & --- & --- & 6.9 & 6.8 & 6.9 & 6.9 & 6.9 & 6.8 & 6.5 & 6.7 & 6.7 \\
\hline Max & --- & --- & --- & 7.4 & 7.1 & 7.2 & 7.2 & 7.3 & 7.3 & 7.2 & 7.3 & 7.9 \\
\hline Mean & --- & --- & --- & 7.2 & 6.9 & 7.0 & 7.0 & 7.0 & 7.0 & 6.9 & 6.9 & 7.1 \\
\hline
\end{tabular}


Appendix Table 28. Monthly environmental data collected from South Fork Salmon River (112 km from its confluence with the Salmon River) from August 2004 through July 2005.

\begin{tabular}{|c|c|c|c|c|c|c|c|c|c|c|c|c|}
\hline & Aug & Sep & Oct & Nov & Dec & Jan & Feb & Mar & Apr & May & Jun & Jul \\
\hline \multicolumn{13}{|c|}{ Temperature $\left({ }^{\circ} \mathrm{C}\right)$} \\
\hline Min & 7.9 & 5.0 & 0.2 & -0.1 & -0.1 & -0.1 & -0.1 & -0.1 & -0.1 & 1.4 & 3.3 & 7.8 \\
\hline Max & 15.9 & 15.8 & 10.7 & 3.8 & 1.2 & 1.9 & 2.4 & 4.1 & 7.9 & 9.5 & 14.5 & 15.9 \\
\hline Mean & 13.0 & 9.5 & 5.1 & 0.9 & 0.1 & 0.2 & 0.1 & 1.4 & 3.3 & 4.9 & 7.9 & 12.7 \\
\hline \multicolumn{13}{|c|}{ Dissolved Oxygen (ppm) } \\
\hline Min & --- & --- & --- & 2.0 & 1.2 & 1.2 & 0.9 & 3.1 & 11.7 & 14.1 & 9.6 & 7.2 \\
\hline Max & --- & --- & --- & 13.1 & 13.6 & 14.1 & 14.2 & 14.2 & 14.2 & 14.1 & 14.2 & 14.2 \\
\hline Mean & --- & --- & --- & 9.8 & 7.9 & 7.7 & 6.8 & 11.2 & 13.5 & 14.1 & 13.4 & 12.2 \\
\hline \multicolumn{13}{|c|}{ Specific Conductance $(\mu \mathrm{S} / \mathrm{cm})$} \\
\hline Min & 38.0 & 43.0 & 47.0 & 42.0 & 40.0 & 40.0 & 40.0 & 39.0 & 29.0 & 19.0 & 21.0 & 30.0 \\
\hline Max & 51.0 & 53.0 & 57.0 & 69.0 & 59.0 & 57.0 & 61.0 & 59.0 & 52.0 & 33.0 & 31.0 & 47.0 \\
\hline Mean & 46.7 & 49.4 & 51.6 & 53.0 & 52.8 & 53.0 & 55.2 & 51.8 & 40.6 & 24.8 & 26.0 & 39.0 \\
\hline \multicolumn{13}{|c|}{ Turbidity (ntu) } \\
\hline Min & 0.0 & 0.2 & --- & 0.0 & 0.0 & 0.0 & 0.0 & 0.0 & 1.1 & 1.8 & 1.0 & 0.1 \\
\hline Max & 33.4 & 49.7 & --- & 2.2 & 3.5 & 2.7 & 8.0 & 15.2 & 17.9 & 48.8 & 16.0 & 19.6 \\
\hline Mean & 4.6 & 15.0 & --- & 0.2 & 0.4 & 0.2 & 0.3 & 1.1 & 3.3 & 11.9 & 2.6 & 0.7 \\
\hline \multicolumn{13}{|c|}{ Depth (feet) } \\
\hline Min & 0.5 & 0.5 & 0.2 & 0.5 & 0.3 & 0.4 & 0.5 & 0.2 & 0.5 & 1.3 & 1.1 & 0.4 \\
\hline Max & 1.2 & 1.1 & 1.2 & 1.7 & 2.3 & 2.1 & 2.0 & 1.3 & 1.6 & 3.4 & 2.2 & 1.3 \\
\hline Mean & 0.9 & 0.8 & 0.7 & 0.9 & 1.4 & 1.2 & 1.0 & 0.7 & 1.1 & 2.0 & 1.5 & 0.9 \\
\hline \multicolumn{13}{|c|}{$\mathrm{pH}$} \\
\hline Min & 7.3 & 7.3 & 7.4 & 7.4 & 7.3 & 7.5 & 7.6 & 7.4 & 7.1 & 6.7 & 7.0 & 7.2 \\
\hline Max & 8.6 & 8.6 & 8.4 & 8.3 & 7.8 & 8.1 & 8.1 & 8.2 & 7.8 & 7.8 & 8.2 & 8.8 \\
\hline Mean & 7.6 & 7.7 & 7.6 & 7.6 & 7.6 & 7.6 & 7.7 & 7.7 & 7.4 & 7.1 & 7.3 & 7.6 \\
\hline
\end{tabular}


Appendix Table 29. Monthly air temperature, precipitation, and snowfall at three weather stations and mean monthly stream flow data at two sites in the Salmon River drainage, Idaho, August 2004 to July 2005.

\begin{tabular}{|c|c|c|c|c|c|c|c|c|c|c|c|c|}
\hline & Aug & Sep & Oct & Nov & Dec & Jan & Feb & Mar & Apr & May & Jun & Jul \\
\hline & \multicolumn{12}{|c|}{$\underline{\text { Stanley }}$} \\
\hline \multicolumn{13}{|l|}{ Air temperature $\left({ }^{\circ} \mathrm{C}\right)$} \\
\hline Min & 2.3 & -1.9 & -5.8 & -11.6 & -13.1 & -16.9 & -20.6 & -11.6 & -6.3 & -1.8 & -0.2 & 2.0 \\
\hline Max & 24.8 & 18.0 & 12.3 & 2.4 & -0.7 & -3.2 & 1.8 & 6.5 & 10.8 & 15.0 & 17.7 & 27.5 \\
\hline Mean & 13.6 & 8.1 & 3.2 & -4.6 & -6.9 & -10.1 & -9.4 & -2.6 & 2.2 & 6.6 & 8.7 & 14.7 \\
\hline Precipitation (cm) & 0.0 & 0.0 & 0.0 & 0.1 & 3.1 & 1.9 & 0.8 & 5.8 & 0.0 & 0.0 & 0.5 & 0.0 \\
\hline Snowfall (cm) & 0.0 & 0.0 & 8.9 & 7.6 & 45.7 & 35.6 & 8.9 & 26.7 & 0.0 & 0.0 & 0.0 & 0.0 \\
\hline & \multicolumn{12}{|c|}{ Taylor Ranch } \\
\hline \multicolumn{13}{|l|}{ Air temperature $\left({ }^{\circ} \mathrm{C}\right)$} \\
\hline Min & 10.2 & 5.7 & 1.6 & -4.6 & -5.5 & -9.3 & -8.0 & -2.1 & 0.9 & 4.8 & 6.8 & 10.6 \\
\hline Max & 29.1 & 21.8 & 15.7 & 4.4 & 1.3 & 0.1 & 4.5 & 10.8 & 14.5 & 19.7 & 21.6 & 32.7 \\
\hline Mean & 19.6 & 13.8 & 8.7 & -0.1 & -2.1 & -4.6 & -1.7 & 4.3 & 7.7 & 12.3 & 14.2 & 21.7 \\
\hline Precipitation (cm) & 5.2 & 5.2 & 0.2 & 1.2 & 2.6 & 0.9 & 0.3 & 1.4 & 3.0 & 5.8 & 7.5 & 0.4 \\
\hline Snowfall $(\mathrm{cm})$ & 0.0 & 0.0 & 0.0 & 3.8 & 12.7 & 17.5 & 7.4 & 6.6 & 0.0 & 0.0 & 0.0 & 0.0 \\
\hline & \multicolumn{12}{|c|}{$\underline{\text { Middle Fork Lodge }}$} \\
\hline \multicolumn{13}{|l|}{ Air temperature $\left({ }^{\circ} \mathrm{C}\right)$} \\
\hline Min & 8.3 & 3.7 & -0.3 & -6.0 & -7.0 & -10.2 & -9.5 & -4.1 & -1.4 & 3.3 & 5.0 & 8.6 \\
\hline Max & 29.1 & 22.2 & 16.3 & 6.2 & 2.5 & 2.1 & 6.0 & 11.4 & 14.8 & 18.6 & 21.0 & 30.5 \\
\hline Mean & 18.6 & 12.9 & 8.0 & 0.1 & -2.3 & -4.1 & -1.7 & 3.7 & 6.7 & 11.0 & 13.0 & 19.5 \\
\hline Precipitation (cm) & 5.2 & 4.4 & 3.0 & 1.2 & 3.5 & 1.5 & 0.5 & 2.1 & 1.6 & 6.4 & 6.7 & 0.7 \\
\hline \multirow[t]{2}{*}{ Snowfall (cm) } & 0.0 & 0.0 & 0.0 & 5.1 & 43.9 & 23.4 & 7.6 & 4.6 & 3.8 & 0.0 & 0.0 & 0.0 \\
\hline & \multicolumn{12}{|c|}{ Valley Creek } \\
\hline \multirow[t]{2}{*}{ Stream flow $\left(\mathrm{m}^{3} / \mathrm{s}\right)$} & 2.3 & 2.8 & 2.5 & 2.3 & 2.0 & 1.9 & 1.8 & 2.1 & 5.1 & 11.7 & 9.8 & 4.1 \\
\hline & \multicolumn{12}{|c|}{$\underline{\text { Salmon River at Shoup, Idaho }}$} \\
\hline Stream flow $\left(\mathrm{m}^{3} / \mathrm{s}\right)$ & 36.2 & 34.3 & 29.7 & 26.0 & 24.1 & 21.6 & 22.2 & 27.3 & 51.2 & 202.8 & 150.3 & 56.4 \\
\hline
\end{tabular}


Upper Salmon River Trap

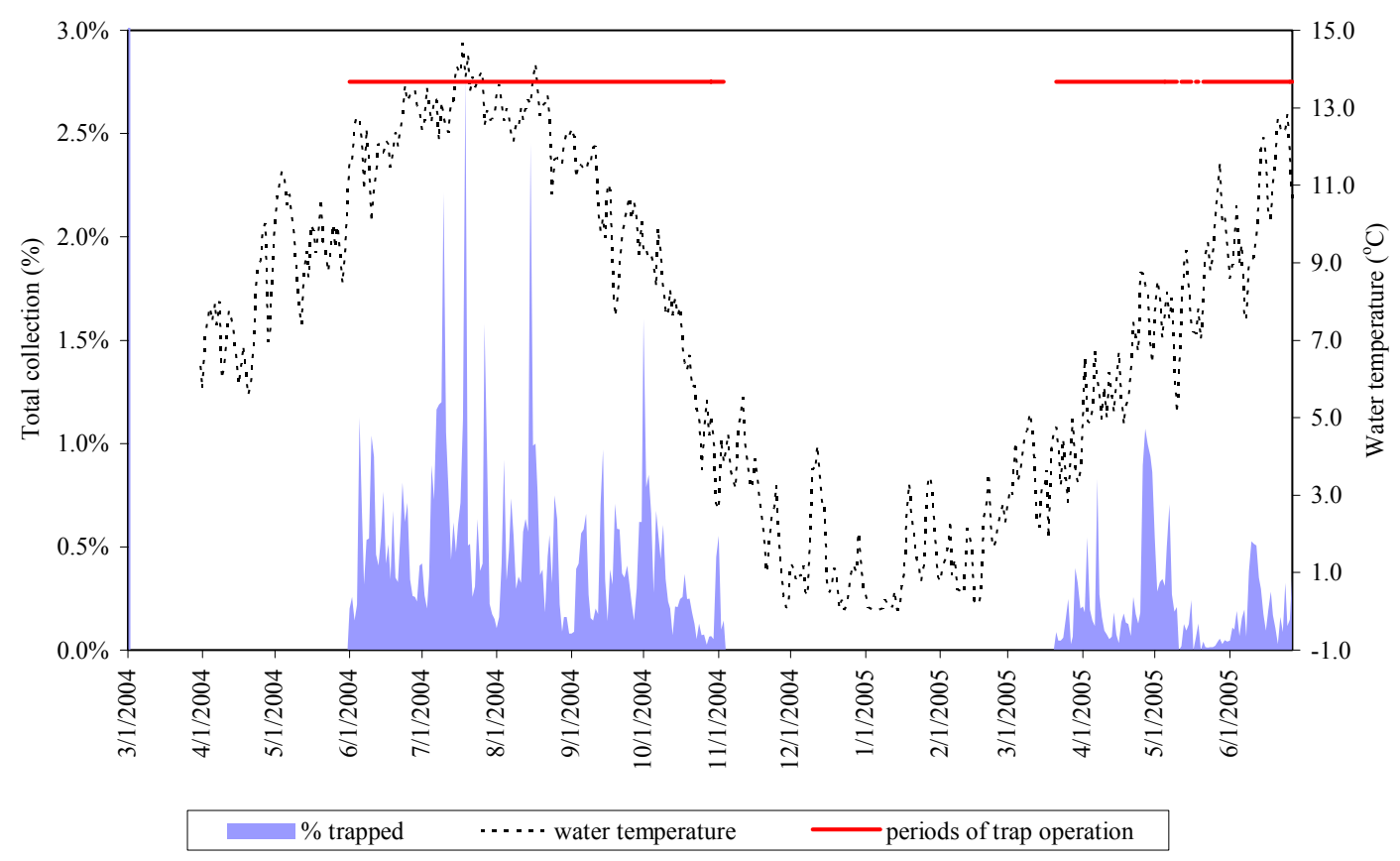

Marsh Creek Trap

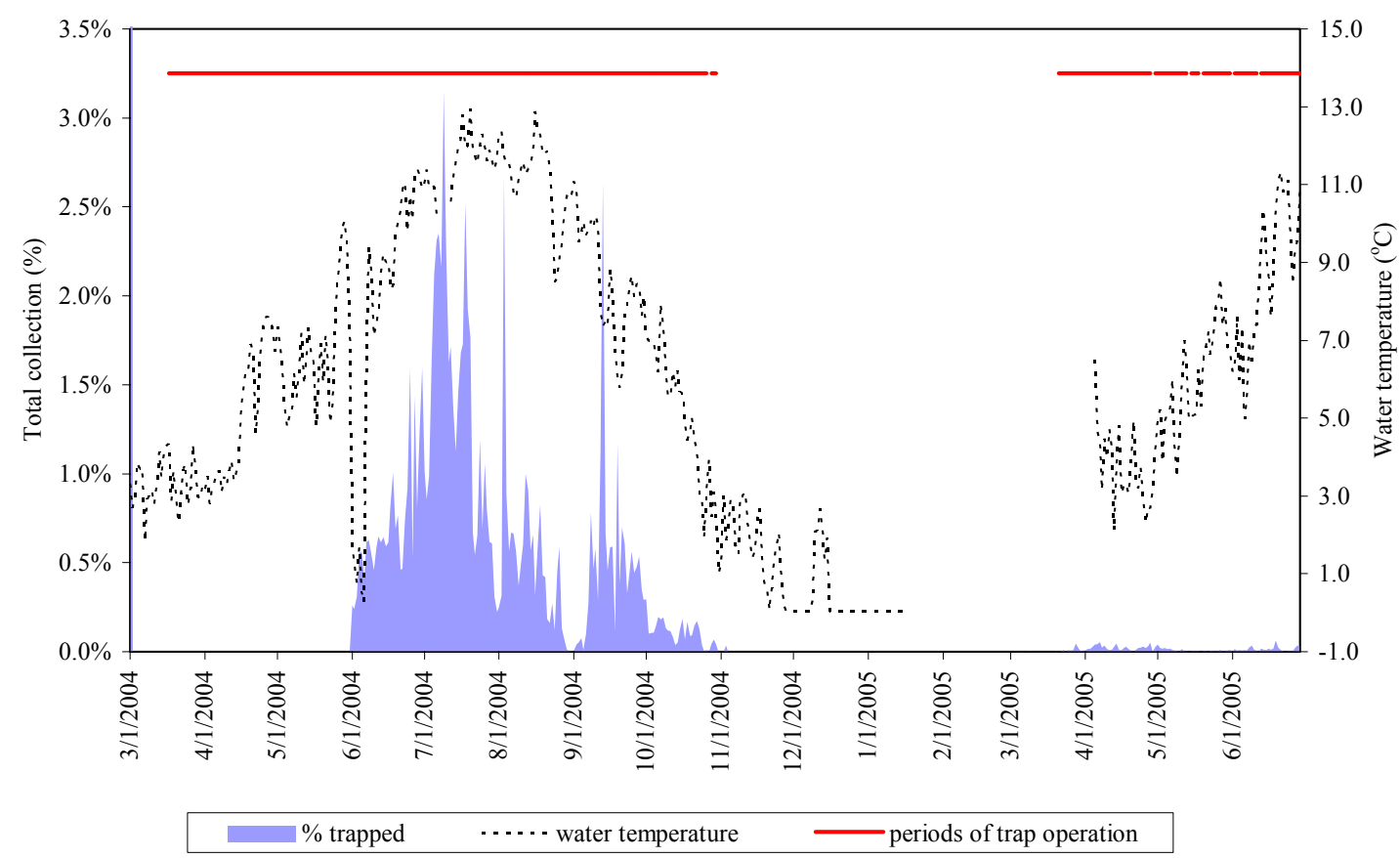

Appendix Figure 1. Daily passage of wild Chinook salmon fry, parr, and smolts at four migrant traps, expressed as percentages of total collected, and plotted against average daily water temperatures collected near traps. Periods of trap operation are also shown. 


\section{South Fork Salmon River Trap}

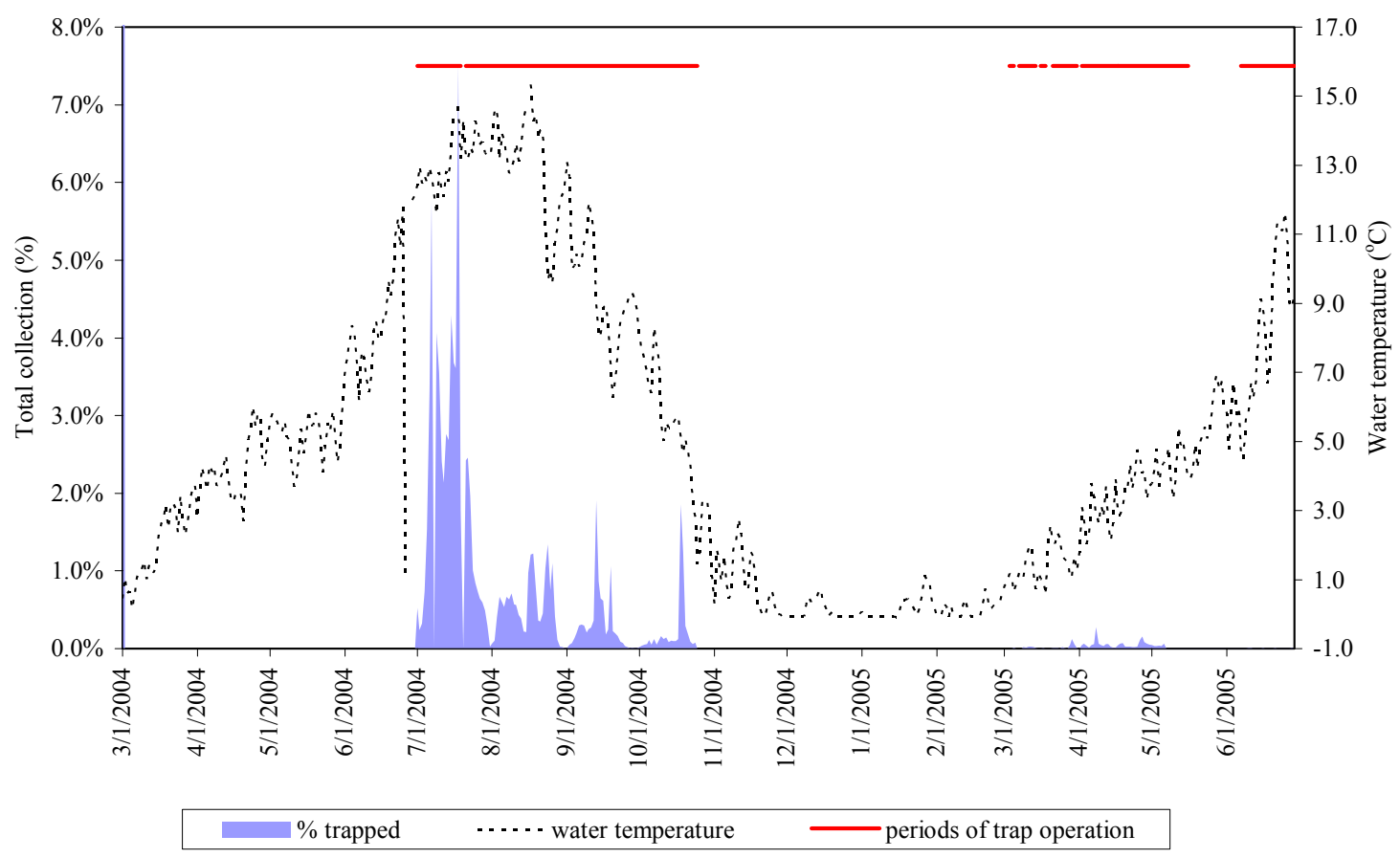

Secesh River Trap

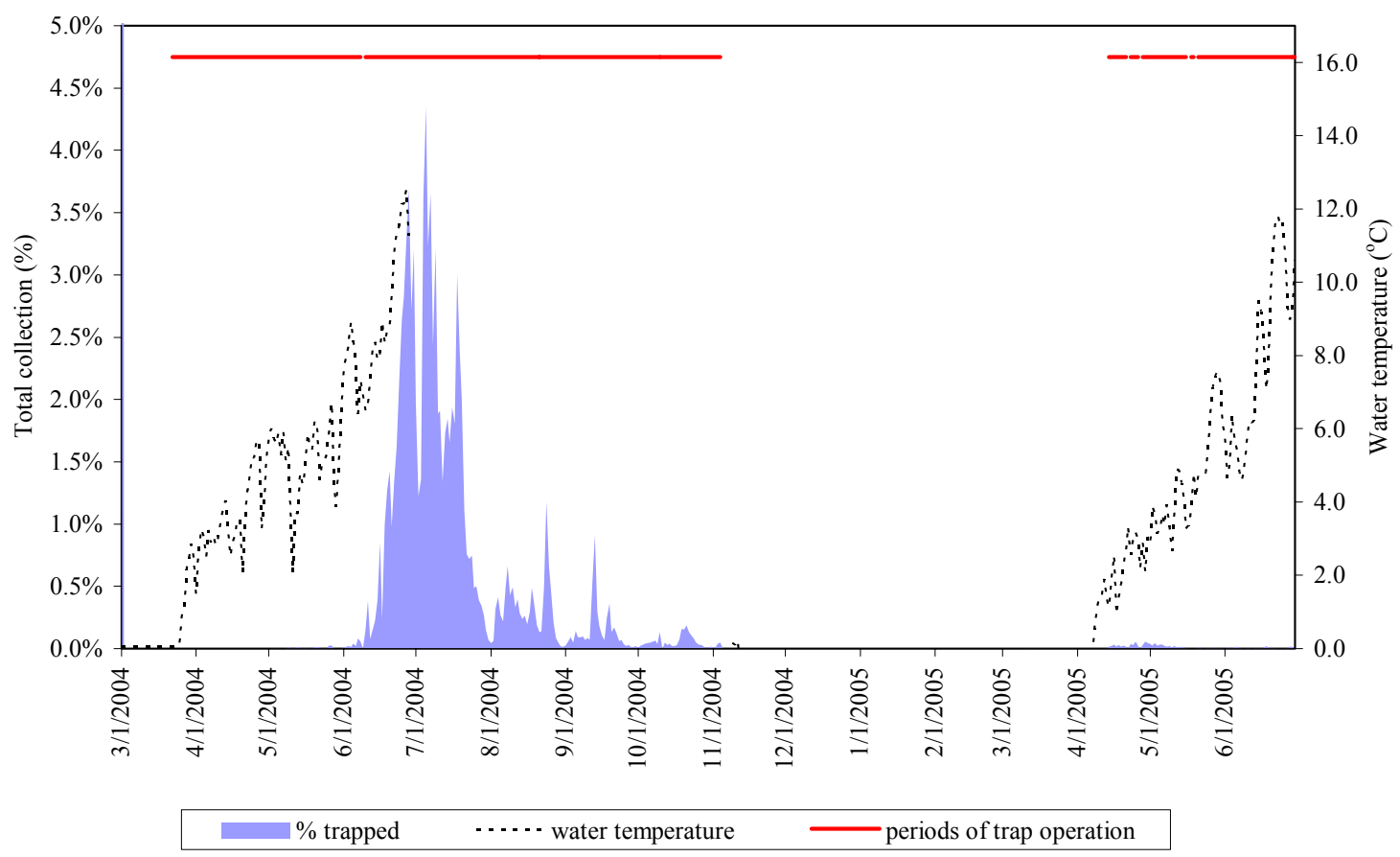

Appendix Figure 1. Continued. 
Upper Salmon River Trap

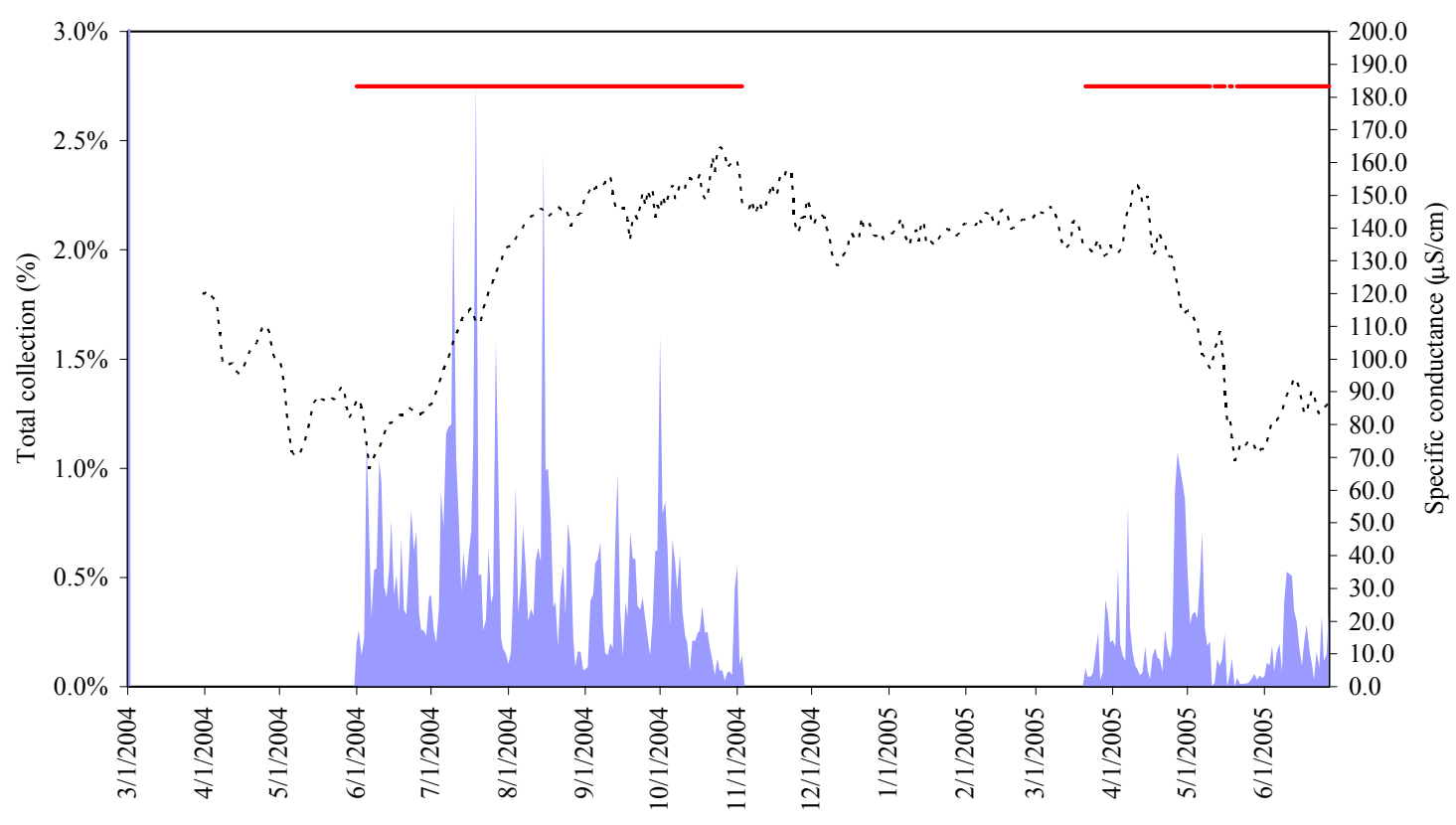

$\%$ trapped $\quad \cdots \cdots$ specific conductance $\quad \longrightarrow$ periods of trap operation

Marsh Creek Trap

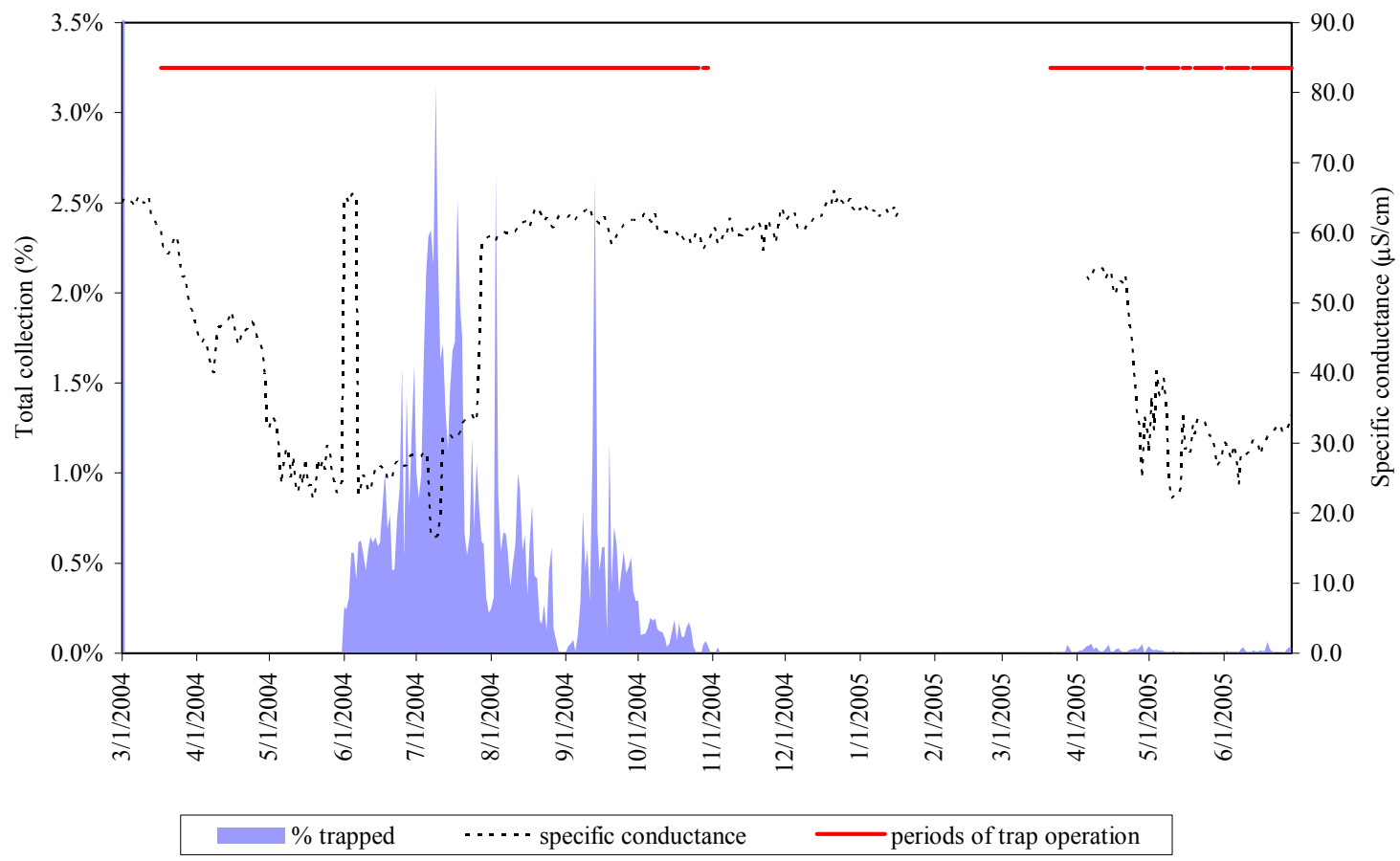

Appendix Figure 2. Daily passage of wild Chinook salmon fry, parr, and smolts at four migrant traps, expressed as percentages of total collected, and plotted against average daily specific conductance collected near traps. Periods of trap operation are also shown. 
South Fork Salmon River Trap

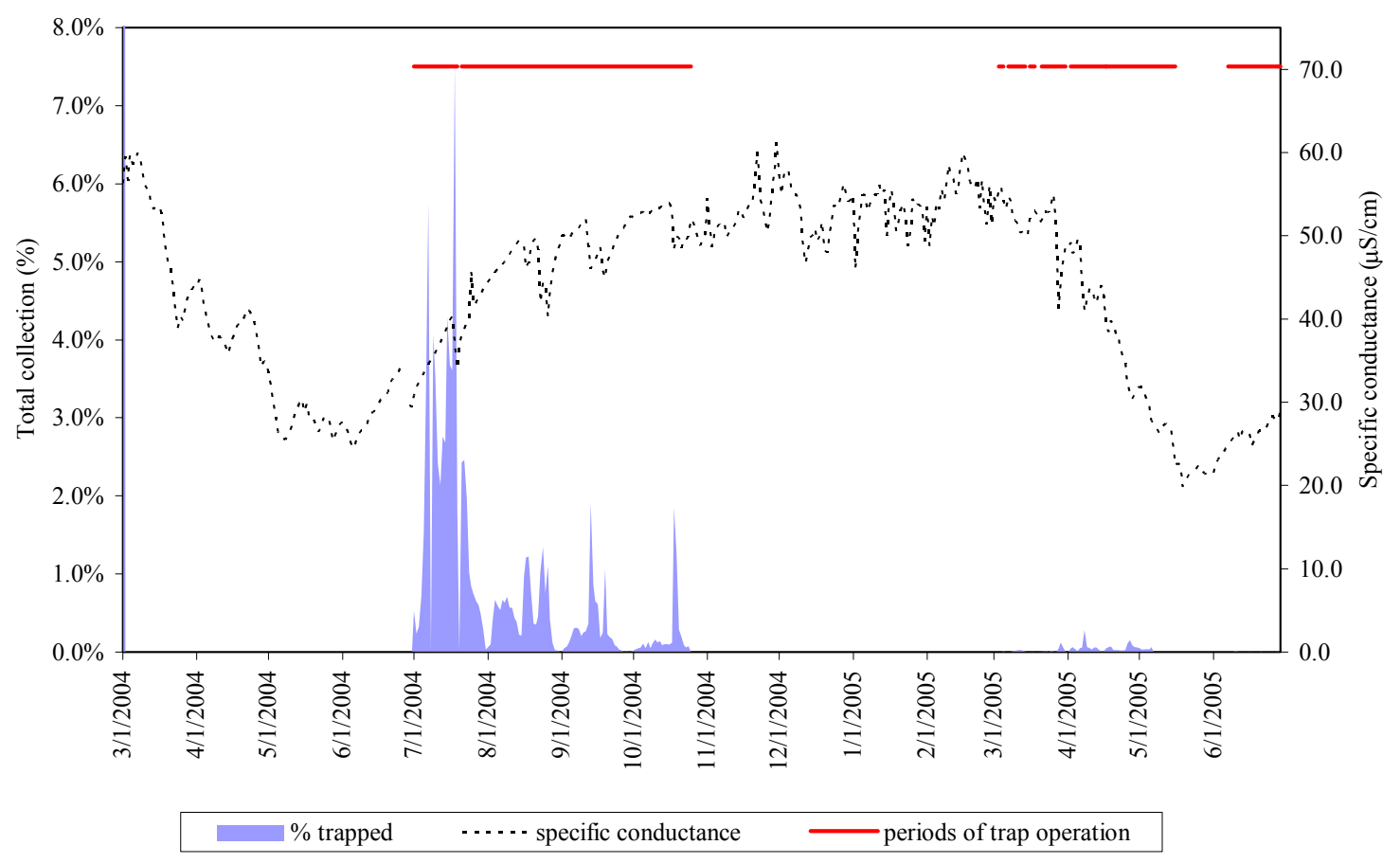

\section{Secesh River Trap}

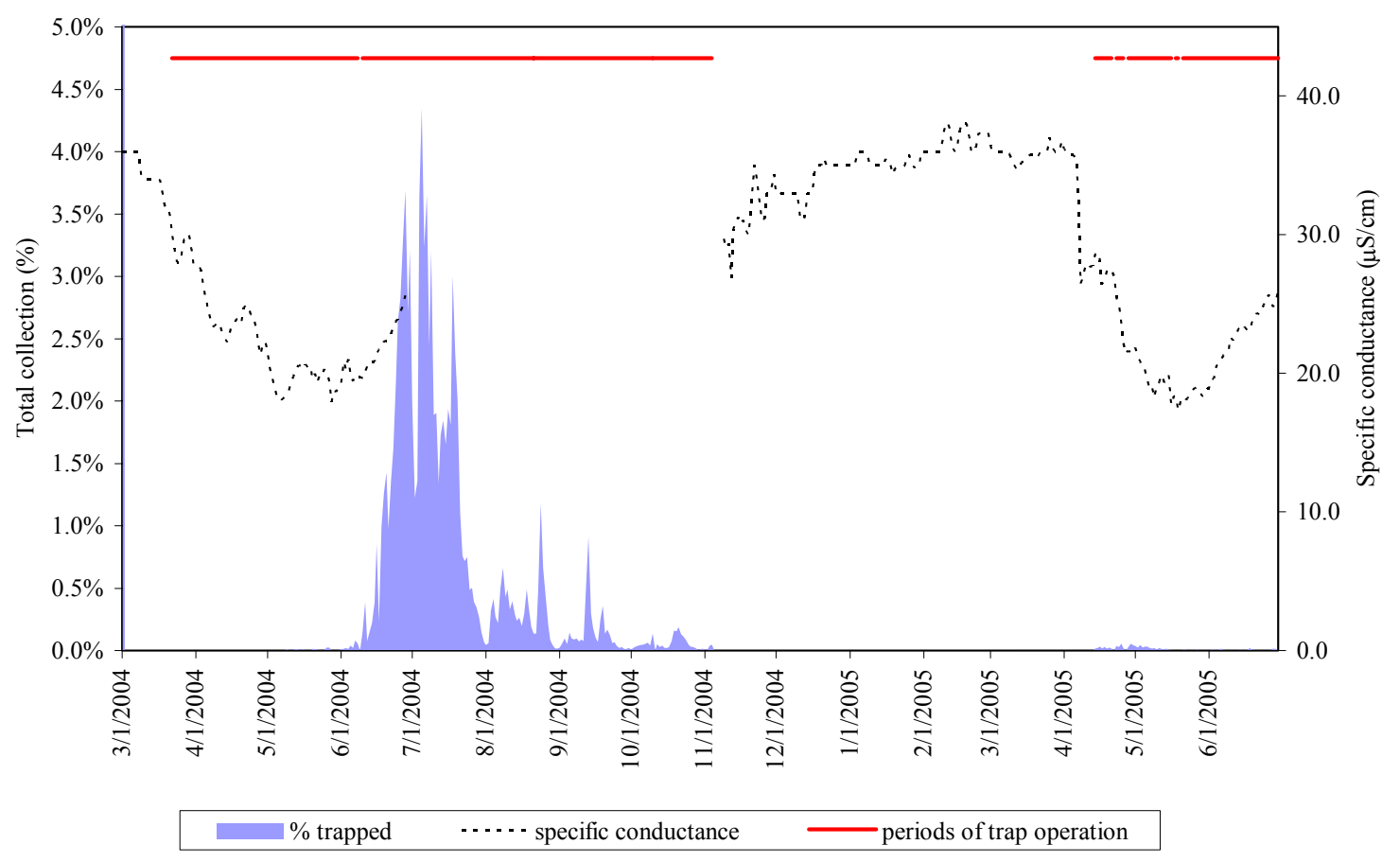

\section{Appendix Figure 2. Continued.}




\section{Upper Salmon River Trap}

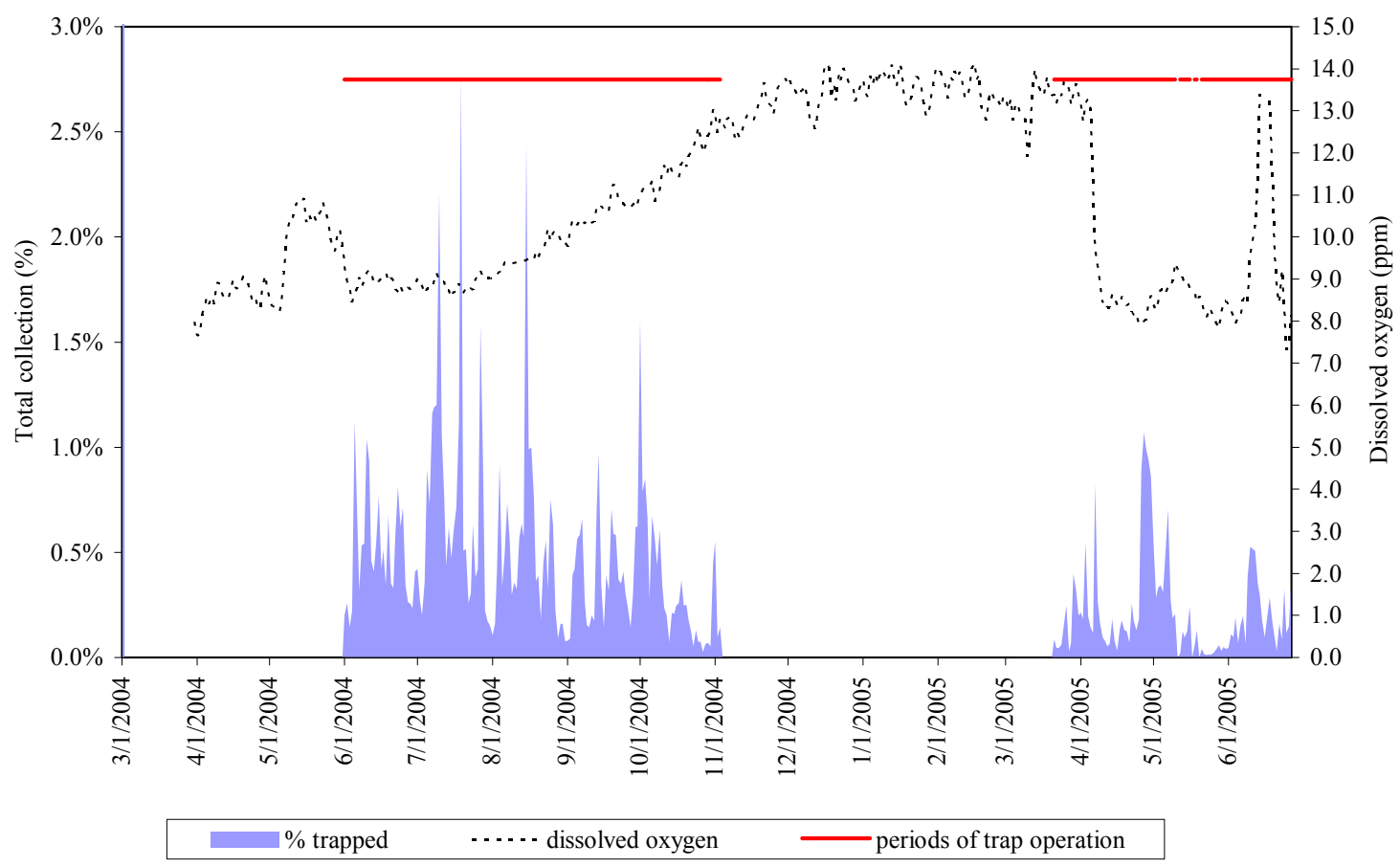

Marsh Creek Trap

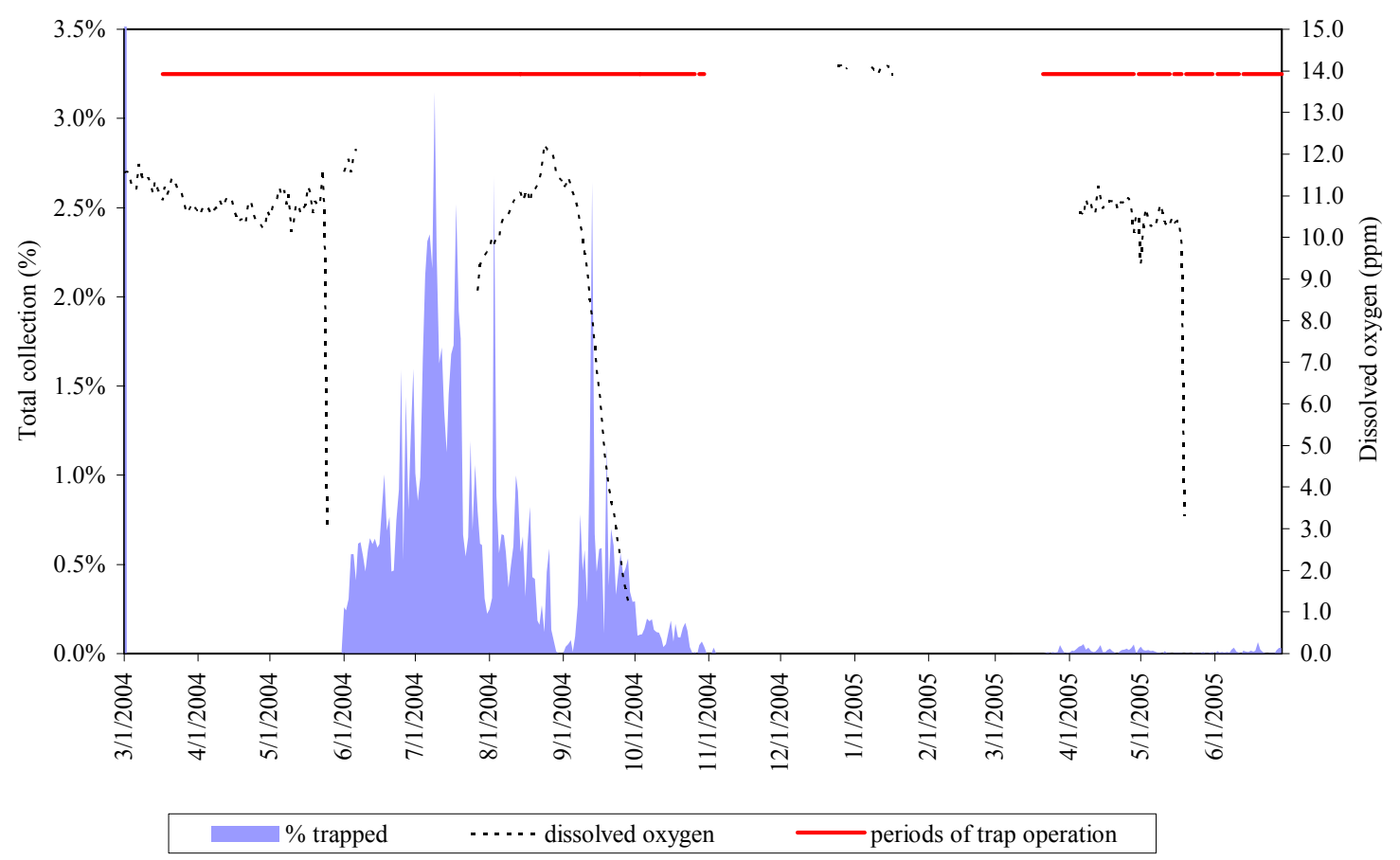

Appendix Figure 3. Daily passage of wild Chinook salmon fry, parr, and smolts at four migrant traps, expressed as percentages of total collected, and plotted against average daily dissolved oxygen collected near traps. Periods of trap operation are also shown. 
South Fork Salmon River Trap

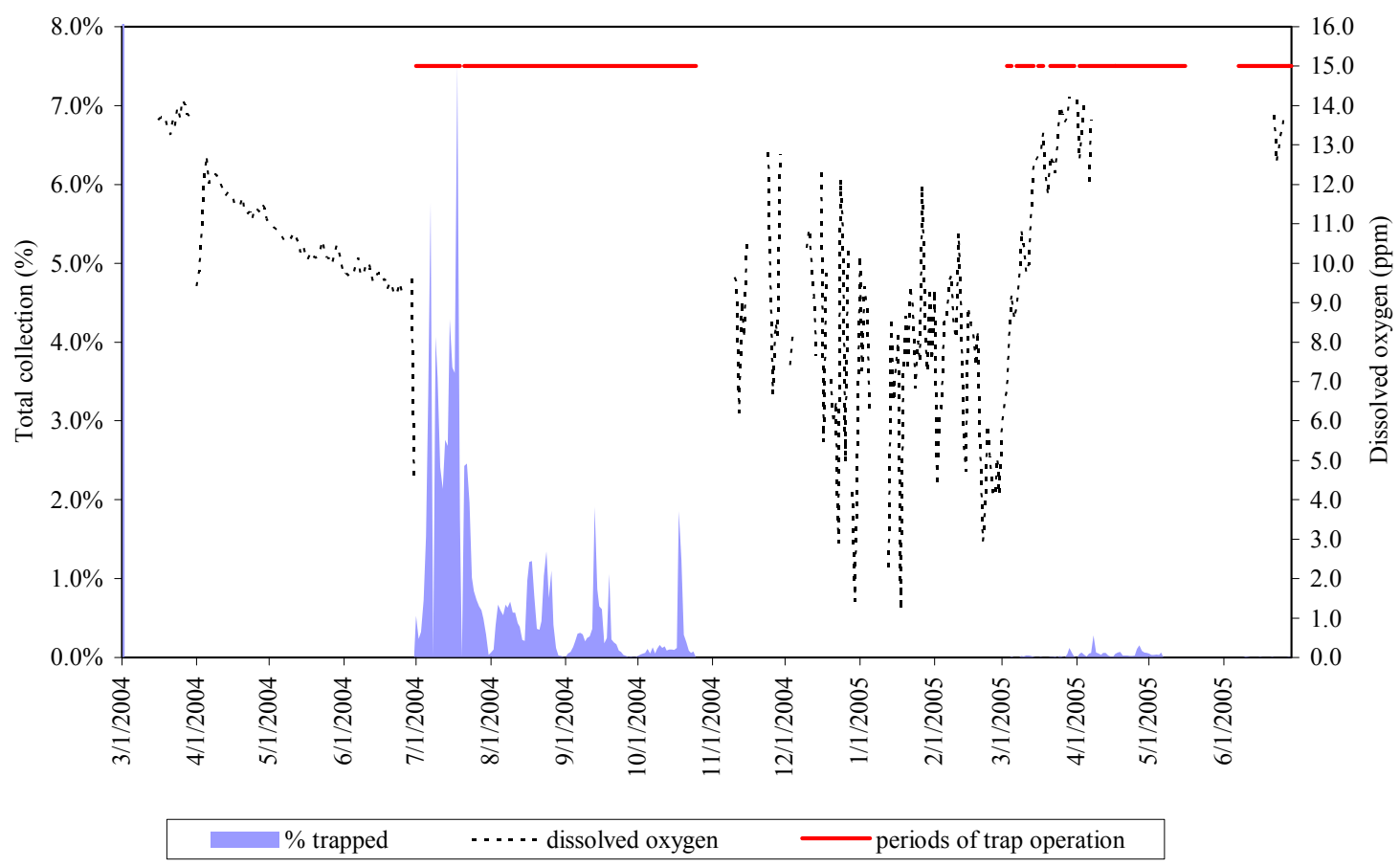

Secesh River Trap

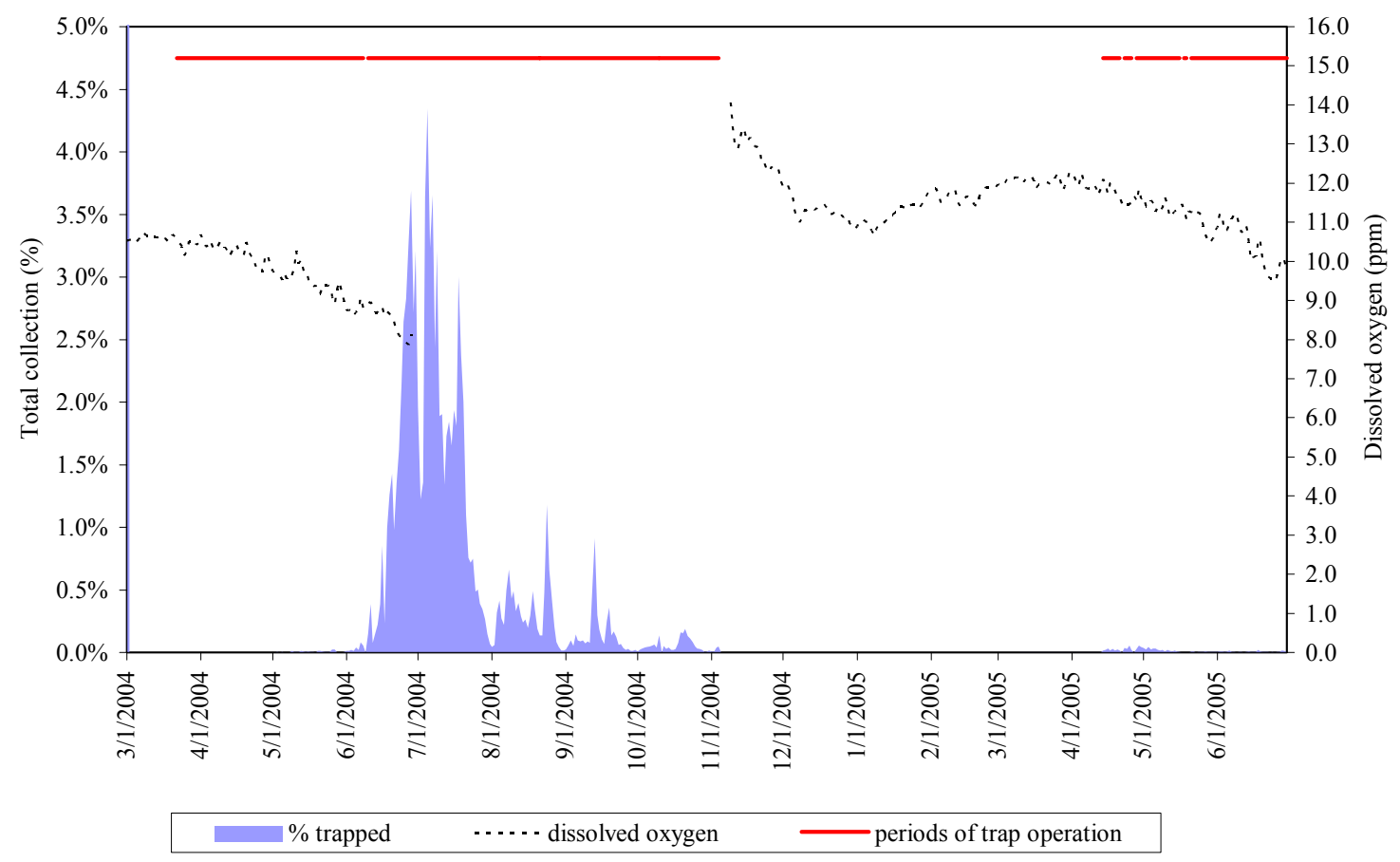

Appendix Figure 3. Continued. 


\section{Upper Salmon River Trap}

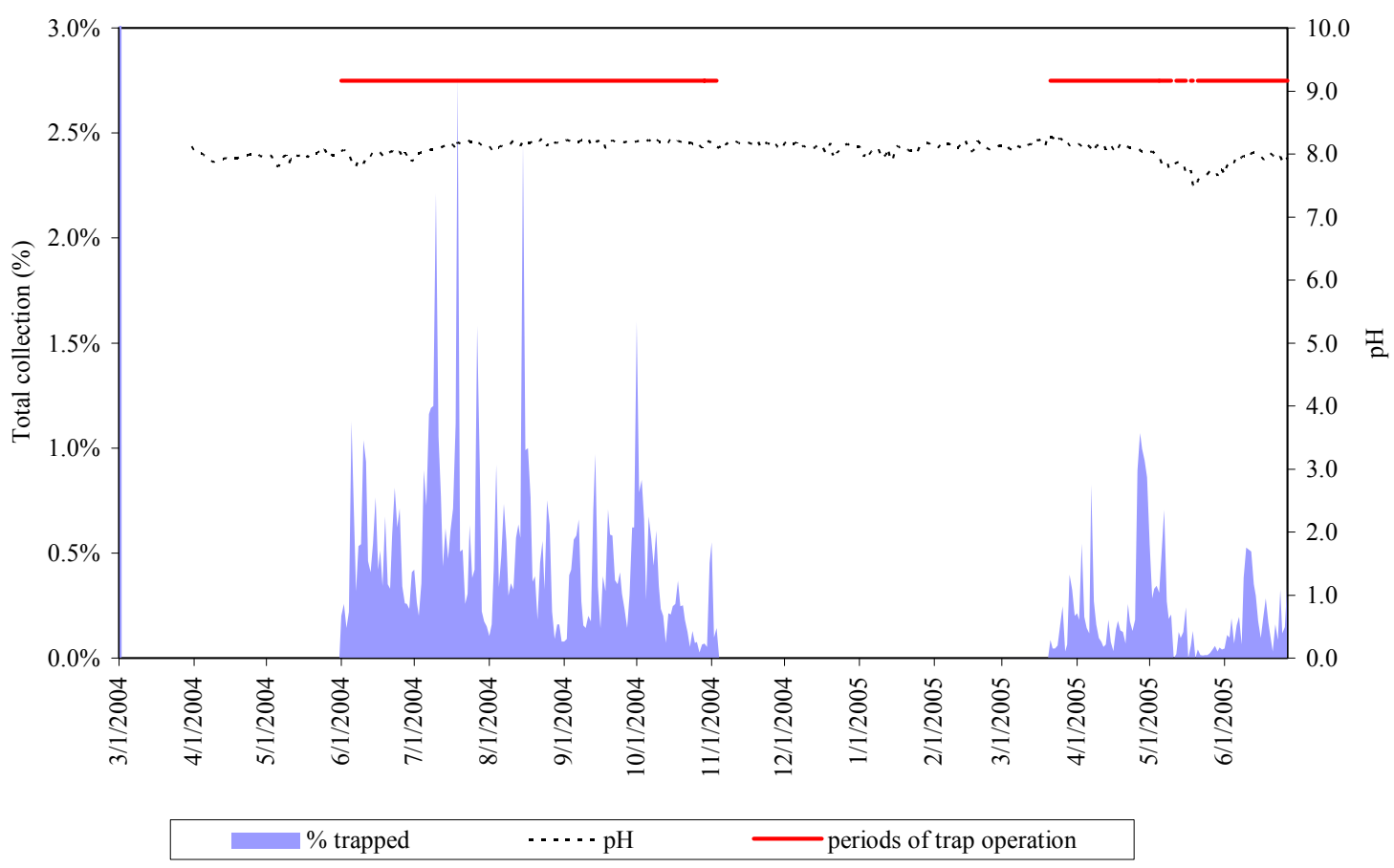

Marsh Creek Trap

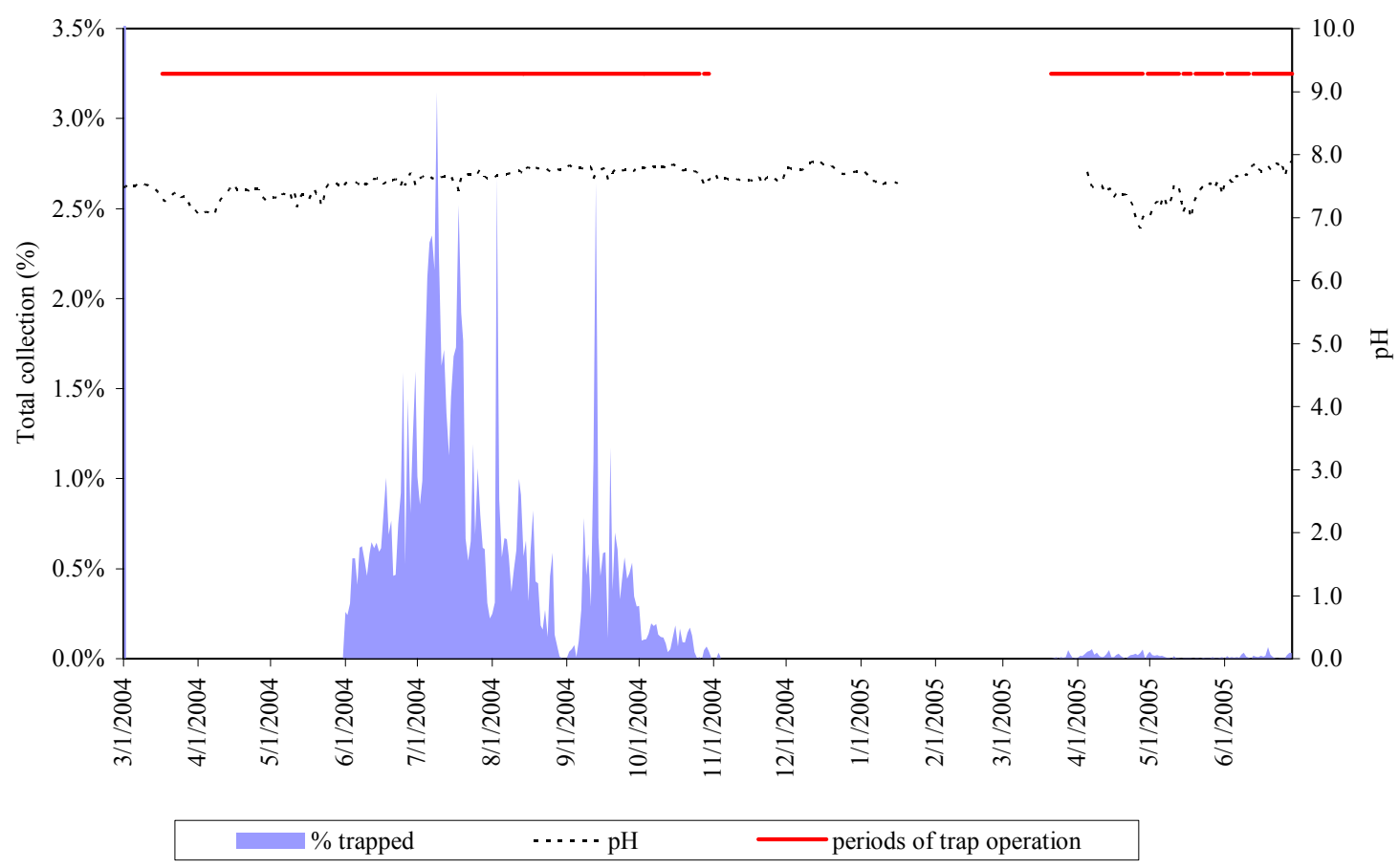

Appendix Figure 4. Daily passage of wild Chinook salmon fry, parr, and smolts at four migrant traps, expressed as percentages of total collected, and plotted against average daily $\mathrm{pH}$ collected near traps. Periods of trap operation are also shown. 


\section{South Fork Salmon River Trap}
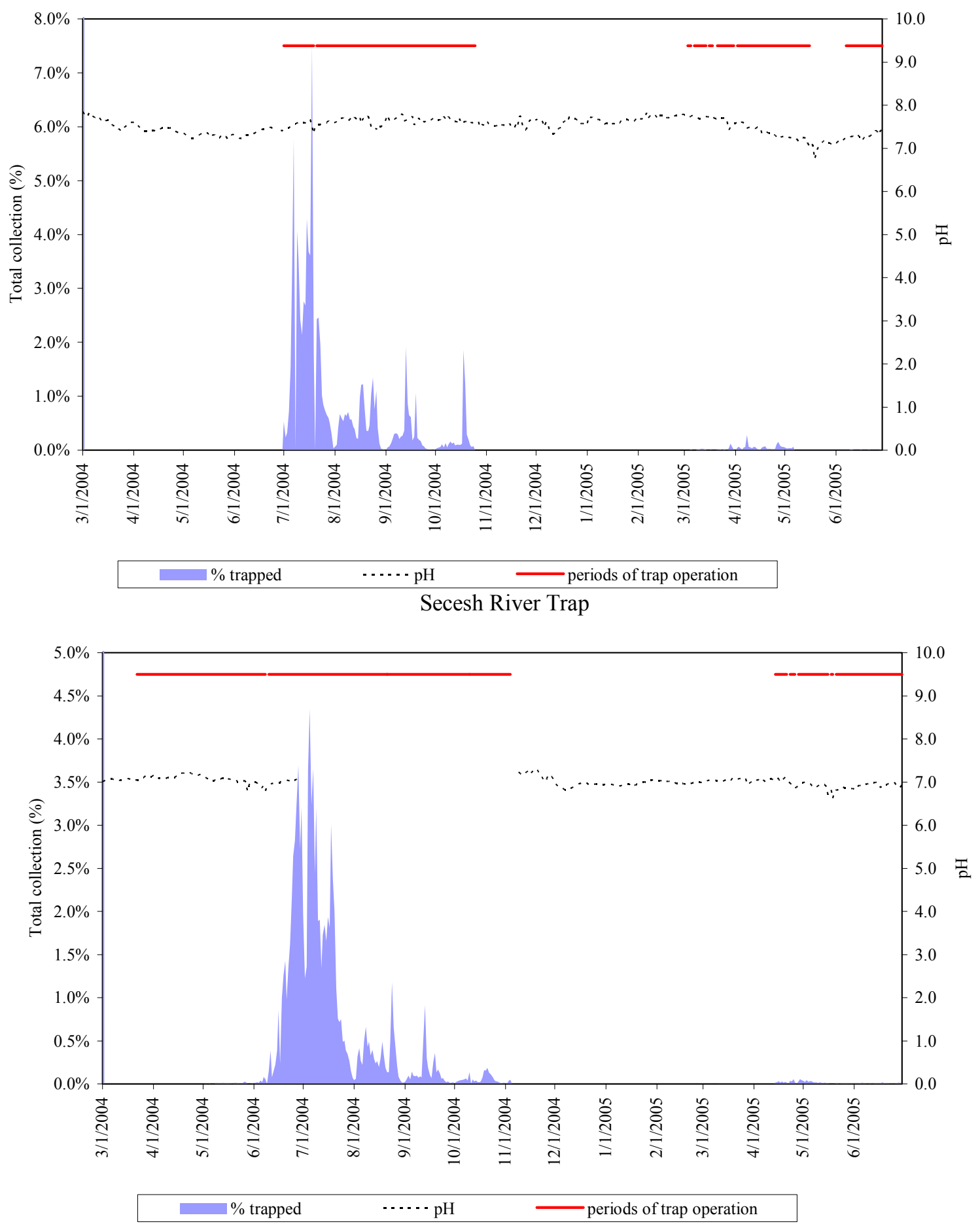

\section{Appendix Figure 4. Continued.}


Upper Salmon River Trap

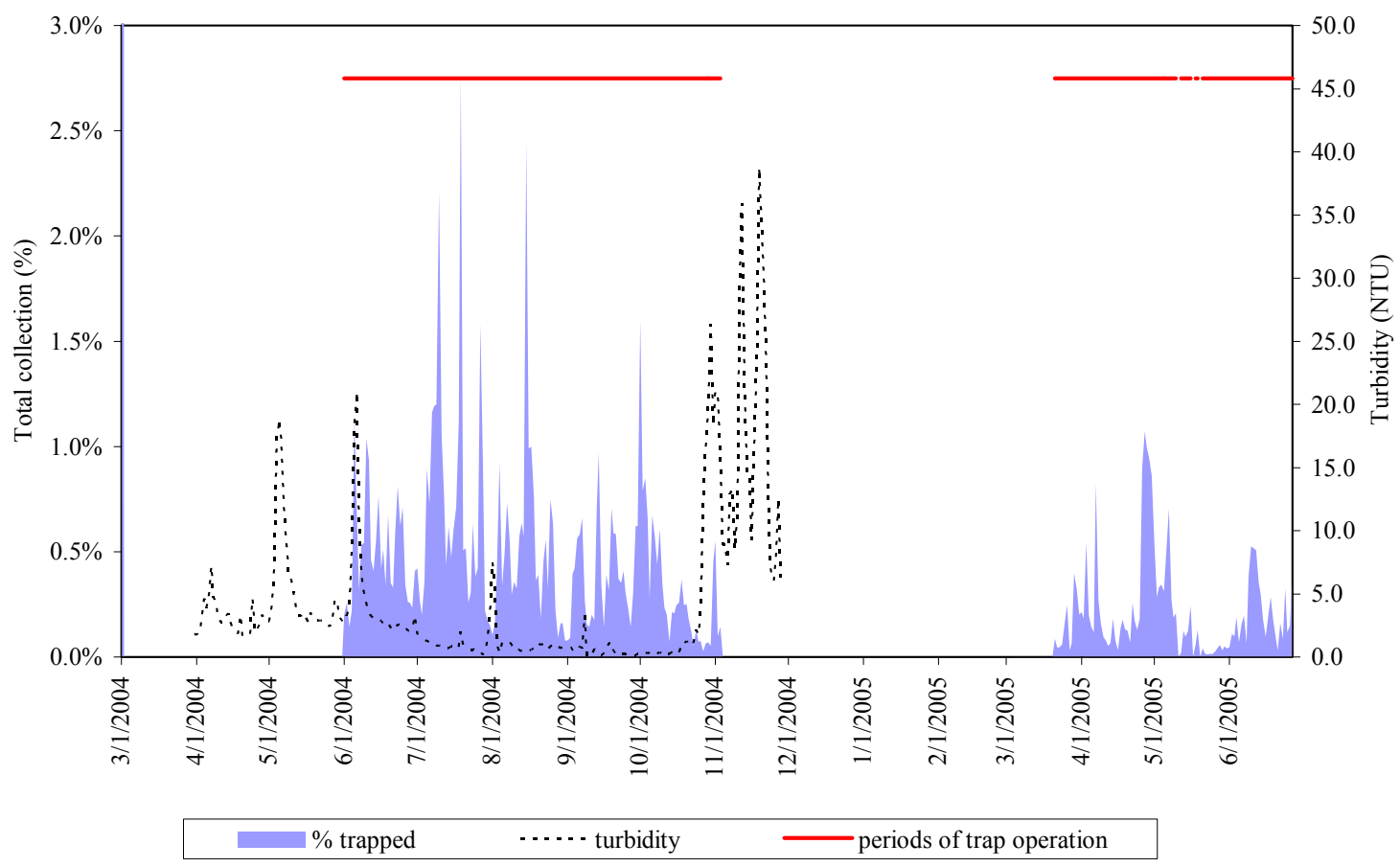

Marsh Creek Trap

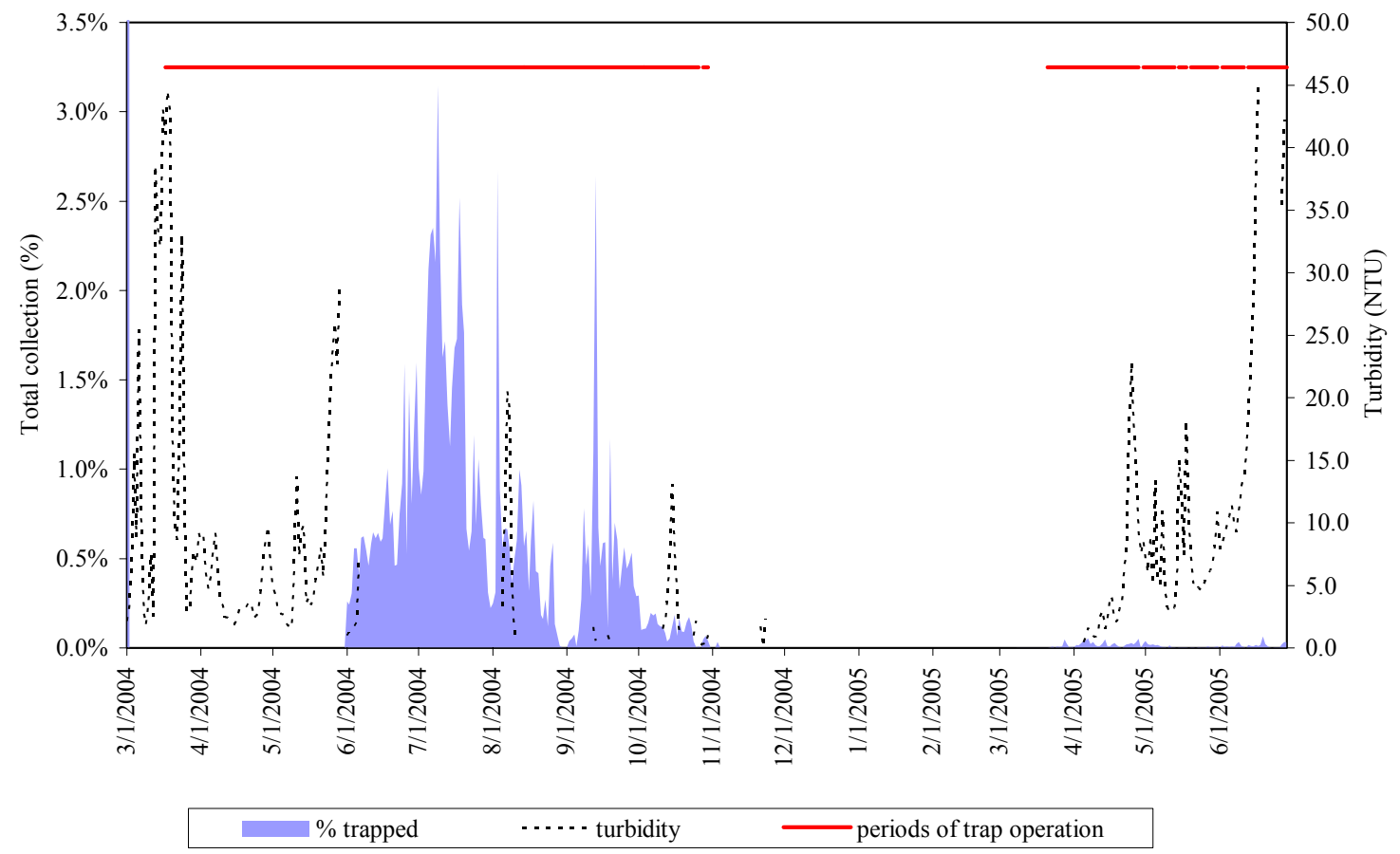

Appendix Figure 5. Daily passage of wild Chinook salmon fry, parr, and smolts at four migrant traps, expressed as percentages of total collected, and plotted against average daily turbidity collected near traps. Periods of trap operation are also shown. 
South Fork Salmon River Trap

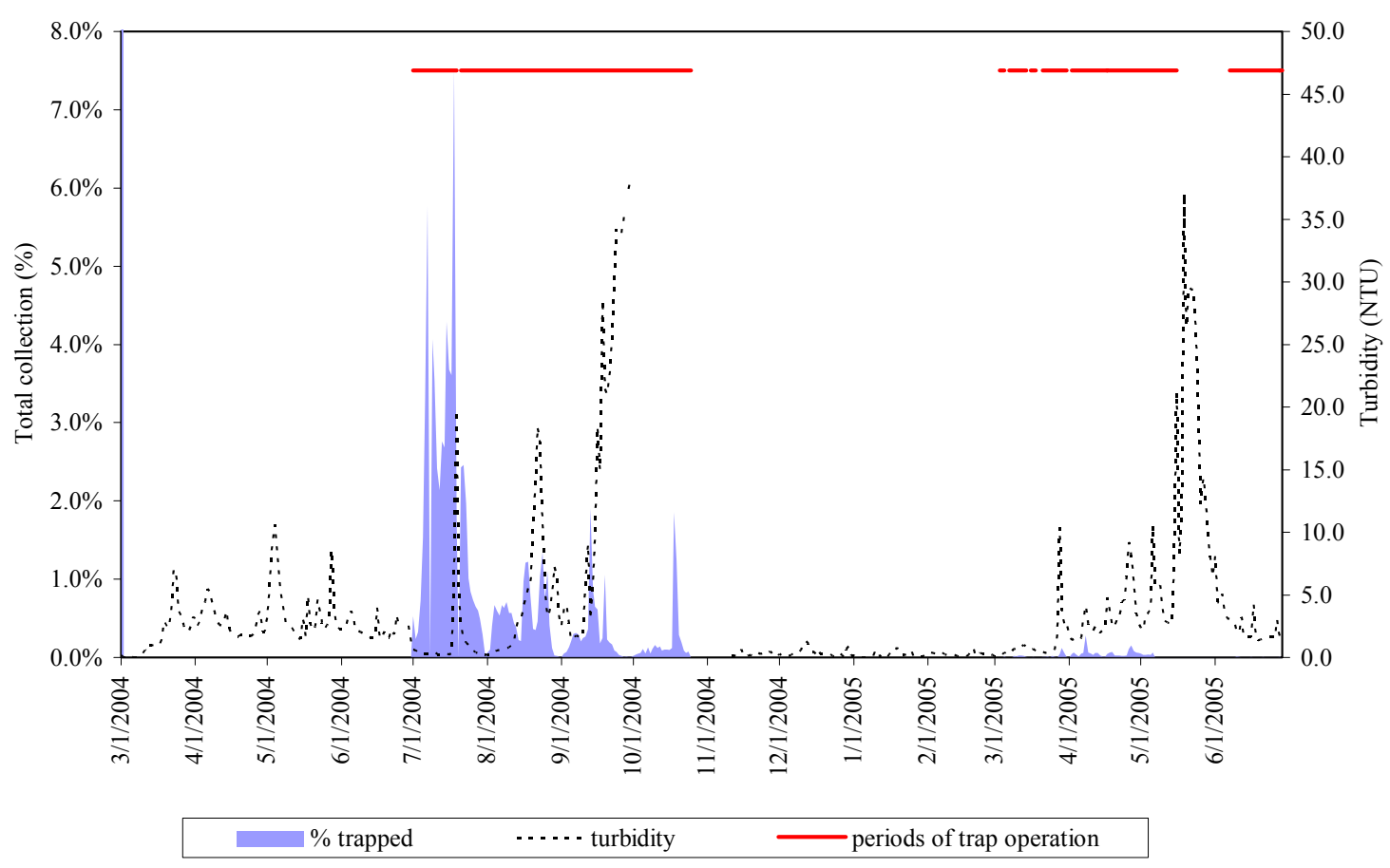

Secesh River Trap

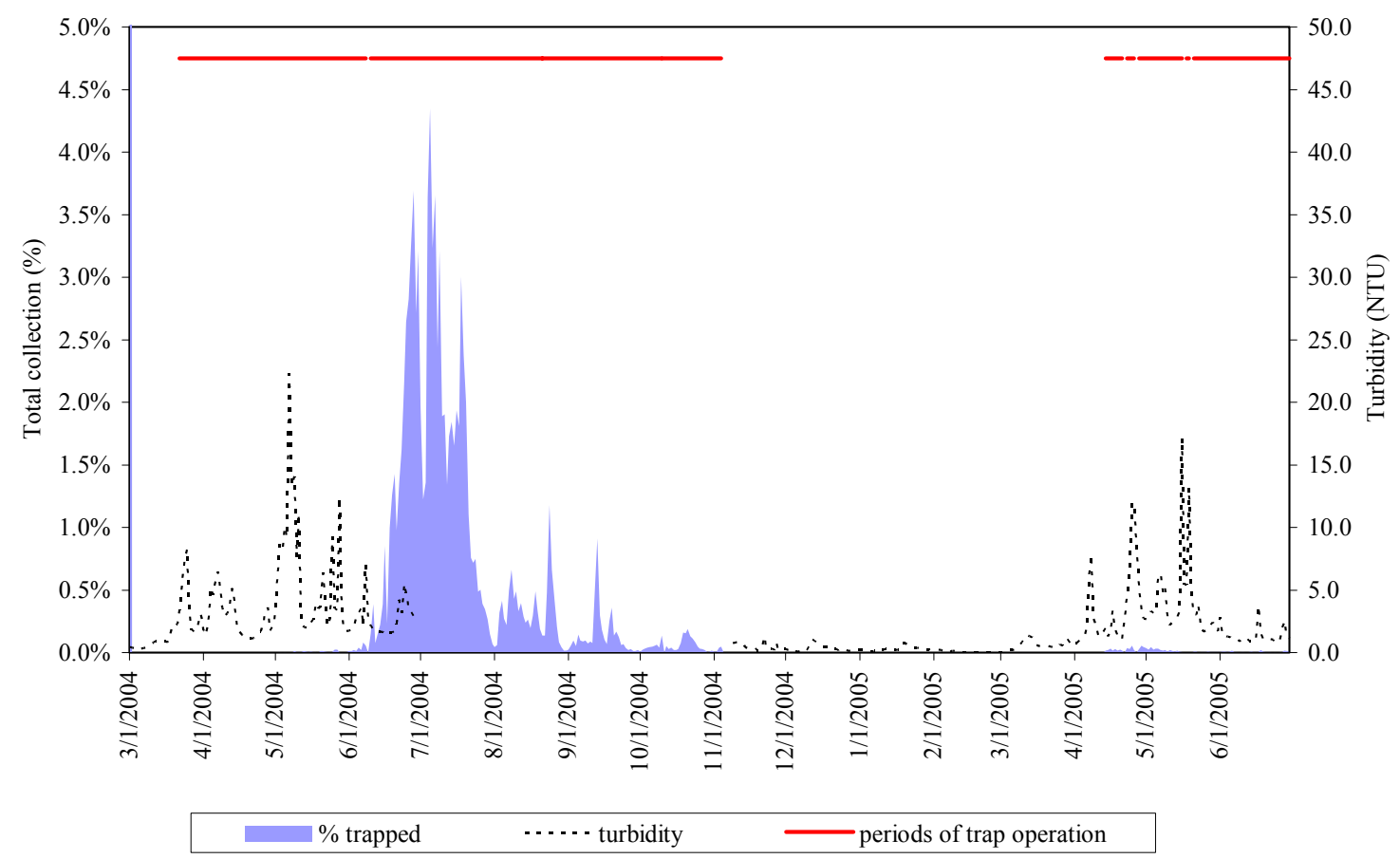

Appendix Figure 5. Continued. 
Upper Salmon River Trap

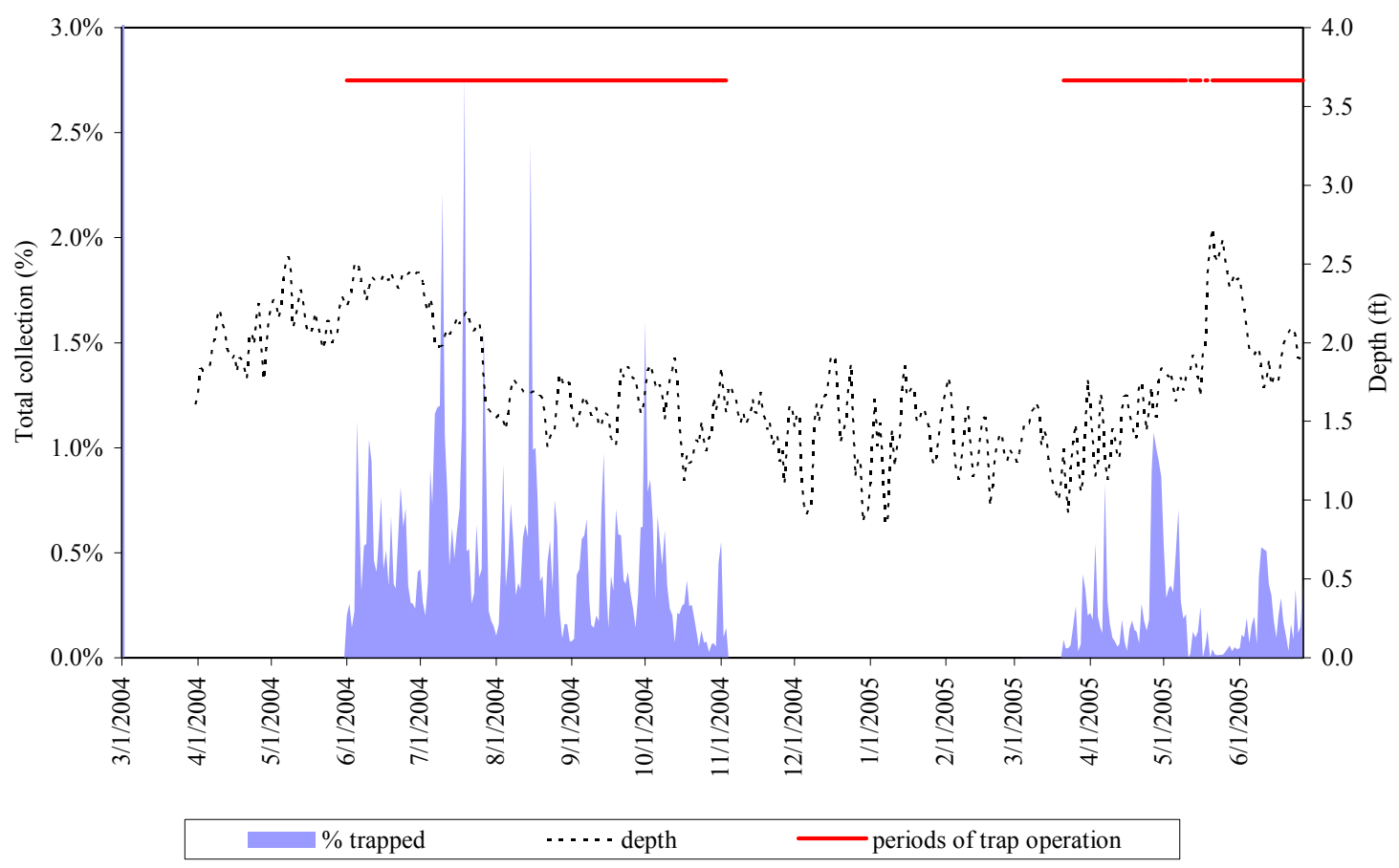

Marsh Creek Trap

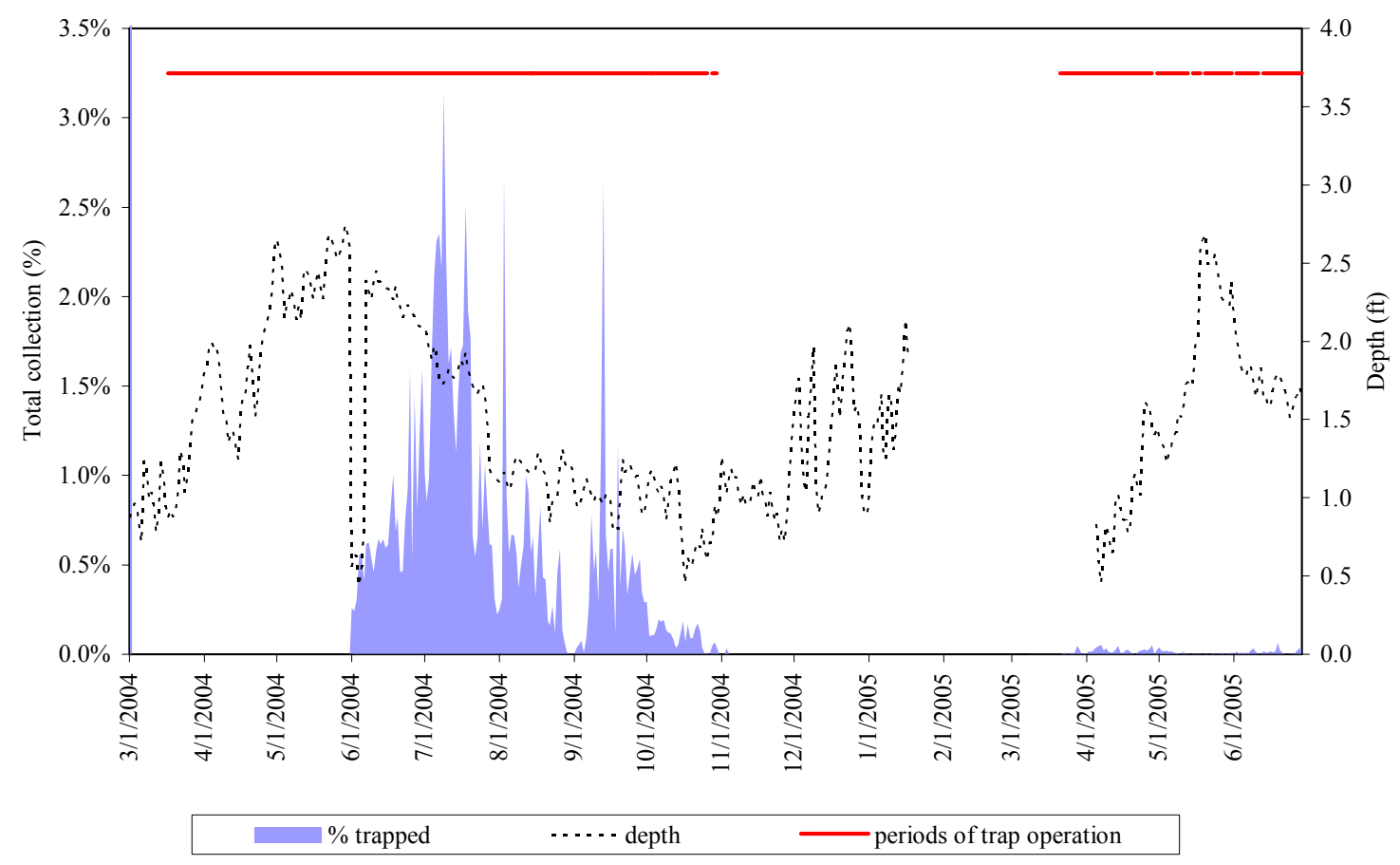

Appendix Figure 6. Daily passage of wild Chinook salmon fry, parr, and smolts at four migrant traps, expressed as percentages of total collected, and plotted against average daily depth collected near traps. Periods of trap operation are also shown. 
South Fork Salmon River Trap

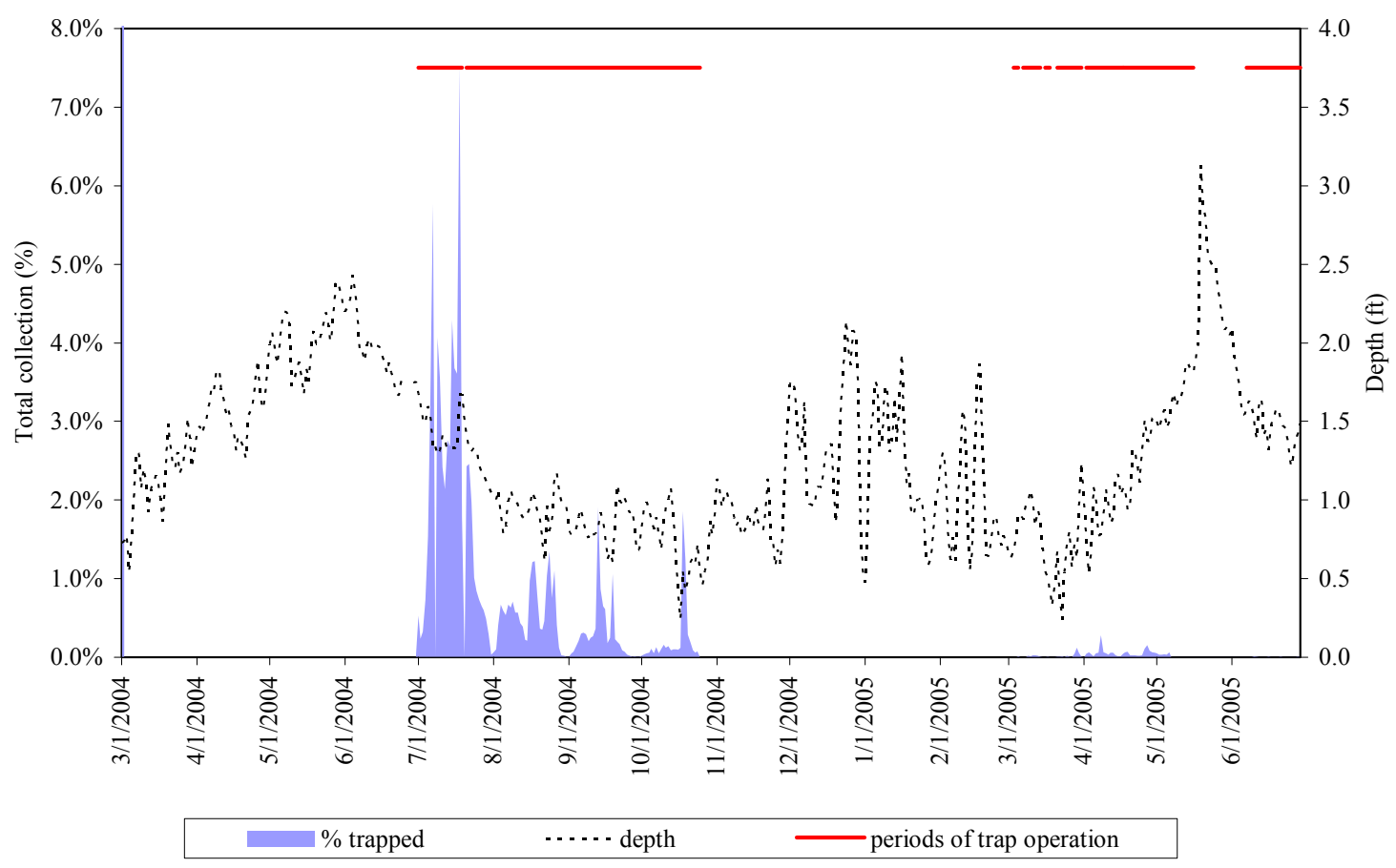

Secesh River Trap

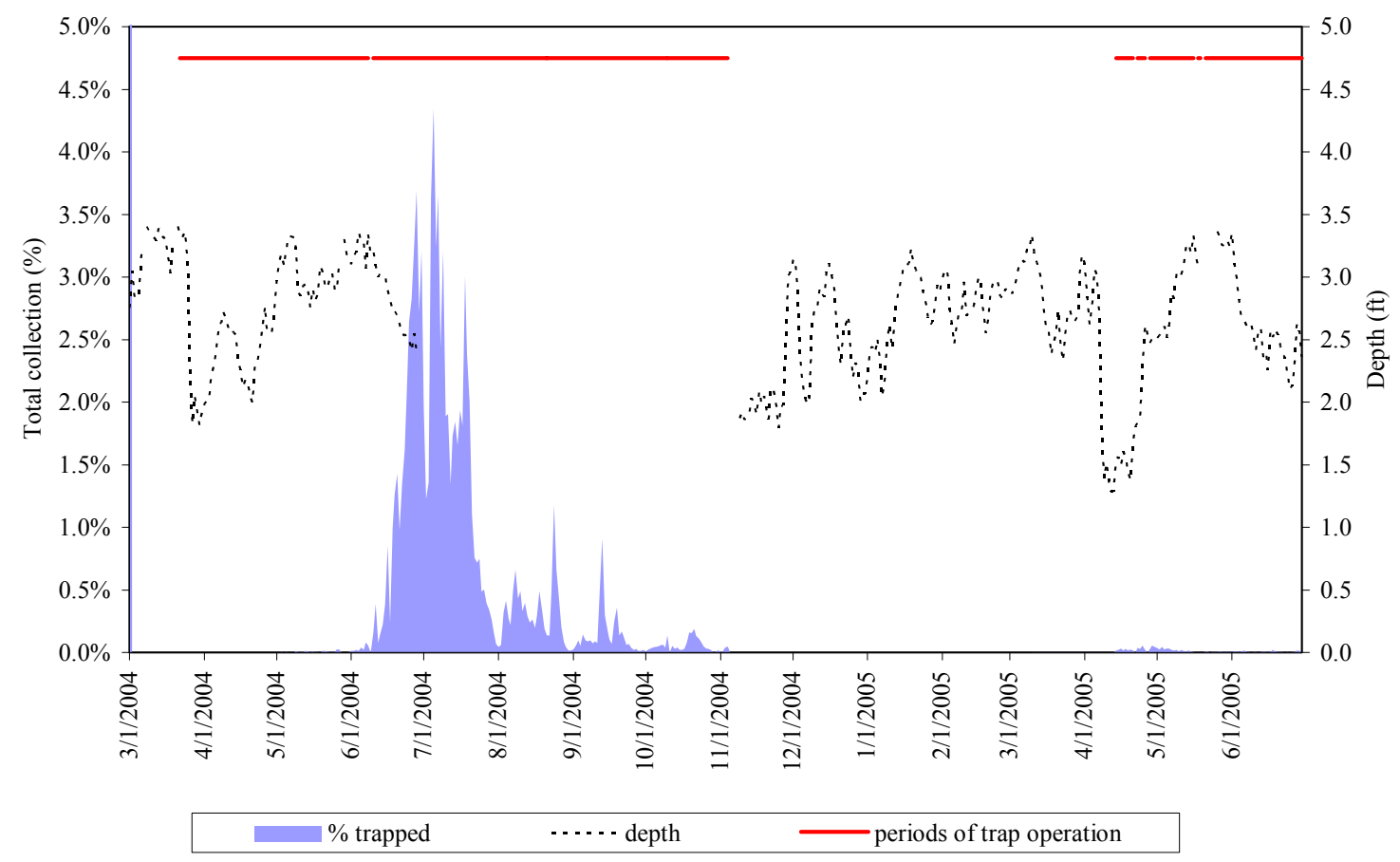

Appendix Figure 6. Continued. 


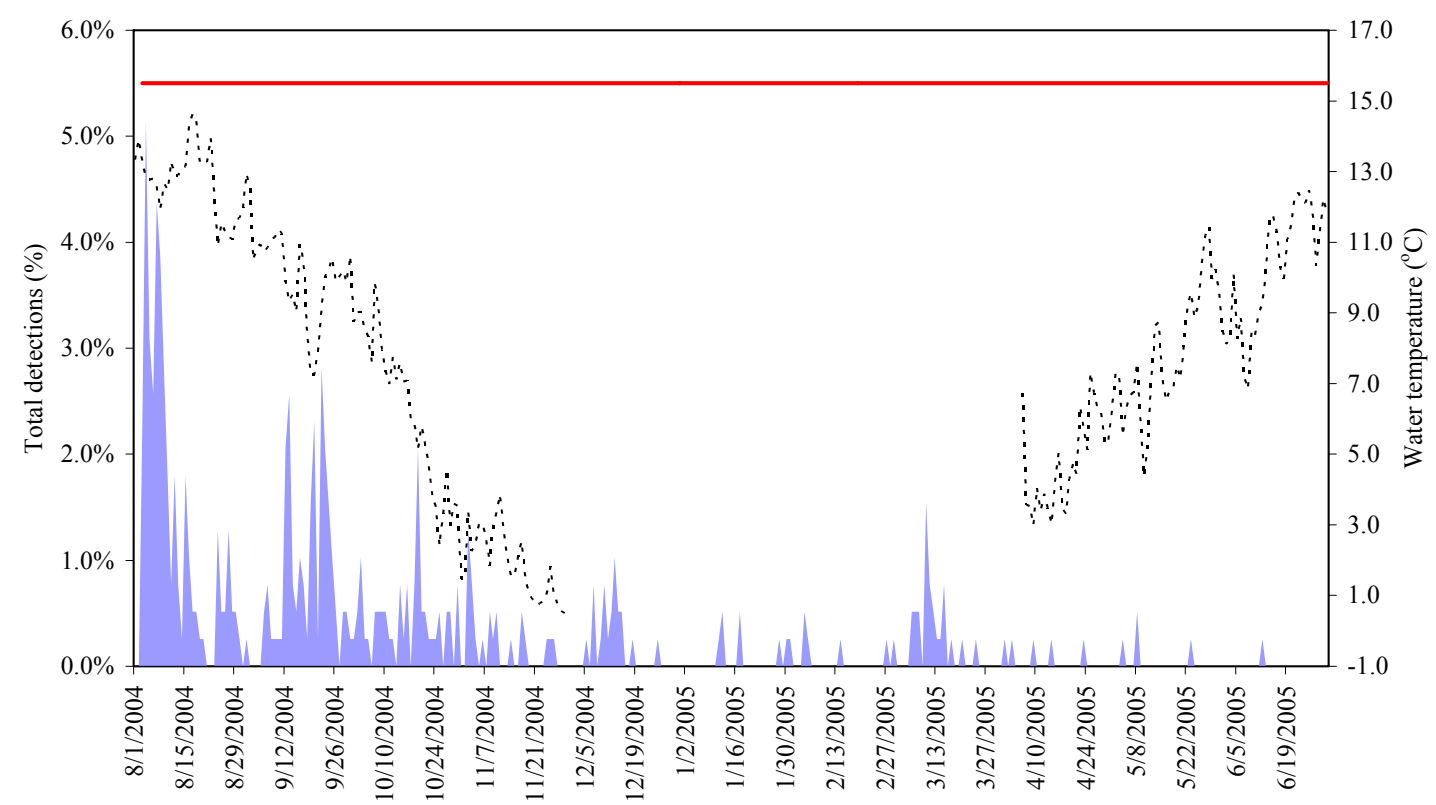

$\%$ detected $\quad$..... water temperature $\quad$ periods of detector operating

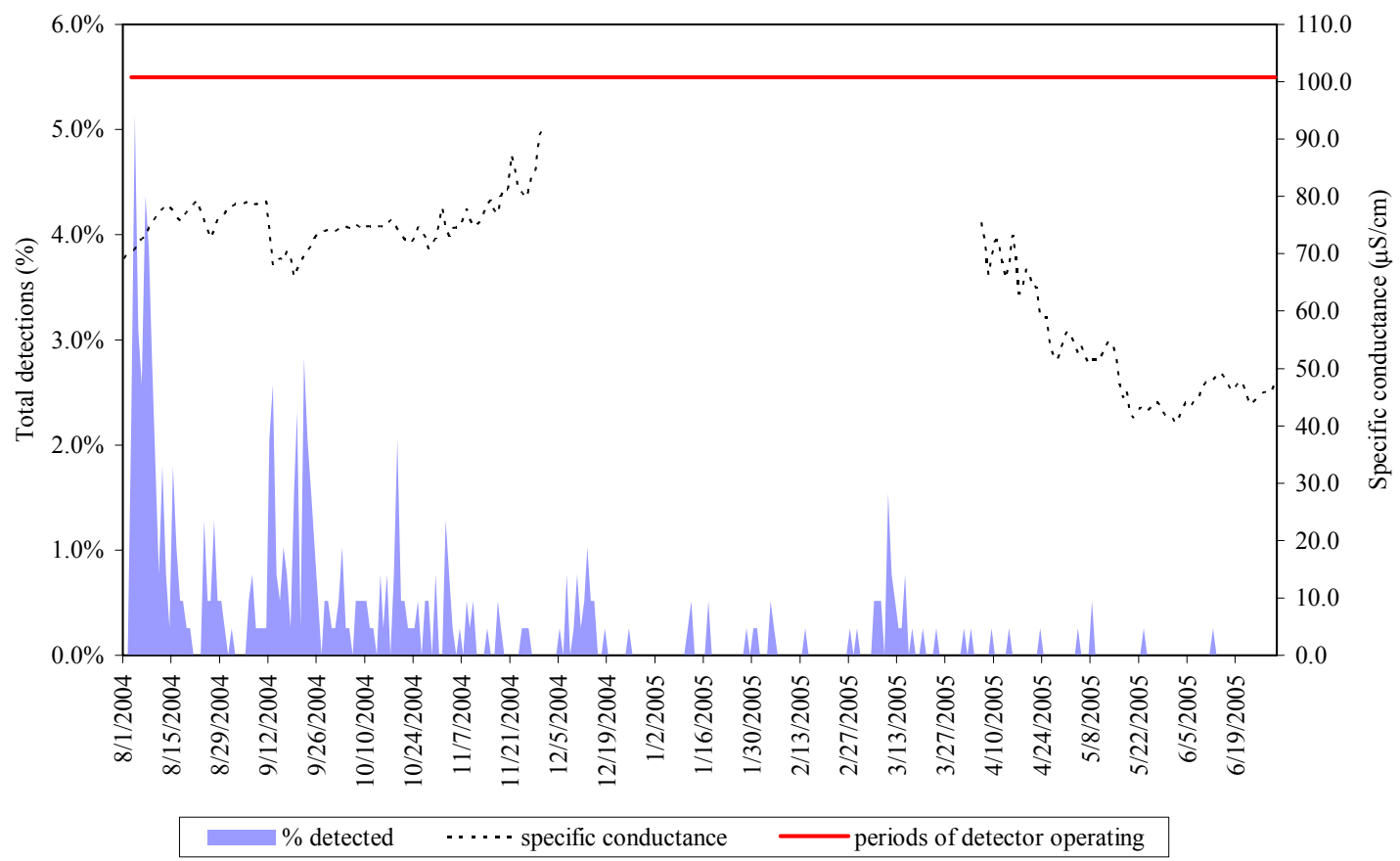

Appendix Figure 7. Combined daily PIT-tag detections of wild Chinook salmon parr at in-stream PIT-tag detectors in Valley Creek, expressed as percentages of total collected, and plotted against average daily aquatic conditions collected near the detectors. Periods of operation for the detectors are also shown. 

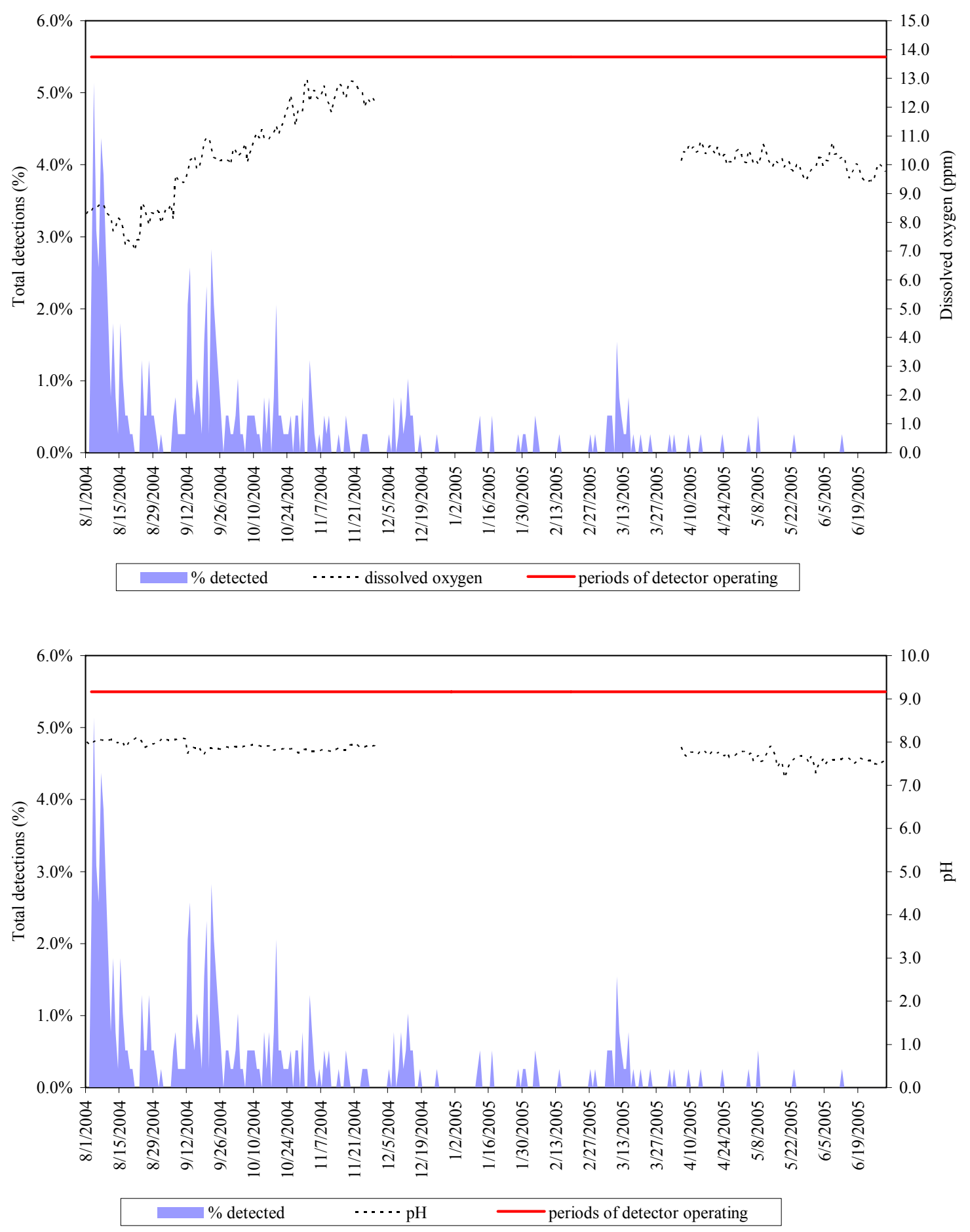

Appendix Figure 7. Continued. 

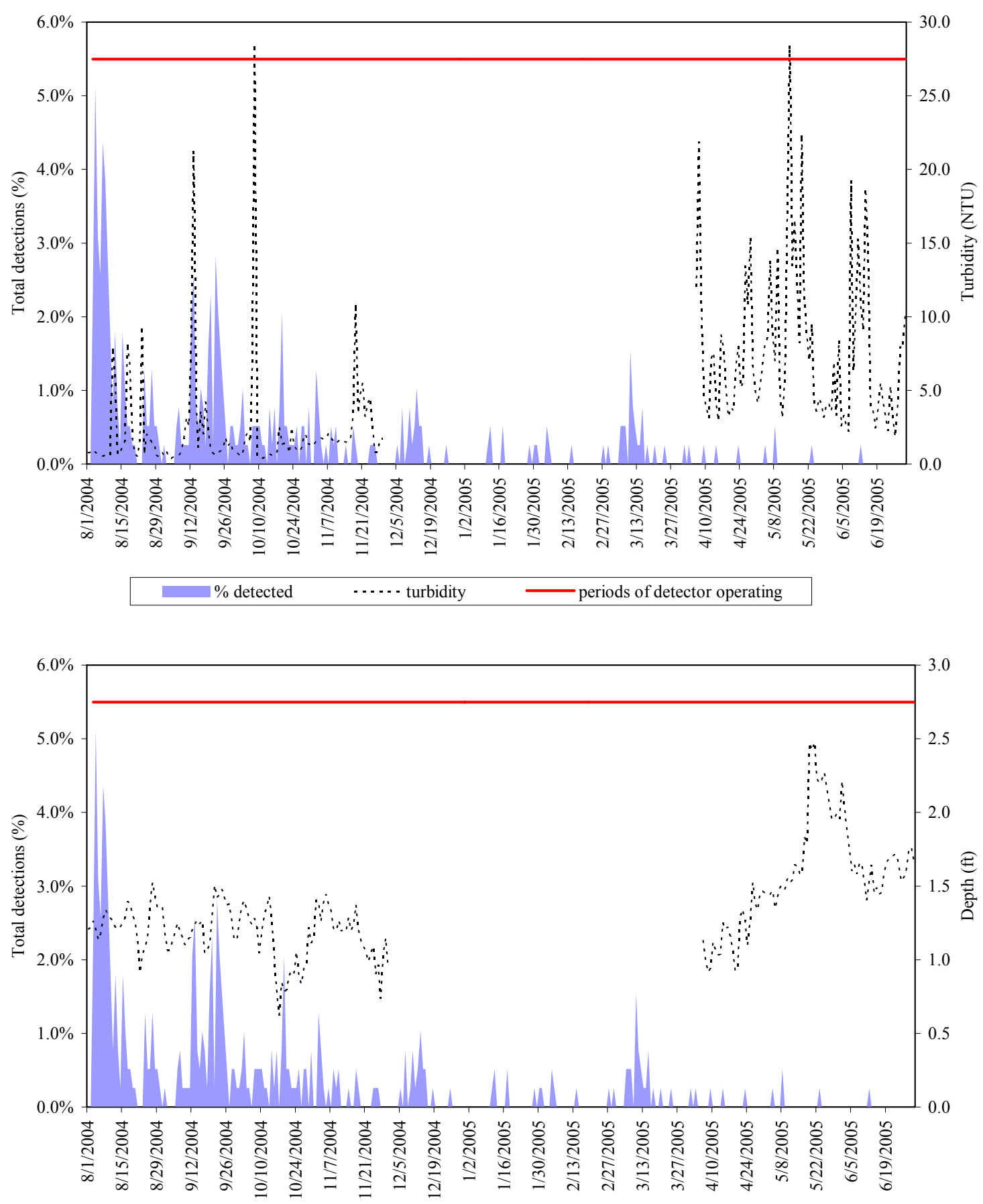

$\%$ deteced

.... depth

periods of detector operating

\section{Appendix Figure 7. Continued.}

